Prepared in Cooperation with the City of Prescott, the Town of Prescott Valley, and Salt River Project

\title{
Aquifer Storage Change and Storage Properties, 2010-2017, in the Big Chino Subbasin, Yavapai County, Arizona
}

Scientific Investigations Report 2019-5060 
Cover. Photograph looking northwest showing Big Chino Wash at the Big Chino Water Ranch in Yavapai County, Arizona, on March 7, 2019. On this date, the usually dry wash was flowing in response to snowmelt at higher elevations. (U.S. Geological Survey photograph by Jeffrey R. Kennedy.) 


\section{Aquifer Storage Change and Storage Properties, 2010-2017, in the Big Chino Subbasin, Yavapai County, Arizona}

By Jeffrey R. Kennedy, Libby M. Kahler, and Amy M. Read

Prepared in Cooperation with the City of Prescott, the Town of Prescott Valley, and Salt River Project

Scientific Investigations Report 2019-5060 


\title{
U.S. Department of the Interior DAVID BERNHARDT, Secretary
}

\author{
U.S. Geological Survey \\ James F. Reilly II, Director
}

U.S. Geological Survey, Reston, Virginia: 2019

For more information on the USGS - the Federal source for science about the Earth, its natural and living resources, natural hazards, and the environment-visit https://www.usgs.gov or call 1-888-ASK-USGS.

For an overview of USGS information products, including maps, imagery, and publications, visit https://store.usgs.gov.

Any use of trade, firm, or product names is for descriptive purposes only and does not imply endorsement by the U.S. Government.

Although this information product, for the most part, is in the public domain, it also may contain copyrighted materials as noted in the text. Permission to reproduce copyrighted items must be secured from the copyright owner.

Suggested citation:

Kennedy, J.R., Kahler, L.M., and Read, A.L., 2019, Aquifer storage change and storage properties, 2010-2017, in the Big Chino Subbasin, Yavapai County, Arizona: U.S. Geological Survey Scientific Investigations Report 2019-5060,

39 p., https://doi.org/10.3133/sir20195060.

ISSN 2328-0328 (online) 


\section{Acknowledgments}

This report builds on many years of work in cooperation with local stakeholders in Arizona, including the City of Prescott, the Town of Prescott Valley, Yavapai County, and Salt River Project. Their assistance is gratefully acknowledged. Assistance by Don Pool (U.S. Geological Survey) and Phillip McFarland and Max Gersh (both University of Arizona) in planning the study and data collection is also gratefully acknowledged. Many private landowners and the Arizona State Land Department provided access for data collection. The ongoing groundwater-level monitoring efforts of the Arizona Department of Water Resources were an invaluable contribution to this report. The Yavapai County Flood Control District and volunteer observers comprising the National Weather Service Cooperative Observer Program provided valuable rainfall data. Paulden and Prescott gravity data from the early 2000s were collected by Dan Winester, National Geodetic Survey. 


\section{Contents}

Abstract

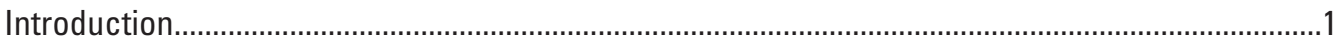

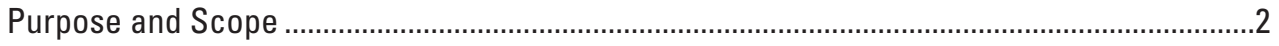

Previous Investigations ..................................................................................................

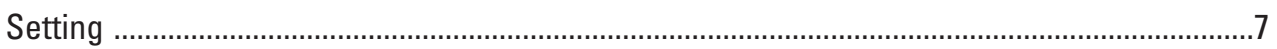

Climate

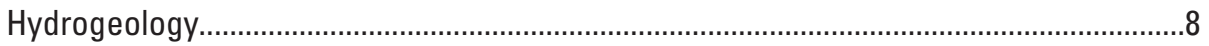

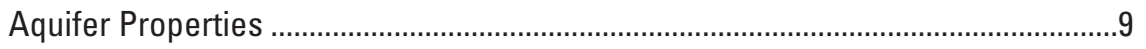

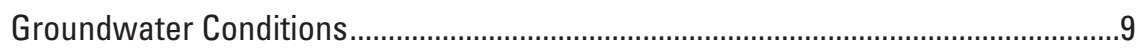

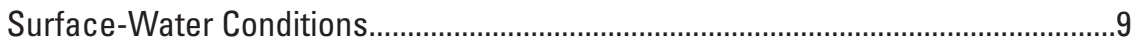

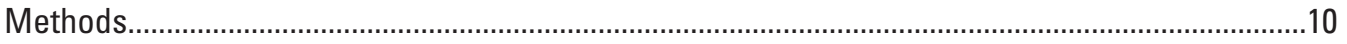

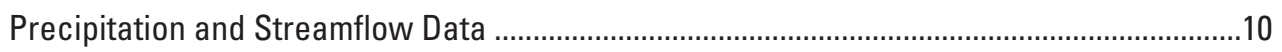

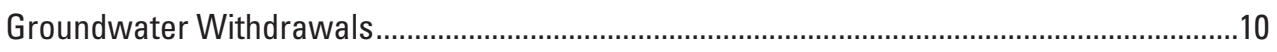

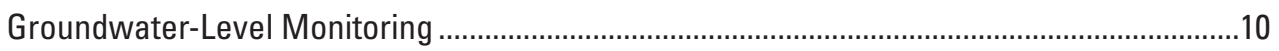

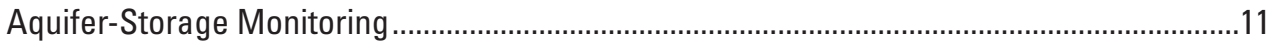

Soil-Moisture Correction ............................................................................................11

Interpreting the Gravity/Groundwater-Level Relation ...............................................12

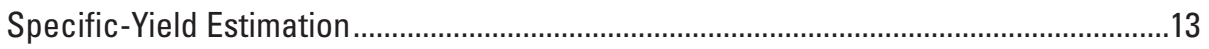

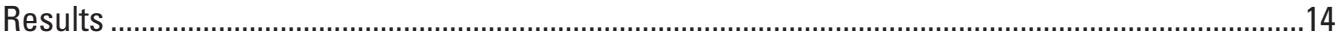

Precipitation and Streamflow Trends ...........................................................................

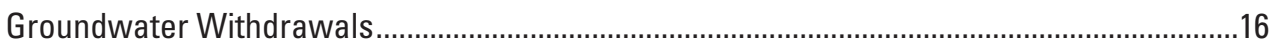

Aquifer-Storage Change and Storage Properties ...............................................................16

Williamson Valley Wash Area......................................................................................16

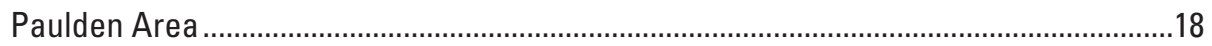

Area West of Big Chino Wash ....................................................................................22

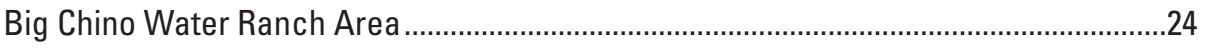

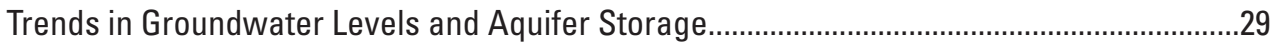

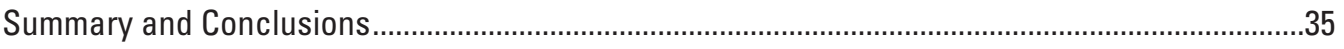

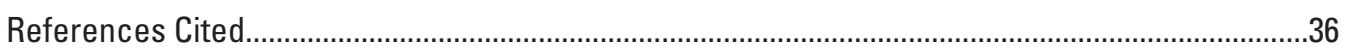

\section{Figures}

1. Map showing the location of the Big Chino and Little Chino Subbasins in north-central Arizona, including structural provinces and land ownership

2. Map showing the area of this study of the Big Chino Subbasin in north-central Arizona, including geology, faults, and major geographic features ...............................................

3. Map of the area of this study of the Big Chino Subbasin in north-central Arizona showing monitoring locations.

4. Graph of water-year time series showing root-zone soil-moisture satellite data used to correct gravity measurements from the Big Chino Subbasin in north-central Arizona for water years 2010 to 2017........................................................................................13

5. Graph showing precipitation at five stations in the Big Chino Subbasin in north-central Arizona for water years 2010 to 2017. 
6. Graphs of mean annual precipitation and monthly base flow for U.S. Geological Survey streamgaging stations Verde River near Paulden (09503700) and Williamson Valley Wash near Paulden (09502800) in the Big Chino Subbasin in north-central Arizona......15

7. Index map and hydrograph showing long-term groundwater levels at two wells in the Williamson Valley Wash area of the Big Chino Subbasin in north-central Arizona ........18

8. Graphs showing storage change and groundwater-level change (where applicable) by water year at stations 1 through 6 in the Williamson Valley Wash area of the Big Chino Subbasin in north-central Arizona.

9. Scatter-plots showing the relation between changes in groundwater storage (d; determined from repeat microgravity data) and changes in groundwater level (h) at stations 1,3, and 6 in the Williamson Valley Wash area of the Big Chino Subbasin in north-central Arizona.

10. Index map and hydrograph showing long-term groundwater levels at four wells in the Paulden area of the Big Chino Subbasin in north-central Arizona

11. Graphs showing storage change and groundwater-level change (where applicable) by water year in the Paulden area of the Big Chino Subbasin in north-central

Arizona.

12. Index map and hydrographs showing groundwater levels in the area west of Big Chino Wash of the Big Chino Subbasin in north-central Arizona.

13. Graphs showing storage change and groundwater-level change (where applicable) by water year in the area west of Big Chino Wash in the Big Chino Subbasin of northcentral Arizona

14. Index map and hydrographs showing groundwater levels in the area west of Big Chino Wash in the Big Chino Subbasin of north-central Arizona.

15. Graphs showing storage change and groundwater-level change (where applicable) by water year in the Big Chino Water Ranch area of the Big Chino Subbasin in northcentral Arizona.

16. Graph showing rapid propagation of pumping-induced groundwater-level changes at four wells in the Big Chino Water Ranch area in the Big Chino Subbasin in northcentral Arizona.

17. Map showing significant linear groundwater trends in the Big Chino Subbasin of northcentral Arizona, 2010-2017.

18. Map showing aquifer-storage trends at repeat microgravity stations in the Big Chino

Subbasin of north-central Arizona.

\section{Tables}

1. Stations used in aquifer-storage change analysis of the Big Chino Subbasin in northcentral Arizona.

2. Summary of irrigated acreage and groundwater withdrawals for the Big Chino Subbasin in north-central Arizona, calendar years 2013-2016.

3. Screened interval, specific yield, and groundwater-storage trends in the Big Chino Subbasin of north-central Arizona...

4. Groundwater wells from the Arizona Department of Water Resources (ADWR) Groundwater Site Inventory database (Arizona Department of Water Resources, 2018) that were analyzed for groundwater trends in the Big Chino Subbasin in north-central Arizona. 


\section{Conversion Factors}

U.S. customary units to International System of Units

\begin{tabular}{|c|c|c|}
\hline Multiply & By & To obtain \\
\hline \multicolumn{3}{|c|}{ Length } \\
\hline inch (in.) & 2.54 & centimeter $(\mathrm{cm})$ \\
\hline inch (in.) & 25.4 & millimeter (mm) \\
\hline foot $(\mathrm{ft})$ & 0.3048 & meter $(\mathrm{m})$ \\
\hline mile (mi) & 1.609 & kilometer $(\mathrm{km})$ \\
\hline \multicolumn{3}{|c|}{ Area } \\
\hline acre & 4,047 & square meter $\left(\mathrm{m}^{2}\right)$ \\
\hline acre & 0.4047 & hectare (ha) \\
\hline acre & 0.4047 & square hectometer $\left(\mathrm{hm}^{2}\right)$ \\
\hline acre & 0.004047 & square kilometer $\left(\mathrm{km}^{2}\right)$ \\
\hline square mile $\left(\mathrm{mi}^{2}\right)$ & 259.0 & hectare (ha) \\
\hline square mile $\left(\mathrm{mi}^{2}\right)$ & 2.590 & square kilometer $\left(\mathrm{km}^{2}\right)$ \\
\hline \multicolumn{3}{|c|}{ Volume } \\
\hline acre-foot (acre-ft) & 1,233 & cubic meter $\left(\mathrm{m}^{3}\right)$ \\
\hline acre-foot (acre-ft) & 0.001233 & cubic hectometer $\left(\mathrm{hm}^{3}\right)$ \\
\hline \multicolumn{3}{|c|}{ Flow rate } \\
\hline acre-foot per year (acre-ft/yr) & 1,233 & cubic meter per year $\left(\mathrm{m}^{3} / \mathrm{yr}\right)$ \\
\hline foot per day $(\mathrm{ft} / \mathrm{d})$ & 0.3048 & meter per day $(\mathrm{m} / \mathrm{d})$ \\
\hline foot per year (ft/yr) & 0.3048 & meter per year (m/yr) \\
\hline foot squared per day $\left(\mathrm{ft}^{2} / \mathrm{d}\right)$ & 0.09290 & meter squared per day $\left(\mathrm{m}^{2} / \mathrm{d}\right)$ \\
\hline inch per year (in/yr) & 25.4 & millimeter per year $(\mathrm{mm} / \mathrm{yr})$ \\
\hline cubic foot per second $\left(\mathrm{ft}^{3} / \mathrm{s}\right)$ & 0.02832 & cubic meter per second $\left(\mathrm{m}^{3} / \mathrm{s}\right)$ \\
\hline gallon per day (gal/d) & 0.003785 & cubic meter per day $\left(\mathrm{m}^{3} / \mathrm{d}\right)$ \\
\hline
\end{tabular}

International System of Units to U.S. customary units

\begin{tabular}{lcl}
\hline \multicolumn{1}{c}{ Multiply } & By & \multicolumn{1}{c}{ To obtain } \\
\hline \multicolumn{3}{c}{ Length } \\
\hline centimeter $(\mathrm{cm})$ & 0.3937 & inch (in.) \\
meter $(\mathrm{m})$ & 3.281 & foot $(\mathrm{ft})$ \\
kilometer $(\mathrm{km})$ & 0.6214 & mile $(\mathrm{mi})$ \\
\hline \multicolumn{3}{c}{ Volume } \\
\hline cubic meter $\left(\mathrm{m}^{3}\right)$ & 264.2 & gallon $(\mathrm{gal})$ \\
cubic meter $\left(\mathrm{m}^{3}\right)$ & 35.31 & cubic foot $\left(\mathrm{ft}^{3}\right)$ \\
\hline & \multicolumn{3}{c}{ Acceleration } \\
\hline centimeter per second squared & 0.3937 & inch per second squared $\left(\mathrm{in} / \mathrm{s}^{2}\right)$ \\
$\quad\left(\mathrm{cm} / \mathrm{s}^{2}\right)$ & \multicolumn{3}{c}{ nanometer per second squared $\left(\mathrm{nm} / \mathrm{s}^{2}\right)$} \\
microgal $(\mu \mathrm{Gal})$ & 10 & Feet per second squared $\left(\mathrm{ft} / \mathrm{s}^{2}\right)$ \\
microgal $(\mu \mathrm{Gal})$ & $0.328 \times 10^{-9}$ &
\end{tabular}




\section{Datum}

Vertical coordinate information is referenced to the North American Vertical Datum of 1988 (NAVD 88).

Horizontal coordinate information is referenced to the North American Datum of 1983

(NAD 83).

\section{Supplemental Information}

Different naming conventions are used for the gravity, long-term groundwater level, and groundwater-level trend sites. Repeat microgravity stations used to measure aquifer-storage change are assigned a numeric ID between 1 and 32, used in the discussion, on maps, and in tables 1 and 3. Each gravity station also has a site name, which is most often but not always the well number assigned by the Arizona Department of Water Resources (ADWR) (for example, B-18-02 20DBB). Wells collocated with gravity stations also have a U.S. Geological Survey or ADWR 15-digit site identifier; the well number and site identifier are provided in table 1 but are generally not used in the report or on maps. Wells with long-term groundwater levels referenced in the discussion are referenced by their well number (for example, B-16-04 27BCB). Finally, groundwater sites from the ADWR database used in the groundwater-level trend analysis are referenced by a numeric ID between $A 1$ and $A 73$. The corresponding site identifiers are provided in table 4 . Some sites may have station numbers under both the gravity station naming convention and groundwater-level trend site naming convention.

ARIZONA WELL-NUMBERING SYSTEM
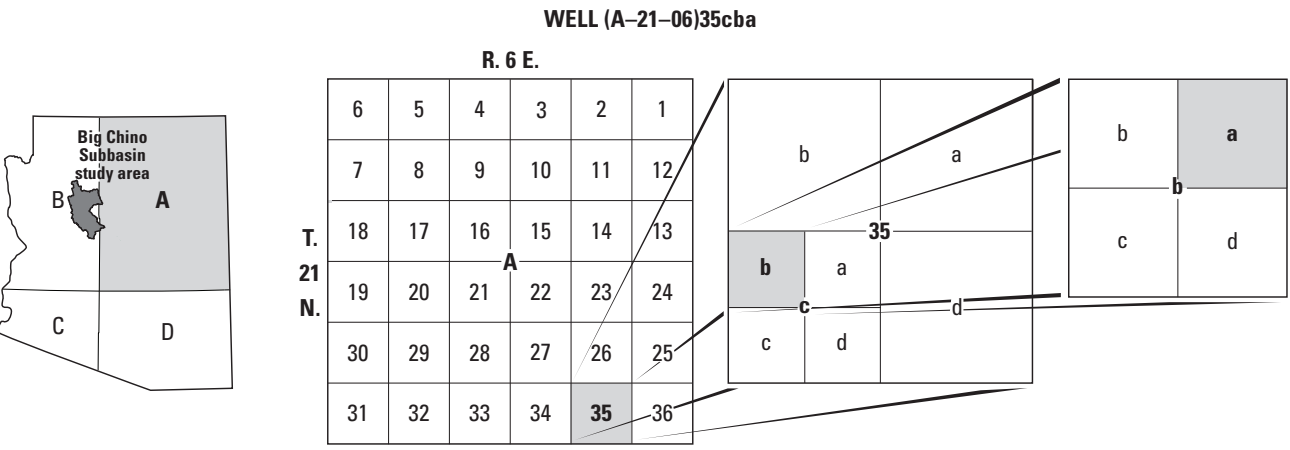

Quadrant A, township 21 north, range 6 east, section 35,

quarter section $\mathbf{c}$, quarter section $\mathbf{b}$, quarter section a

The well numbers used by the U.S. Geological Survey in Arizona are in accordance with the Bureau of Land Management's system of land subdivision. The land survey in Arizona is based on the Gila and Salt River meridian and base line, which divide the State into four quadrants and are designated by capital letters A, B, C, and D in a counterclockwise direction beginning in the northeast quarter. The first digit of a well number indicates the township, the second the range, and the third the section in which the well is situated. The lowercase letters a, b, c, and d after the section number indicate the well location within the section. The first letter denotes a particular 160-acre tract, the second the 40-acre tract and the third the 10-acre tract. These letters also are assigned in a counterclockwise direction beginning in the northeast quarter. If the location is known within the 10 -acre tract, three lowercase letters are shown in the well number. Where more than one well is within a 10-acre tract, consecutive numbers beginning with 1 are added as suffixes. In the example shown, well number (A-21-06)35cba designates the well as being in the northeast quarter, northwest quarter, southwest quarter, section 35, township 21 north, and range 6 east (NE1/4, NW1/4, SW1/4, sec. 35, T. 21 N., R. 6 E.). 


\section{Abbreviations}

ADWR Arizona Department of Water Resources

ASCAT Advanced Scatterometer instrument on the European Space Agency Metop-A and Metop-B satellites

BCWR Big Chino Water Ranch

NASA National Aeronautics and Space Administration

NOAA National Oceanic and Atmospheric Administration

NSIDC National Snow and Ice Data Center

SMAP National Aeronautics and Space Administration, National Snow and Ice Data Center, Soil Moisture Active Passive (SMAP) Surface and Root Zone Soil Moisture Analysis Update

USGS U.S. Geological Survey 


\title{
Aquifer Storage Change and Storage Properties, 2010-2017, in the Big Chino Subbasin, Yavapai County, Arizona
}

\author{
By Jeffrey R. Kennedy, Libby M. Kahler, and Amy L. Read
}

\section{Abstract}

The Big Chino Subbasin is a groundwater basin that includes the Verde River headwaters in Yavapai County in north-central Arizona. Groundwater in the southern part of the subbasin is found primarily in the Big Chino and Williamson Valleys. The former is a potential municipal water source for growing communities in Yavapai County, particularly groundwater from the Big Chino Water Ranch, about 15 miles northwest of the community of Paulden. Groundwater in the Big Chino Valley discharges to wells (by pumping), by evapotranspiration, and to the upper Verde River springs, which form the headwaters of the Verde River. Groundwater also discharges to short perennial reaches of Williamson Valley Wash, Walnut Creek, and a small number of small, ungaged springs and seeps. To monitor changes in groundwater storage and to identify aquifer-storage properties, a network of repeat microgravity stations and groundwater-level monitoring stations was established in the Big Chino and Williamson Valleys in 2010.

Small decreases in groundwater storage were observed throughout the study area from 2010 to 2017 . Annual groundwater withdrawals for agricultural use varied between 2,800 and 4,000 acre-ft between 2013 and 2016, with an additional amount, probably less than 1,000 acre-ft, withdrawn for domestic use, primarily in the Paulden and Williamson Valley Wash areas. No local recharge events from sustained rainfall were observed during 2010 to 2017, and base-flow discharge in the Verde River near Paulden and Williamson Valley Wash near Paulden was consistently below the long-term average (for years 1964 to 2017 and 1966 to 2017, respectively) at each site. Relations between groundwater-level changes and aquifer-storage changes (determined from repeat microgravity data) indicate monitoring wells are representative primarily of semiconfined aquifer conditions in the Paulden area, the area west of Big Chino Wash, and the Big Chino Water Ranch area. Unconfined aquifer conditions are monitored in the Williamson Valley Wash area and at two sites in the Paulden area. Specific yield was estimated at five wells and ranged between 0.04 and 0.34 , with a median value of 0.23 .

Negative groundwater-level trends (increasing depth to water) were observed between 2010 and 2017 at all sites where trends were identified using the Mann-Kendall trend test, except for the northernmost reaches of Big Chino Wash within and to the north of the Big Chino Water Ranch. Groundwater storage trends were negative at all sites where trends were identified except for one site in the foothills of the Santa Maria mountains west of Big Chino Wash. Declining storage in the Big Chino Water Ranch area, where water levels show no trend or are increasing, are likely the result of drying conditions in the unsaturated zone and (or) aquifers located above the aquifer(s) monitored by wells.

\section{Introduction}

The Big Chino Subbasin (fig. 1) is a groundwater basin that includes the Verde River headwaters in Yavapai County in north-central Arizona. The southern part of the subbasin, the focus of this report, consists of alluvial basins in the Big Chino and Williamson Valleys bounded by sedimentary and igneous rocks, with interbedded volcanic units (fig. 2). The Verde River, one of the major perennial rivers in Arizona, emanates from the subbasin. Verde River base flow relies on groundwater discharge, including discharge from the upper Verde River springs, believed to be a discharge zone of groundwater from basin-fill and Paleozoic carbonate aquifers in the Big Chino Subbasin (Wirt and others, 2005; Blasch and others, 2006). Ephemeral streams in the subbasin provide some recharge to the groundwater system, especially in years with high precipitation; runoff and, therefore, ephemeral-stream recharge is near zero in dry years. Recharge also occurs at higher elevations in the surrounding mountain ranges, but land-surface recharge at the basin floor is likely minimal, owing to low precipitation and high evapotranspiration demand. Communities south of the Verde River headwaters, including Prescott and Prescott Valley, are considering augmenting their water supplies by using groundwater withdrawals from the Big Chino Subbasin. Downstream users of Verde River flows, including greater Phoenix water provider Salt River Project, are concerned that Big Chino Subbasin groundwater withdrawals will eventually reduce the flow in the Verde River and their water availability. 


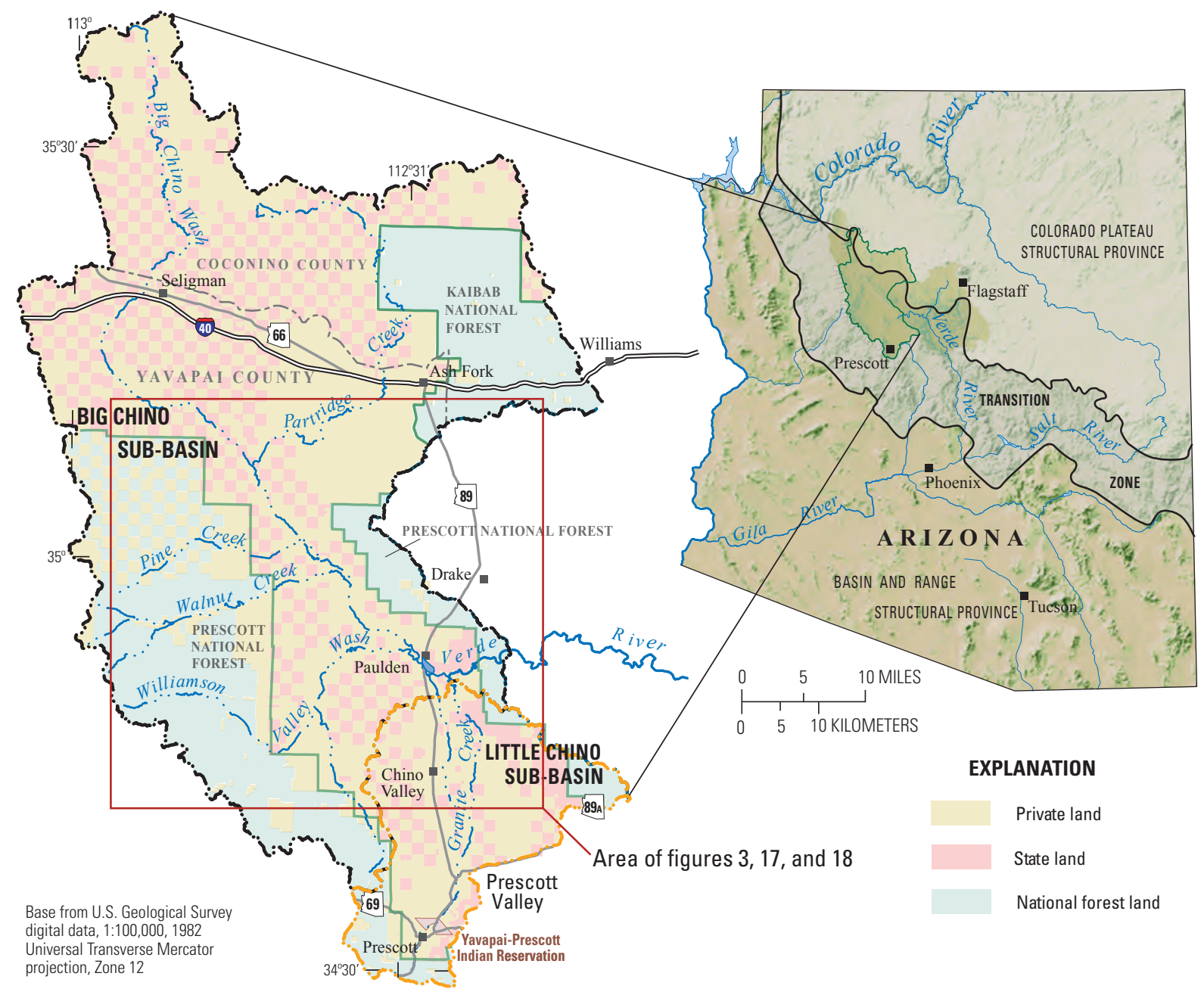

Figure 1. Map showing the location of the Big Chino and Little Chino Subbasins in north-central Arizona, including structural provinces and land ownership.

\section{Purpose and Scope}

The purpose of this report is to describe groundwaterstorage and groundwater-level trends, aquifer confining conditions, and aquifer storage properties in the Big Chino and Williamson Valley parts of the Big Chino Subbasin, Yavapai County, Arizona from water years 2010 to 2017 (water years begin on October 1 of the previous year, so water year 2010 covers October 1, 2009, through September 30, 2010). The groundwater-storage trends record current conditions under the current minimal pumping regime in the study area and will be useful for comparison to future trends if the amount of pumping changes in the future. Aquifer confining conditions and specific-yield estimates presented in the report may be useful for improving groundwater-flow models.

This report summarizes aquifer-storage change, determined from repeat microgravity measurements, from 2010 to 2017 at 32 stations (not all stations were occupied during the entire period) (see fig. 3 for station locations). Storage-change trends were estimated from repeat microgravity measurements at 16 stations and specific yield estimated at 5 stations with collocated monitoring wells. Repeat-microgravity data are published in an accompanying data release (Kennedy and others, 2019). Groundwater-level trends are presented for 73 wells. Groundwater data were collected by the U.S. Geological Survey (USGS) and the Arizona Department of Water Resources (ADWR). Collocated groundwater-level and repeatmicrogravity measurements were used to estimate confining conditions and specific yield at locations determined to have unconfined aquifer storage.

\section{Previous Investigations}

Although historical data are sparse, the data-collection effort in the Big Chino Subbasin has grown steadily since the 1970s. The first water-level contour map of the Big Chino Subbasin was created by Wallace and Laney (1976) and later updated by Schwab (1995). Wallace and Laney (1976) noted a range of changes in groundwater levels in different parts of the subbasin, including little to no change in the Paulden area from 1952 to 1975, declines from less than a foot to 23 feet (ft) in the central part of Big Chino Valley from 1973 to 1975, 


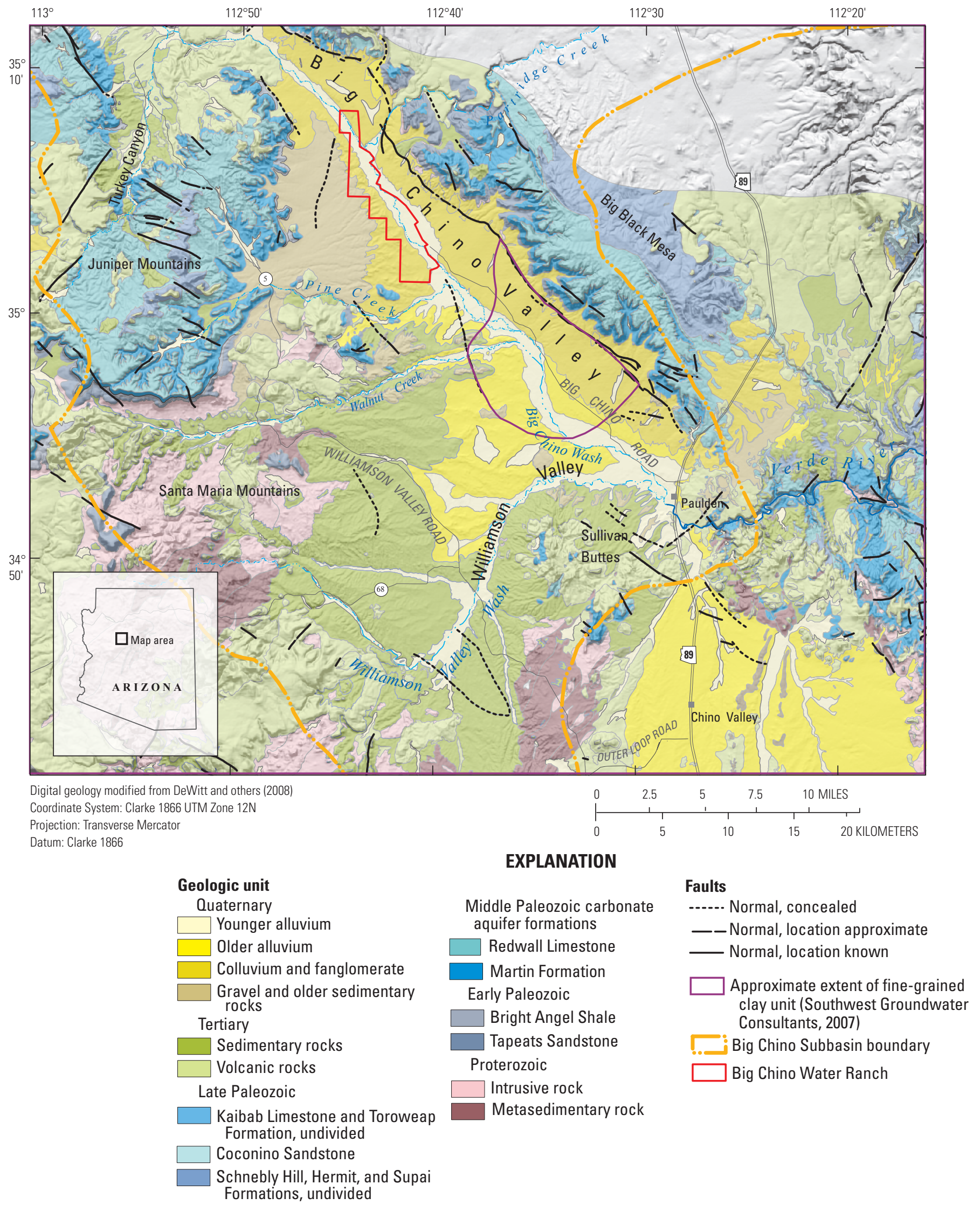

Figure 2. Map showing the area of this study of the Big Chino Subbasin in north-central Arizona, including geology, faults, and major geographic features. 


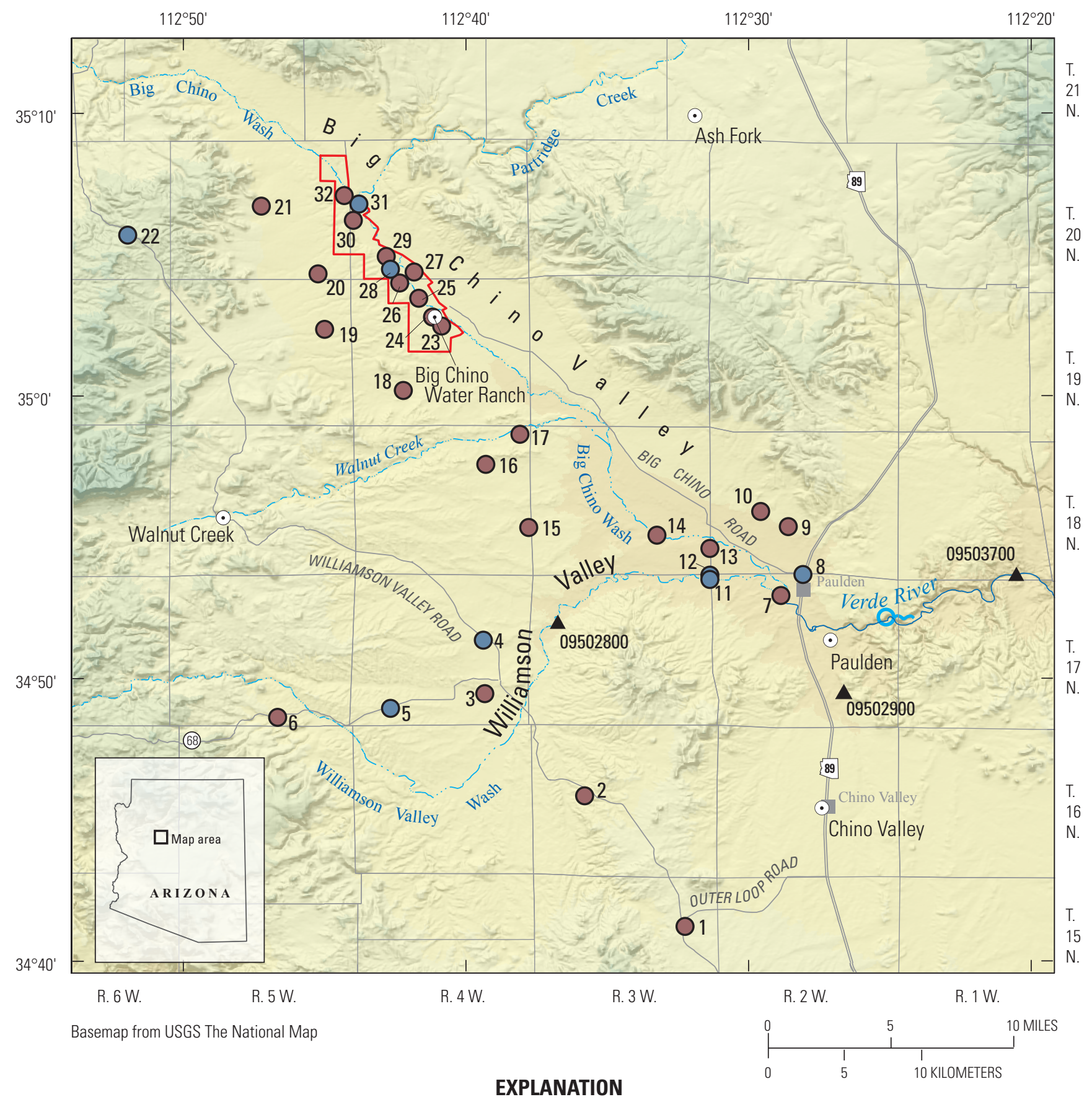

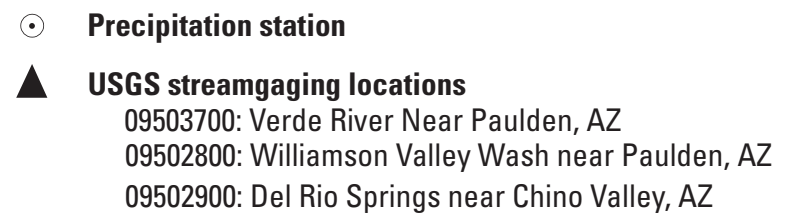

Big Chino Water Ranch

Figure 3. Map of the area of this study of the Big Chino Subbasin in north-central Arizona showing monitoring locations. Numbers correspond to repeat microgravity stations listed in table 1. See figure 1 for location of map. 
and increases in groundwater level in the Williamson Valley from the mid-1960s to 1975. Reported groundwater pumpage in lower Big Chino Valley was 20,000 acre-feet per year (acre-ft/yr) from 1950 (the first year of data) to 1966 and was between 9,000 and 11,000 acre-ft/yr from 1967 to 1974. Groundwater pumping in Williamson Valley was 2,000 acrefeet (acre-ft) annually from 1950 to 1974. By 1985, groundwater pumping in the subbasin had decreased to approximately 5,000 acre-ft/yr (including 2,000 acre-ft/yr in the Williamson Valley area; Wilson, 1991). Between 1975 and 1992, groundwater levels in most wells showed "little to virtually no change" (Schwab, 1995), although water-level rises were observed in some wells near the center of the valley, attributed to reduced pumping for irrigation.
Several previous investigations have covered the Big Chino Subbasin. Aquifer tests and other investigations for possible Prescott supply wells were carried out by Water Resources Associates (1990). They noted productive groundwater wells in alluvial, volcanic, and bedrock (Paleozoic limestone) aquifers, along with a thick clay unit in the center of Big Chino Valley (fig. 2). Heterogeneity was noted by Ewing and others (1994) during a pumping test at well B-19-04 03BCD, 1 mile eastnortheast of well B-19-04 04CAC (fig. 3 and table 1; see Supplemental Information in the front of this report for explanation of well-numbering conventions). Out of four monitoring wells, one well, 54 feet (ft) from the pumped well, had a transmissivity and storativity representative of the "local" aquifer of 21,600 foot squared per day $\left(\mathrm{ft}^{2} / \mathrm{d}\right)$ and 0.3 , respectively. Three other

Table 1. Stations used in aquifer-storage change analysis of the Big Chino Subbasin in north-central Arizona.

[NA, repeat microgravity station without collocated monitoring well; NAD83(2011), North American Datum of 1983 (2011); NAVD88, North American Vertical Datum of 1988; AZ014; Arizona Department of Water Resources; USGS, U.S. Geological Survey]

\begin{tabular}{|c|c|c|c|c|c|}
\hline \multirow{2}{*}{$\begin{array}{l}\text { Station } \\
\text { number }\end{array}$} & \multirow{2}{*}{ Station ID } & \multirow{2}{*}{ Agency code and site number ${ }^{3}$} & \multicolumn{3}{|c|}{$\begin{array}{c}\text { Gravity-station coordinate } \\
\text { [NAD83(2011) Epoch 2010.00, NAVD88/GEOID12B] }\end{array}$} \\
\hline & & & $\begin{array}{l}\text { Latitude, } \\
\text { north }\end{array}$ & $\begin{array}{l}\text { Longitude, } \\
\text { west }\end{array}$ & $\begin{array}{l}\text { Elevation, } \\
\text { in feet }\end{array}$ \\
\hline \multicolumn{6}{|c|}{ Williamson Valley Wash area } \\
\hline 1 & B-15-03 11DDB & AZ014 344122112322201 & $34.68982^{2}$ & 112.53846 & 5,072 \\
\hline 2 & B-16-03 17DAD & $344604112354301^{1}$ & $34.76817^{2}$ & 112.59558 & 4,836 \\
\hline 3 & B-17-04 26DBC & USGS 344930112391901 & 34.825425 & 112.655494 & $4,639.41$ \\
\hline 4 & $\begin{array}{l}\text { WILLIAMSON } \\
\text { VALLEY ROAD }\end{array}$ & NA & 34.856974 & 112.656354 & $4,600.12$ \\
\hline 5 & CAMP WOOD 2 & NA & 34.816747 & 112.711087 & $4,798.16$ \\
\hline 6 & B-17-05 34DBA1 & AZ014 344841112463701 & 34.811444 & 112.777641 & $4,864.55$ \\
\hline \multicolumn{6}{|c|}{ Paulden area } \\
\hline 7 & B-17-02 04DBC1 PZ1 & AZ014 345300112283701 & 34.882353 & 112.478682 & $4,365.25$ \\
\hline 7 & B-17-02 04DBC1 PZ2 & AZ014 345300112283702 & 34.882353 & 112.478682 & $4,365.25$ \\
\hline 7 & B-17-02 04DBC1 PZ3 & AZ014 345300112283703 & 34.882353 & 112.478682 & $4,365.25$ \\
\hline 8 & PAULDEN AA & NA & $34.89570^{2}$ & $112.46788^{2}$ & 4,403 \\
\hline 9 & B-18-02 28ABA & USGS 345528112283201 & 34.923927 & 112.476498 & $4,493.06$ \\
\hline 10 & B-18-02 20DBB & USGS 345557112294501 & 34.931629 & 112.496959 & $4,495.87$ \\
\hline 11 & $\begin{array}{l}\text { CHINO VALLEY } \\
\text { SOUTH }\end{array}$ & NA & 34.892773 & 112.522753 & $4,388.85$ \\
\hline 12 & B-17-02 06BBB & USGS 345338112311801 & 34.894577 & 112.522857 & $4,390.42$ \\
\hline
\end{tabular}


Table 1. Stations used in aquifer-storage change analysis of the Big Chino Subbasin in north-central Arizona.-Continued

[NA, repeat microgravity station without collocated monitoring well; NAD83(2011), North American Datum of 1983 (2011); NAVD88, North American Vertical Datum of 1988; AZ014; Arizona Department of Water Resources; USGS, U.S. Geological Survey]

\begin{tabular}{|c|c|c|c|c|c|}
\hline \multirow{2}{*}{$\begin{array}{l}\text { Station } \\
\text { number }\end{array}$} & \multirow{2}{*}{ Station ID } & \multirow{2}{*}{ Agency code and site number ${ }^{3}$} & \multicolumn{3}{|c|}{$\begin{array}{c}\text { Gravity-station coordinate } \\
\text { [NAD83(2011) Epoch 2010.00, NAVD88/GEOID12B] }\end{array}$} \\
\hline & & & $\begin{array}{l}\text { Latitude, } \\
\text { north }\end{array}$ & $\begin{array}{l}\text { Longitude, } \\
\text { west }\end{array}$ & $\begin{array}{l}\text { Elevation, } \\
\text { in feet }\end{array}$ \\
\hline \multicolumn{6}{|c|}{ Paulden area-Continued } \\
\hline 13 & B-18-02 31BCB & USGS 345423112311901 & 34.904382 & 112.523015 & $4,400.21$ \\
\hline 14 & B-18-03 26BBC ${ }^{4}$ & USGS 345518112332701 & $34.91889^{2}$ & 112.55399 & 4,413 \\
\hline \multicolumn{6}{|c|}{ Area West of Big Chino Wash } \\
\hline 15 & B-18-04 25AAA2 & $345524112374401^{1}$ & 34.923413 & 112.629583 & $4,573.66$ \\
\hline 16 & B-18-04 11ACC & $345738112391501^{1}$ & 34.960636 & 112.654888 & $4,617.96$ \\
\hline 17 & B-18-04 01ACA2 & $345842112380201^{1}$ & 34.978383 & 112.634785 & $4,558.18$ \\
\hline 18 & B-19-04 29DAB & USGS 350016112421001 & $35.00422^{2}$ & 112.70354 & 4,646 \\
\hline 19 & B-19-05 13BBA & USGS 345338112311801 & 35.040264 & 112.749957 & $4,902.62$ \\
\hline 20 & B-20-05 35DAD & USGS 350423112451101 & 35.072975 & 112.753834 & $4,832.31$ \\
\hline 21 & B-20-05 15CCC & USGS 350647112471101 & 35.112913 & 112.787294 & $4,979.24$ \\
\hline 22 & JUNIPER & NA & 35.095805 & 112.866067 & $5,783.33$ \\
\hline \multicolumn{6}{|c|}{ Big Chino Water Ranch area } \\
\hline 23 & B-19-04 10CCB2 & AZ014 350232112404901 & 35.042192 & 112.680942 & $4,525.83$ \\
\hline 24 & B-19-04 09ACD & AZ014 350253112411201 & $35.04788^{2}$ & 112.68729 & 4,547 \\
\hline 25 & B-19-04 04CAC & USGS 350332112413701 & 35.058584 & 112.694439 & $4,536.94$ \\
\hline 26 & B-19-04 05ABA & USGS 350403112421801 & 35.067584 & 112.705678 & $4,569.24$ \\
\hline 27 & B-20-04 33CBD2 & AZ014 350427112414701 & 35.074071 & 112.697167 & $4,558.17$ \\
\hline 28 & B-20-04 32CAB & $350433112424101^{1}$ & 35.075711 & 112.711128 & $4,570.78$ \\
\hline 29 & B-20-04 32BBA & USGS 350500112424601 & 35.083248 & 112.713617 & $4,566.50$ \\
\hline 30 & B-20-04 19CBA & USGS 350616112435601 & 35.104530 & 112.732996 & $4,597.24$ \\
\hline 31 & B-20-04 18CDC & USGS 350648112434201 & 35.114137 & 112.729737 & $4,597.73$ \\
\hline 32 & B-20-05 13DAA & USGS 350709112441101 & 35.119344 & 112.737070 & $4,607.83$ \\
\hline
\end{tabular}

\footnotetext{
${ }^{1}$ Site is inventoried only in the Arizona Department of Water Resources Groundwater Site Inventory database (Arizona Department of Water Resources, 2018).

${ }^{2}$ Position determined using hand-held Global Positioning System in World Geodetic System 1984 (WGS84) datum.

${ }^{3}$ Agency code refers to code in USGS GWSI database.

${ }^{4}$ Well is located 1,620 feet northwest of gravity station.
} 
monitoring wells, each about 2,500 ft from the pumped well, had higher transmissivity and lower storativity representative of the "regional" aquifer, $242,000\left(\mathrm{ft}^{2} / \mathrm{d}\right)$ and 0.015 , respectively. The local and regional wells likely represent an uppermost unconfined aquifer and deeper confined to semiconfined aquifer, respectively. Semiconfined (or "leaky") aquifers are those that are saturated, have a potentiometric surface higher than the top of the aquifer, and receive recharge from adjacent semipermeable units.

The Bureau of Reclamation collected geophysical, drilling, and hydrologic data in the early 1990s (Ewing and others, 1994). As with the Water Resources Associates (1990) study, a playa deposit forming a thick and extensive unit was noted, but borehole and geophysical data suggested any resultant zone of low transmissivity did not extend entirely across the valley, nor all the way to Paleozoic sedimentary rock or impermeable bedrock beneath the basin. Analysis of groundwaterlevel data at wells located at T. 18 N., R. 3 W., 26ACC and T. 18 N ., R. 3 W., 31BCB (see Supplemental Information in the front of this report for explanation) indicated unconfined and confined conditions, respectively; confined conditions were indicated by the correlation between groundwater level and barometric pressure. No wells in the USGS or ADWR databases are present in either location, although there is a well B-18-02 31BCB. Regardless, the data indicate confined and unconfined conditions in the study area.

Connection between groundwater in Big Chino Valley and the Verde River headwaters was hypothesized by Wirt and Hjalmarson (2000) on the basis of a period of heavy pumping to fill several artificial ponds a few miles northwest of Paulden. This period of pumping had an apparent relation with a decrease in base flow of about 25 percent ( 5 cubic feet per second, $\mathrm{ft}^{3} / \mathrm{s}$ ) in the Verde River, which recovered rapidly when pumping ended (White, 1965; Wirt and Hjalmarson, 2000). Wirt and others (2005) used geochemical modeling to estimate that up to 86 percent of Verde River base flow was sourced from the basin-fill aquifer in Big Chino Valley. Based on a groundwater-modeling exercise, Ewing and others (1994) found that the upper and lower parts of Big Chino Valley are hydrologically connected and that the flows in the Verde River can be accounted for by the stream channel and precipitation recharge sources in Big Chino Valley. Other hydrologists have questioned a connection between Big Chino Valley groundwater and the upper Verde River Springs, hypothesizing that an impermeable layer exists between alluvial-basin groundwater and groundwater in a deeper, regional groundwater system that feeds the springs, and (or) that spring discharge is correlated with variation in precipitation and not basin-fill groundwater levels (see Errol L. Montgomery and Associates, Inc., 2007, and Arizona Office of Administrative Hearings, [2019]).

A hydrogeologic framework of the subbasin based on geophysical methods, including the distribution of volcanic units and depth to bedrock based on aeromagnetic and gravity datasets, was completed by Langenheim and others (2005). A water-budget conceptualization for the subbasin, building on several previous water budgets, was completed by Blasch and others (2006). The water budget considered the entire Big
Chino Subbasin, a larger area than was evaluated in the present report. Recharge estimated using an excess-precipitation method (based on the difference between monthly precipitation and evapotranspiration) suggested only a small high-elevation part of the subbasin (18 percent) contributed recharge (in addition to an unknown amount of recharge in stream channels) and that recharge was 1.3 percent of precipitation.

The most recent USGS groundwater-modeling project in the region, covering most of northern Arizona, concluded that more information about aquifer extents and aquifer-storage properties was needed to reduce modeling uncertainty and improve estimates of storage change in the Big Chino Subbasin (Pool and others, 2011). Estimates of storage change in the subbasin have typically been extrapolated from water-level changes assuming unconfined conditions in one or more index wells; such estimates require an assumed value of specific yield. In contrast, the repeat microgravity aquifer-storagechange measurements presented in this report are independent of specific yield.

\section{Setting}

The study area lies within the southern part of the Big Chino Subbasin (Arizona Department of Water Resources, 2010) in the transition zone between the Basin and Range and Colorado Plateau physiographic provinces (Wilson and Moore, 1959), which features extensive deformation caused by faulting and uplift resulting from periods of extension and compression. The southern part of the Big Chino Subbasin includes two connected alluvial-fill basins, one in the Big Chino Valley west and northwest of the community of Paulden beneath Big Chino Wash that is relatively deep and underlain primarily by Paleozoic sedimentary rocks, and a shallower basin in Williamson Valley west and southwest of Paulden beneath Williamson Valley Wash, underlain primarily by Precambrian igneous and metamorphic rocks and bounded by several small faults and Tertiary volcanic formations (DeWitt and others, 2008). The Big Chino Wash part of the subbasin is bounded to the northeast by the Big Chino Fault (fig. 2), a northwest-southeast trending normal fault with little to no vertical displacement at its southeast end and maximum displacement of about $3,500 \mathrm{ft}$ occurring to the northwest. Groundwater outside the study area in the northern part of the Big Chino Subbasin occurs primarily at depths greater than several hundred feet below land surface in Paleozoic sedimentary rocks. Groundwater development is limited primarily to small commercial providers in Ash Fork and Seligman (Arizona Corporation Commission, 2018). Groundwater data is sparse in this region but groundwater flow is generally to the north towards springs and seeps in the Grand Canyon (Arizona Department of Water Resources, 2010).

The Verde River, with headwaters just southeast of Paulden, is the primary perennial surface-water feature in the Big Chino Subbasin. Short reaches of Williamson Valley Wash north (downstream) of Williamson Valley Road are also perennial, and several small springs and seeps are found in the surrounding mountains. The Verde River begins about a mile 
Aquifer Storage Change and Storage Properties, 2010-2017, in the Big Chino Subbasin, Yavapai County, Arizona

below Sullivan Dam, where several springs (the upper Verde River springs) continuously discharge into the channel. Sullivan Dam is a sediment-filled impoundment that holds a small amount of water when there is storm runoff in Big Chino Wash.

Surface-water runoff in response to precipitation drains through Big Chino Wash in the Big Chino Valley, which is roughly 28 miles long and ranges in width from 2 miles in the northwest to approximately 6 miles at its terminal end to the southeast, near Paulden. Major tributaries to Big Chino Wash above the Verde River headwaters include Partridge Creek, Walnut Creek, and Williamson Valley Wash. The alluvial-fill part of the Big Chino Subbasin is smaller than the watershed. The total watershed area at the confluence of Big Chino Wash and Williamson Valley wash is about 1,790 square miles $\left(\mathrm{mi}^{2}\right)$. Of this, $554 \mathrm{mi}^{2}$ in the Partridge Creek watershed, 480 $\mathrm{mi}^{2}$ in the upper part of the subbasin (above the Big Chino Wash-Turkey Canyon confluence), and $82 \mathrm{mi}^{2}$ in the Walnut Creek watershed are largely outside the alluvial-fill subbasin - areas obtained from the USGS Streamstats application (U.S. Geological Survey, 2018). There is approximately 225 $\mathrm{mi}^{2}$ of Tertiary to Quaternary sedimentary rocks and alluvial fill mapped in the Big Chino Wash part of the subbasin and $150 \mathrm{mi}^{2}$ in the Williamson Valley Wash part of the subbasin (DeWitt and others, 2008). Major mountain ranges within the subbasin include Big Black Mesa to the northwest of Big Chino Valley and drained by Partridge Creek and the upper part of Big Chino Wash, the Juniper Mountains, the Santa Maria Mountains, drained by Pine Creek, Walnut Creek, and Williamson Valley Wash, and the Sullivan Buttes volcanic field, located between Williamson Valley Wash and the lower part of Big Chino Wash.

\section{Climate}

The climate in the region is semiarid to arid, with average annual temperatures and precipitation highly dependent on elevation. Severe winters and mild summers are common at higher altitudes, and mild winters and extreme heat are typical at lower altitudes. Average annual precipitation in the valleys is about 10 to 13 inches per year, whereas higher altitudes may receive 15 to 30 inches per year (PRISM Climate Group, 2018). Most precipitation occurs during the summer monsoon season, typically July through September. A second wet season in the winter, generally lasting from December through March, can include snow at higher altitudes. Additional precipitation from tropical disturbances may occur in the fall, and although rare, may be an important source of heavy precipitation, streamflow, and recharge.

\section{Hydrogeology}

Formation of the Big Chino Valley was initiated about 8-10 million years ago by normal faulting to the northeast and southwest of the valley, forming a graben that filled over time with eroded sediments from the surrounding mountains (Wirt and others, 2005). Fault movement since the late Tertiary has been primarily along the Big Chino Fault, which was active until at least late Quaternary time (about 15 thousand years ago; Euge and others, 1992). In some places, movement of the Big Chino Fault creates a series of terraces between the fault and the modern-day stream channel of Big Chino Wash. (Soule, 1978). Basin fill is composed of up to several thousand feet of unconsolidated, Tertiary to Quaternary sediments interbedded with basalt flows originating from the north, west, and southeast of the valley (Wirt and others, 2005). A thick fine-grained clay unit in the center of the basin (Ostenaa and others, 1993) delineates what once was a playa. This clay unit and other fine-grained units leads to confined or semiconfined aquifer conditions in some places. The crest of Big Black Mesa on the northeast side of the valley is thought to form a groundwater divide between the aquifer systems in the valley and those to the north (Pool and others, 2011), although northward-flowing groundwater from Big Black Mesa is included in the Big Chino Subbasin as mapped by ADWR (Arizona Department of Water Resources, 2000). Crystalline rock at the base of the mesa likely is an effective barrier to northerly groundwater flow out of the alluvial basin (Pool and others, 2011).

The basin fill and underlying Paleozoic unit(s) constitute an aquifer system that underlies most of the Big Chino Valley. The upper aquifer, in the Chino Valley Unit (Arizona Department of Water Resources, 2000) and divided into upper and lower parts (each with fine- and coarse-grained facies) by Pool and others (2011), is composed of unconsolidated sedimentary materials, interbedded with volcanic rocks. This aquifer system can be confined to semiconfined or unconfined and tends to become increasingly fine grained towards the valley center. Buried basalt flows occur throughout the basin fill and are associated with high transmissivity in the Paulden area, but not in the Big Chino Water Ranch (BCWR) area, where volcanic units (basalt, breccia, and agglomerate) and sediments below the volcanic units yield less water to wells than the sediment overlying the volcanic units. Based on driller's logs, the buried playa in the center of Big Chino Valley is at least 1,800 ft thick (Wirt and others, 2005). The spatial extent of the buried playa is not well-constrained by drilling or geophysics (Macy and Heilman, 2018). Basin-fill thickness elsewhere in the subbasin ranges from a few hundred feet on average to a few thousand feet thick in some places (Ostenaa and others, 1993; Langenheim and others, 2005; Wirt and others, 2005).

Connectivity between the Paleozoic and basin-fill aquifers is not well constrained for much of their areal extent, but groundwater likely flows from carbonate units to the basinfill aquifer where they are present at the edge of the basin (Pool and others, 2011). The basin-fill aquifer is assumed to discharge to the lower carbonate aquifer in the Paulden area, which then discharges at the upper Verde River springs (Blasch and others, 2006). Quaternary stream alluvium, of limited areal extent and depth, may provide water for shallow wells in the area but is typically unsaturated. 


\section{Aquifer Properties}

Aquifer tests to estimate aquifer properties have been carried out in the study area. Specific capacity (the ratio of pumping rate to drawdown in a well) tests are most common. Transmissivity can be estimated from specific capacity (Theis, 1963), and specific capacity is related to the aquifer storage coefficient, but the relation is not sufficiently sensitive to make accurate estimates (Meyer, 1963). Two 14-day pump tests (7 days of pumping and 7 days of recovery) were carried out at wells B-19-04 03BCD and B-17-02 04CDA (Water Resources Associates, 1990). At well B-19-04 03BCD, located near the Big Chino Water Ranch (BCWR), 1.0 mile east-northeast from well B-19-04 04CAC (station 25; fig. 3), and screened from 107 to $698 \mathrm{ft}$ below land surface, results were interpreted as indicating a semi-unconfined aquifer with a storage coefficient ranging from 0.33 to 0.41 . However, these values were judged to be too high (Water Resources Associates, 1990), and a range from 0.03 to 0.3 was deemed appropriate for the aquifer lithology. At well B-17-02 04CDA (near station 7; fig. 3), located in the Paulden area near the confluence of Big Chino Wash and Williamson Valley Wash, aquifer-test results indicated a complex aquifer with a significant vertical flow component, extremely high transmissivity $\left(60,200\right.$ to $\left.334,000 \mathrm{ft}^{2} / \mathrm{d}\right)$, and nearby permeable and impermeable hydrologic boundaries. Data also indicated incomplete recovery of the water level in the well after the end of pumping caused by dewatering of the basalt aquifer (occupying a $56 \mathrm{ft}$ interval in the center of the $400 \mathrm{ft}$ uncased, pumped borehole) and slow recharge from the surrounding alluvium. The average specific yield was 0.29 , interpreted to represent a fractured basalt aquifer.

Additional aquifer test data indicates high transmissivity in places, in particular the upper alluvium in the BCWR area, and within basalt units in the Paulden area. From pumping tests and other sources, Southwest Groundwater Consultants (2007) estimated transmissivities between 870 and 46,100 $\mathrm{ft}^{2} / \mathrm{d}$. Specific yield ranged between 0.0004 and 0.44 . Using a groundwater model, calibration results indicated a specific yield value between 0.05 and 0.2 in the upper two model layers that received recharge. Specific storage for all seven model layers ranged between $5.8 \times 10^{-4}$ to $1.0 \times 10^{-7} \mathrm{ft}^{-1}$. Transmissivity estimates for the basin fill aquifer compiled by Clear Creek Associates (2008) ranged from 15,000 to $18,000 \mathrm{ft}^{2} / \mathrm{d}$, with hydraulic conductivities ranging from 1 to 65 feet per day (ft/d). Specific yield values from a regional groundwater flow model (Pool and others, 2011) for the interbedded basin fill of the uppermost model layer ranged from 0.05 to 0.15 . Fine-grained intervals of basin fill in layer 1 in the Big Chino Subbasin were assigned a specific yield value of 0.01 .

\section{Groundwater Conditions}

Groundwater flow in the basin-fill aquifer of Big Chino Valley is generally to the southeast, but is not perfectly aligned with surface flows, likely due to faulting and heterogeneity of the subsurface (Flora and others, 2009). Groundwater in the Williamson Valley area flows to the north and northeast into the Big Chino Valley area. The Little Chino Subbasin, east of Williamson Valley Wash, drains into the Big Chino Subbasin near the headwaters of the Verde River. A groundwater divide formed by igneous rocks likely exists between the Williamson Valley Wash part of the subbasin and the Little Chino Subba$\sin$ (Navarro, 2002).

There are few groundwater-level data for the region prior to agricultural development. Variation in groundwater-level trends with time are locally related to changes in agricultural water use, with little to no average change noted between 1975 and 1992. Positive storage changes estimated from increases in groundwater levels occurring during this time are attributable to changes in irrigation strategies (Schwab, 1995). Groundwater levels in wells monitored since the 1950s in the southern part of the subbasin increased between the 1950s and 1990s but declined from 1993 to 2003 at rates between -0.5 to $-0.75 \mathrm{ft} / \mathrm{yr}$ (Arizona Department of Water Resources, 2018). Increasing and decreasing trends in groundwater elevations in this part of the subbasin mirror trends in base flow observed in the Verde River (Blasch and others, 2006).

At present, pumpage in the Big Chino Subbasin is for domestic use, agriculture, and a small amount of commercial use. Two commercial water providers in the Paulden area deliver water to residential customers; about 160 acre- $\mathrm{ft}$ of water was delivered annually to about 650 customers between 2012 and 2016 (Arizona Corporation Commission, 2018). A relatively small amount of irrigated agriculture occurs in the subbasin, including about 700 acres near the BCWR area, 200 acres in the Paulden area, 60 acres in the Walnut Creek area, and 700 acres in the Williamson Valley area. Smaller parcels of irrigated land are distributed throughout the subbasin.

Historically, groundwater withdrawals for irrigation in the Big Chino Valley were greater than at present, reaching a maximum of about 15,000 acre-ft/yr for the period 1960-1972 (Blasch and others, 2006). Withdrawals steadily decreased from 1972 until the mid-1990s, reaching a minimum of about 7,500 acre-ft. Withdrawals then increased slightly to around 10,000 acre-ft/yr until the mid-2000s, when the City of Prescott purchased the JWK ranch, which was renamed the Big Chino Water Ranch, and retired 1,256 acres of irrigated land, reducing groundwater withdrawals by about 2,900 acre-ft/yr (based on average withdrawals of 2.29 acre-ft of water per acre from 2013-2016 water use data). Outside of the BCWR, a small amount of other groundwater-irrigated land has been repurposed for residential development, primarily near Paulden. Also near Paulden, approximately 220 acres of newly irrigated land was established in the mid to late 2000s. Of this, about 180 acres are located west of well B-18-02 31BCB (station 13; fig. 3), and 40 acres are southwest of well B-17-02 04DBC1 (station 7; fig. 3).

\section{Surface-Water Conditions}

Base flow in the Verde River near Paulden gage (USGS station 09503700; fig. 3) typically ranges between 22 and 26 $\mathrm{ft}^{3} / \mathrm{s}$ (Owen-Joyce and Bell, 1983; Pope and others, 1998; also see fig. 6 later in this report). The drainage area is $2,507 \mathrm{mi}^{2}$ 
and includes contributing area in the Little Chino Subbasin outside of the Big Chino Subbasin. Maximum discharge during the 1963-2017 period of record was 23,200 ft³ in 1993. The lowest daily mean discharge, $15.0 \mathrm{ft}^{3} / \mathrm{s}$, was recorded in May 1964, soon after the gage was installed. During the study period the lowest daily mean discharge was $16.6 \mathrm{ft}^{3} / \mathrm{s}$ in 2015 , occurring after several years of drought in the region. The initial 0 to 0.2 miles of the Verde River have base flow of about $1 \mathrm{ft}^{3} / \mathrm{s}$, on average, which increases to about $17 \mathrm{ft}^{3} / \mathrm{s}$ by mile 2.2, due to the discharge from the upper Verde River springs (Blasch and others, 2006).

The Williamson Valley Wash near Paulden gage (USGS station 09502800; fig. 3) records discharge during the summer monsoon season and during the winter. Periods of zero flow are common before and after the summer monsoon season, when evapotranspiration demand is high. Except during large storm runoff events, most or all of the base flow at the Williamson Valley Wash re-infiltrates before reaching the Verde River near Paulden gage. Therefore, this area of groundwater discharge does not represent a discharge zone separate from that of the upper Verde River springs. The drainage area is $255 \mathrm{mi}^{2}$, entirely within the Big Chino Subbasin. Maximum discharge during the 1965-2017 period of record was 14,800 $\mathrm{ft}^{3} / \mathrm{s}$ (the gage was not operated from 1986 to 2000). All surface-water drainages in the subbasin above the Verde River are ephemeral, except for short reaches of intermittent flow in Williamson Valley Wash and possibly tributary drainages. The only surface-water impoundments other than Sullivan Dam are small stock tanks of 1 acre or less.

\section{Methods}

Hydrologic data analyzed in this study include measurements of precipitation, streamflow, groundwater levels, and aquifer-storage change. Groundwater withdrawals for irrigation were also estimated. Data collected by USGS were augmented with additional data obtained from ADWR, the National Oceanic and Atmospheric Administration (NOAA), Yavapai County Flood Control District, and Salt River Project.

\section{Precipitation and Streamflow Data}

Precipitation data were evaluated for the magnitude of annual variability and in relation to groundwater level and storage changes. Data were obtained from the National Oceanic and Atmospheric Administration (2018) and from the Yavapai County Flood Control District (2018). Four stations were identified from the Global Historical Climate Network, near Ash Fork, Walnut Creek, Chino Valley, and Paulden (fig. 3). The Yavapai County Flood Control network installed a weather station (with precipitation data) on the Big Chino Water Ranch in 2014. Not all stations had continuous data during the study period.

Discharge was measured at two USGS streamgaging stations in the study area, Williamson Valley Wash near Paulden,
Arizona (09502800) and Verde River near Paulden, Arizona (09503700). The drainage area for the Williamson Valley Wash streamgage is $255 \mathrm{mi}^{2}$, and the period of record is 1965 present. The drainage area for the Verde River streamgage is 2,507 $\mathrm{mi}^{2}$, and the period of record is 1963-present. A third streamgage in the study area, Big Chino Wash at Paulden, Ariz. (09502830) was established in late 2017, and data were not available for this report. Additional estimates of streamflow were provided by Salt River Project (written commun., 2017) using a combination of continuous-recording pressure transducers and photography.

Mean monthly base flow was calculated using the automated procedure HYSEP (Sloto and Crouse, 1996), following the same methodology as Blasch and others (2006). The fixedinterval method was used, which has the effect of connecting lines through the low points in the hydrograph, thereby eliminating stormflow peaks from the discharge record.

\section{Groundwater Withdrawals}

All agriculture in the study area relies on groundwater for irrigation and livestock. As part of ongoing monitoring in Arizona, USGS estimates total irrigation withdrawal for subbasins throughout the State (Tadayon, 2005). For this study, irrigation was estimated by crop and crop acreage, consumptive waterrequirement rates for crops, and irrigation system efficiency. Irrigated acreage was delineated using aerial photography and then field verified. Consumptive water-requirement rates for crops were determined using a modified Blaney-Criddle method (Dickens and others, 2011). Irrigation efficiency was then estimated, based on an estimate of conveyance losses during transport and the type of irrigation system used to apply water. Considering all these factors, water-use estimates were determined on a field-by-field basis where metered data were otherwise unavailable.

\section{Groundwater-Level Monitoring}

Groundwater levels are monitored in the Big Chino Subbasin by USGS and ADWR. USGS groundwater-level measurements are primarily at wells collocated with aquiferstorage (repeat microgravity) monitoring. At five wells, continuous groundwater levels were recorded at 4- to 6-hour intervals using vented pressure transducers. Discrete groundwater-level measurements (that is, measurements made during periodic site visits) were made at an additional eight wells. ADWR collects continuous groundwater-level data at 6-hour intervals at four wells. In addition, ADWR makes annual or semiannual measurements at about 88 index wells in and around the Big Chino Subbasin.

Groundwater-records were evaluated for linearity and trends using linear regression and a Mann-Kendall trend test, respectively. Linearity was identified as a useful metric, as many of the wells show uniform, monotonic trends over many years, without significant departures indicative of recharge events. Only data from 2010-2017 were considered, and only 
wells with five or more measurements during that period were included. Using linear regression, wells with a Pearson correlation coefficient greater than 0.75 were identified as having a linear record. Linearity in this context implies only that measurements fall approximately along a straight line, and does not imply an upward or downward trend. Using the Mann-Kendall trend test (Helsel and Hirsch, 2002), wells were identified for which the null hypothesis (that no trend exists) was rejected at the 95-percent confidence level. Mann-Kendall is a nonparametric test that evaluates whether values tend to increase or decrease monotonically over time.

\section{Aquifer-Storage Monitoring}

Changes in aquifer storage were monitored using the repeat microgravity method. The Earth's gravitational field, as described by Newton's law of gravitation, varies temporally because of changes in subsurface and atmospheric mass. In groundwater systems, changes in the amount of water stored in aquifers or in the unsaturated zone between an aquifer and the land surface cause changes in the magnitude of Earth's gravity. Measurements of changes in gravity ("repeat microgravity") have proven useful for many applications, including mapping aquifer storage change (Pool and Anderson, 2008), determining specific yield (Pool and Eychaner, 1995), resolving total water-storage-change into various partitions (Creutzfeldt and others, 2010), and monitoring the depth of the wetting front at an artificial recharge facility (Kennedy and others, 2014). For this study, repeat microgravity is used to investigate changes in aquifer storage and to identify the aquifer specific yield (that is, the volume of water released or stored in the aquifer per unit area per unit head change in an unconfined aquifer).

Gravity data are reported in units of microgal $(\mu \mathrm{Gal})$. The gal is a unit of acceleration equal to 1 centimeter per second squared $\left(\mathrm{cm} / \mathrm{s}^{2}\right)$ or about $1 / 1,000$ th of Earth's gravitational field. One $\mu \mathrm{Gal}$ is about $1 \times 10^{-9}$ or 1 part per billion of Earth's gravitational field. If the water table moves uniformly up and down (that is, changes in storage are one dimensional), the horizontal infinite-slab model is appropriate to directly convert gravitational units (that is, acceleration in $\mu \mathrm{Gal}$ ) to a thickness of water (Pool, 2008). Using this approximation, also known as the Bouguer slab model, $12.77 \mu \mathrm{Gal}$ of gravity change is equivalent to $1 \mathrm{ft}$ of water-storage change in the aquifer, regardless of aquifer porosity or depth to groundwater (Torge, 1989). The gravity method thus has the advantage of not being sensitive to the aquifer-storage coefficient, because it directly measures the change in the mass of water stored in the aquifer. In contrast, groundwater levels measured in wells require a storage-coefficient estimate to convert the measured change in water level to the change in aquifer storage; an unconfined aquifer with high specific yield may store a large amount of water with a relatively small change in water level, whereas a confined aquifer with a low storativity may show a much larger change in water level in a well for the same change in storage. The aquifer-storage coefficient is the volume of water released from storage for a given change in hydraulic head; in an unconfined aquifer it is known as specific yield and in a confined aquifer as storativity. The aquifer-storage coefficient is typically poorly defined because it is difficult or impossible to measure or estimate over a representative portion of the aquifer. As a result, storage changes inferred only from groundwater-level changes in a well have relatively high uncertainty.

Absolute-gravity data were primarily collected using a Micro-g LaCoste, Inc., A-10 free-fall absolute gravity meter. This meter measures the position of a falling mass using a length scale determined by a laser interferometer and a time scale determined by a rubidium oscillator. A spring mechanism isolates the interferometer from long-period seismic noise. Each measurement consists of about 1,000 drops during a 30-minute period. Nominal accuracy is $\pm 10 \mu \mathrm{Gal}$ for the A-10, although in practice the estimated accuracy is \pm 5 to $8 \mu \mathrm{Gal}$ (Schmerge and Francis, 2006). Absolute-gravity data were collected at one station, Paulden AA, by the National Geodetic Survey using an FG-5 absolute gravity meter. The FG- 5 has the same operating principles as the A-10, but with a longer falling distance and slower drop time. Measurements are more accurate, about \pm 2 $\mu \mathrm{Gal}$, but require 24 hours or longer per measurement. Additional measurements using the A-10 absolute-gravity meter were made at Paulden AA and an adjacent outdoor station in 2016-2017.

Earth-tide corrections for absolute-gravity measurements were determined using the ETGTAB model with the default wave groups in the Micro-g Lacoste software. Ocean-loading corrections were determined using the FES2004 model, produced by Legos and CLS Space Oceanography Division and distributed by Aviso, with support from Cnes (see http:// www.aviso.oceanobs.com/). Polar-motion corrections were determined by Micro-g Lacoste software using coordinates provided by the U.S. Naval Observatory. The barometric pressure correction was calculated using measured barometric pressure and an admittance factor of 0.3 microgal per millibar. Uncertainty in each of these corrections is less than $0.1 \mu \mathrm{Gal}$ and is reflected in the measurement error bars.

Where possible, gravity stations were located using a differential GPS receiver mounted on top of the A-10 absolutegravity meter. Station occupations were between 30 and 60 minutes. Station positions in the North American Datum of 1983 (NAD83) 2011 (epoch 2010.00) datum were determined using the Online Positioning User Interface (National Geodetic Survey, 2018). Other station positions were estimated from orthorectified satellite imagery. Gravity data and accompanying metadata are published in an accompanying data release (Kennedy and others, 2019).

\section{Soil-Moisture Correction}

Gravity data provide an integrative measurement of all water-storage changes in the subsurface, from the land surface to the water table. Mass changes below the water table were considered negligible, as changes that occur through compression/decompression of an aquifer are generally too small to cause a measurable change in gravity. Large changes in 
water-storage take place primarily near the land surface and at the water table. Near the land surface, water-storage changes are caused by precipitation and evapotranspiration. Following a rainfall event, the pulse of high soil moisture near the land surface is attenuated as it moves downward through the soil profile, and water content below a particular depth (the "damping depth") is relatively uniform over time (Corona and others, 2017). In a semiarid environment like the Big Chino Subbasin, large fluctuations in water content are confined to the uppermost few meters of the unsaturated zone (Scott and others, 2000). Therefore, only the uppermost part of the soil profile needs to be considered with respect to soil-moisture changes.

When using repeat microgravity to measure changes in aquifer storage, near-surface soil moisture represents a source of "noise" that should be removed to more precisely measure the aquifer-storage change signal. During this project, soil moisture was measured using time-domain reflectometry and by weighing and oven drying soil samples. These samples, although useful to identify relatively wet or dry conditions, do not provide the continuous-in-time coverage required to correct gravity data; that is, a soil-moisture estimate is required at every gravity station at every time a measurement was made.

Remote-sensing (satellite) soil-moisture estimates were used to provide a continuous soil-moisture time series. Although various remote sensing soil-moisture products exist, all sample only the top few centimeters of soil. An infiltration model is required to generate a soil-moisture time series for the root zone (in this case, assumed to be the uppermost $3.3 \mathrm{ft}$ of the subsurface). One such root-zone soil-moisture product is the National Aeronautics and Space Administration, National Snow and Ice Data Center, Soil Moisture Active Passive (SMAP) Surface and Root Zone Soil Moisture Analysis Update (Reichle and others, 2017). This product provides soil moisture to $3.3-\mathrm{ft}$ depth at 5.6 by 5.6 mile ( 9 by 9 kilometer, $\mathrm{km}$ ) spatial resolution at 3-hour intervals from April 2015 through 2017. To extend the soil-moisture record back further in time, a second root-zone soil-moisture dataset was obtained from Copernicus Global Land Service (Copernicus Service information, 2017). This product, derived from the Advanced Scatterometer (ASCAT) instrument on the European Space Agency Metop-A and Metop-B satellites, provides soil moisture (denoted soil-water index) at 0.4, 2.0, 3.9, 5.9, 7.9, 15.7, 23.6, and 39.4 inches. $(1,5,10,15,20,40,60$, and 100 centimeters, $\mathrm{cm}$ ) depths at daily intervals (Albergel and others, 2008). As noted in the data documentation, these depths indicate relative positions in the soil profile, but their representativeness of specific depths at individual stations must be determined by the user. To do so, various thicknessweighted averages of ASCAT soil moisture were compared with SMAP (which provides a single, average root-zone soil moisture) for the overlapping 2015 to 2017 period. The single ASCAT soil-moisture product for 23.6 inches $(60 \mathrm{~cm})$ depth was most similar to SMAP. ASCAT data were not used for the entire time series, because it has poorer spatial resolution than SMAP and indicated a large spike in soil moisture in 2017 that was poorly supported by rainfall data.
To carry out the soil-moisture correction from the continuous soil-moisture time series, the departure from the mean root-zone soil moisture was calculated at each station at each measurement time. If a gravity station were located on a flat plain, with no surrounding topography, the "horizontal infinite slab" approximation ( $1 \mathrm{ft}$ of water $=12.77 \mu \mathrm{Gal})$ could be used to convert soil moisture to a gravity signal (after correcting for soil-moisture variation, this same approximation is used to convert gravity changes to aquifer-storage changes). However, in an area such as the Big Chino Subbasin, some root-zone soil-moisture variation occurs above the elevation of the gravity station (for example, soil moisture stored in upland areas, above the valley floor). This increase in soil moisture causes a decrease in gravity, opposite the typical relation (an increase in the amount of water above a station "pulls up" on the gravity meter). To account for the departure from a horizontal infinite slab relation caused by topography, the gravitational attraction of a 1-meter (m) thick layer of water to a distance of $10 \mathrm{~km}$ was calculated for each station based on the surrounding terrain. This correction factor (known as an admittance factor in gravity literature) is then multiplied by the departure from the mean root-zone soil moisture at each station for each measurement time.

The composite (SMAP and ASCAT) root-zone soil moisture varies from 0.017 to 0.195 cubic meter per cubic meter $\left(\mathrm{m}^{3} / \mathrm{m}^{3}\right)$ (fig. 4), with an average soil moisture of $0.077 \mathrm{~m}^{3} / \mathrm{m}^{3}$. The gravitational soil-moisture admittance factor varies from 28.4 to $46.3 \mu \mathrm{Gal}$ per meter of water across all 31 gravity stations (the admittance factor can be greater than the horizontal infinite slab admittance factor, $12.77 \mu \mathrm{Gal}$ per foot of water, if the surrounding terrain is below the elevation of the gravity station). The soil-moisture gravity correction varied from -2.7 to $4.2 \mu \mathrm{Gal}$; the mean correction was $-0.5 \mu \mathrm{Gal}$. In general, these soil-moisture induced changes are small relative to the magnitude of gravity changes. Uncertainty in the soil-moisture correction is estimated to be 20 percent of the correction, or 0.27 to $0.42 \mu \mathrm{Gal}$.

\section{Interpreting the Gravity/Groundwater-Level Relation}

Groundwater-level and repeat-microgravity measurements provide complimentary information about changes in aquifer storage. Groundwater-level variations provide the sense of storage change (increase or decrease) in the monitored aquifer but do not provide a quantitative measure of storage change. A positive linear relation between gravity changes and groundwater-level changes (as the groundwater level rises, gravity increases) generally indicates that groundwater levels represent unconfined conditions. As the water table rises, water is stored in previously air-filled pore space at the water table (or conversely, pores are drained as the water table falls). If the rise or fall of the water table is sufficiently large (more than about 2 to $3 \mathrm{ft}$ of elevation change), the change in mass caused by filling or draining pore space will cause a measurable change in gravity. If an unconfined aquifer is indicated by 
the groundwater-level and gravity relation, multiple unconfined aquifers cannot be ruled out without additional subsurface data.

In contrast to unconfined aquifers, where storage changes occur through draining and filling pore spaces within the interval of water-table change, in confined aquifers storage changes are distributed throughout the aquifer and are typically orders of magnitude smaller. Under confined conditions, water is stored by compression of both water and the aquifer skeleton and the aquifer remains fully saturated (these mechanisms also occur in an unconfined aquifer but are usually insignificant relative to the volume of water stored at the water table). The resultant mass change is much smaller than that caused by filling or draining pore space. Small changes in aquifer storage accompanied by relatively large changes in groundwater elevation indicate both that groundwater levels represent confined-storage changes and that unconfined-storage changes are minor. Small changes in aquifer storage accompanied by small changes in groundwater elevation are generally inconclusive.

In addition to storage/groundwater-level relations that indicate unconfined- or confined-storage changes, the two may be uncorrelated. This usually indicates a multiple-aquifer system and (or) unaccounted changes in unsaturated-zone water content. The lack of correlation of significant gravity change with groundwater-level variations indicates the well monitors only one of two or more intervals with significant storage change. Unaccounted unsaturated-zone changes will introduce noise to the gravity signal, potentially obscuring the storage/ groundwater-level relation.

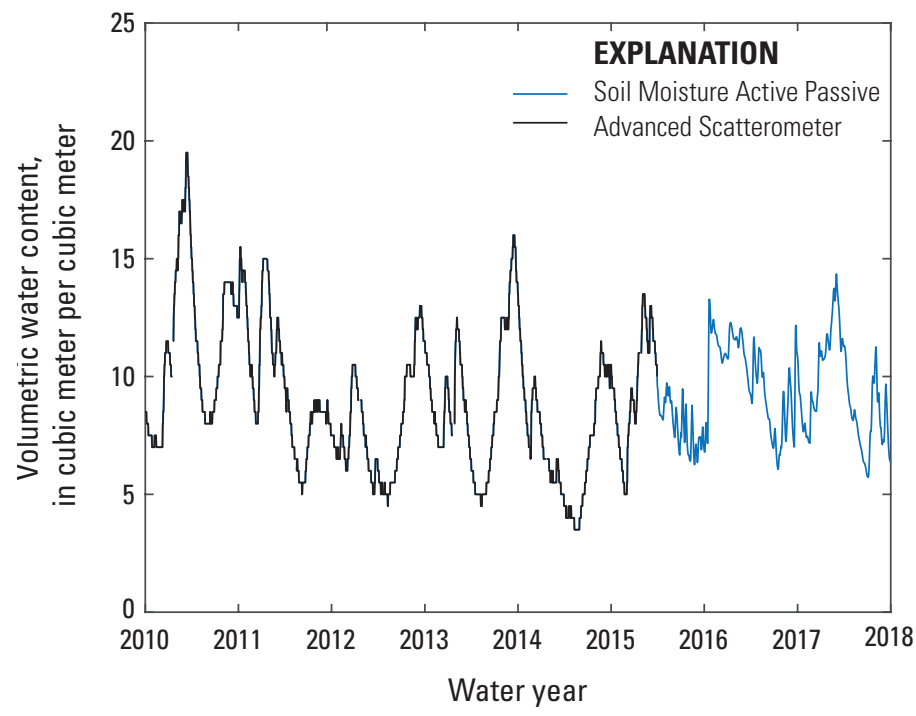

Figure 4. Graph of water-year time series showing root-zone soil-moisture satellite data used to correct gravity measurements from the Big Chino Subbasin in north-central Arizona for water years 2010 to 2017. Year is start (October 1 of previous year) of indicated water year (for example, October 1, 2013, for water year 2014). Satellite data are from (1) the National Aeronautics and Space Administration, National Snow and Ice Data Center, Soil Moisture Active Passive Surface and Root Zone Soil Moisture Analysis Update and (2) the Advanced Scatterometer instrument on the European Space Agency Metop-A and Metop-B satellites.
An important consideration in evaluating the aquifer-storage/groundwater-level relation is the location of the screened interval of the monitoring well (the part of the well that is open to the aquifer), which determines the aquifer region to which changes in groundwater level are sensitive - that is, the groundwater level is the average head over the screened interval. Many of the monitoring wells used in the study are screened over long intervals in the basin-fill alluvium, above the bedrock unit (carbonate or igneous) that forms the bottom of the sedimentary-fill aquifer, at depths between 200 to $500 \mathrm{ft}$. In an ideal unconfined aquifer, head changes at this depth would be identical to those recorded if the screened interval were located near the surface at the water table. In contrast, in a confined aquifer, head changes at depth are decoupled from head changes in the near-surface aquifer.

\section{Specific-Yield Estimation}

The linear relation between storage change and groundwater-level change in an unconfined aquifer provides a method to estimate specific yield for the interval of groundwater-level change that undergoes draining and (or) filling. Specific yield is the volume of water released (or stored) per unit area of aquifer per unit change in head. Specific yield is a dimensionless ratio, or equivalently, expressed in units of cubic meter per cubic meter. In an unconfined aquifer, specific yield is less than porosity on account of bound (immobile) water.

To estimate specific yield at a monitoring well where both gravity and groundwater levels are measured, measurement pairs of gravity change (converted to one-dimensional storage change) and groundwater-level change (both measurements made at the same time) are plotted on linear $y$ and $x$ axes, respectively. Measured changes are relative to the initial measurement at the station, and at least 2 measurements separated by 2 to $3 \mathrm{ft}$ of groundwater-level change are required. The specific yield is equal to the slope of a linear trend-line fit to the data. For example, if an aquifer with a specific yield of 0.5 undergoes a 1-m change in storage and a 2-m head change, the slope of the trend line will equal 0.5. Although two measurements are required at minimum, additional measurements relative to the initial measurement, preferably over a range of groundwater levels, can be plotted to improve the estimate of the trend-line slope.

As an alternative to plotting the correlation between storage change and groundwater-level change, the trend in each can be evaluated independently and compared. For example, if the trend in groundwater storage is $-1 \mathrm{ft}$ per year, and the trend in groundwater level is $-4 \mathrm{ft}$ per year, the specific yield can be estimated as 0.25 . This trend comparison method is useful when there is a long time series, sufficient to establish the presence of a trend, but measurement noise and (or) unaccounted-for processes (such as soil moisture) mask the presence of a linear storage/groundwater-level correlation. For this investigation, the plotting method was used where possible (that is, if the linear correlation was sufficient). At two stations, the plotting method was considered unacceptable and the trend-correlation method was used instead. 


\section{Results}

Monitoring results are presented by data type. The hydrologic context for groundwater-storage changes are presented below in Precipitation and Streamflow Trends, followed by estimated groundwater withdrawals. Finally, changes and trends in groundwater levels and aquifer storage are discussed by subarea (Williamson Valley Wash, Paulden, the area west of Big Chino Wash, and the Big Chino Water Ranch area).

\section{Precipitation and Streamflow Trends}

Annual rainfall in the study area varied between 4.3 and 17.1 inches at monitored locations from 2010 to 2017 (fig. 5). The average annual rainfall during this period was 13.0 3.1 inches. Rainfall in most years exhibits a bimodal pattern typical for the southwestern part of the United States, with two distinct periods of rainfall, during winter (December to March) and summer (July to October). During the previous decade (2000-2010), stations Chino Valley and Walnut Creek (the only stations with continuous records during this period) had rainfall as low as 5.5 and 6.1 inches in 2002 and as high as 18.8 and 26.0 inches in 2005. Based on rainfall, streamflow, and groundwater-level records, the last discrete recharge event that contributed recharge to the basin-fill aquifers in the study area occurred in winter 2004-2005, when precipitation caused long period of sustained flow and widespread inundation of low-lying areas near Paulden and in the BWCR area.

Base flow, calculated using an automated technique in HYSEP software (Sloto and Crouse, 1996), was consistently below the long-term average from 2010 to 2017 at the Verde
River near Paulden (09503700) and the Williamson Valley Wash near Paulden streamgages (09502800). Plots of the cumulative departure from the mean (fig. 6) show trends in precipitation and base flow; the cumulative departure is calculated by summing successive monthly departures from the average base flow during the period of record. Periods of lower-than-average base flow are shown by downward-sloping lines, and vice-versa for greater-than-average base flow. By definition, the cumulative departure curve starts and ends at zero.

Mean annual base flow at Verde River near Paulden has decreased from $25.1 \mathrm{ft}^{3} / \mathrm{s}$ during the 1964-2003 period (Blasch and others, 2006) to $24.2 \mathrm{ft}^{3} / \mathrm{s}$ during the 1964-2017 period (fig. 6). Two cumulative departure curves are shown in figure 5; one extends the Blasch and others (2006) analysis, using the same mean base flow $\left(25.1 \mathrm{ft}^{3} / \mathrm{s}\right)$, whereas the other shows the same data but using the revised 1964-2017 mean base flow $\left(24.2 \mathrm{ft}^{3} / \mathrm{s}\right)$. Both show the same trend: base flow was average to slightly below average from 1963 to 1979 , then entered a long stretch of above-average discharge from 1979 to 2000, corresponding to a period of above-average precipitation (fig. 6). Then, from 2000 to present, base flow has been average or lower than average nearly every month except during recharge events in 2000 and 2004-2005. Following the recharge event in 2004-2005, only 3 months have had greater than average base flow during the 2010-2017 period, and base flow has become increasingly lower than average, as shown by the increasingly negative slope of the cumulative departure curves (fig. 6). In addition to decreasing groundwater to discharge, reduced base flows may be caused by an increase in evapotranspiration caused by more abundant and mature vegetation; an increase in vegetation has been observed anecdotally during site visits to the Verde River near Paulden gage but has not been quantified.

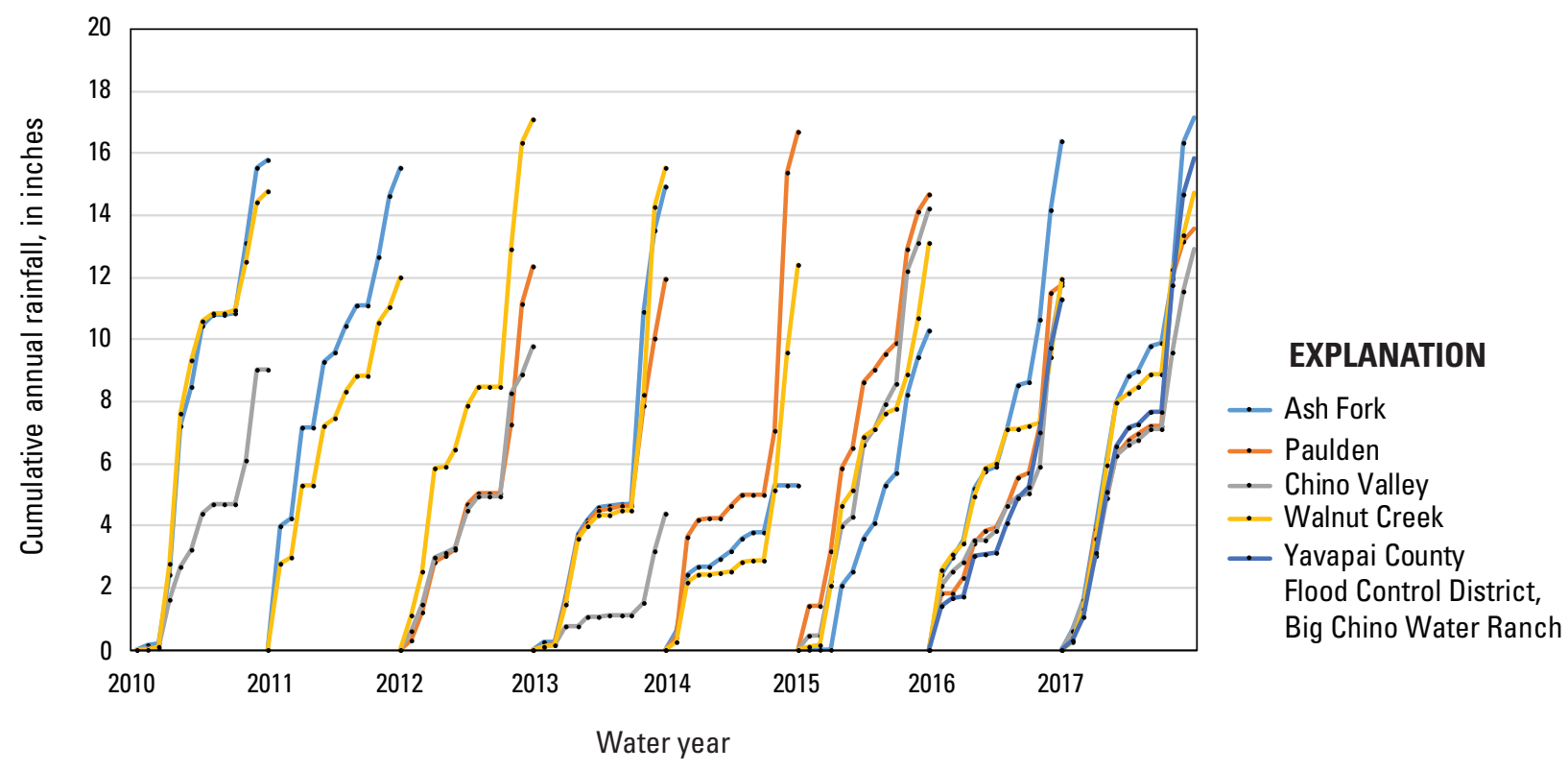

Figure 5. Graph showing precipitation at five stations in the Big Chino Subbasin in north-central Arizona for water years 2010 to 2017. Year is start (October 1 of previous year) of indicated water year (for example, October 1, 2009, for water year 2010). See figure 3 for station locations. 
The streamflow record at Williamson Valley Wash near Paulden, Arizona, shows a similar pattern of base flow as the Verde River near Paulden gage. Although the 1985-2001 period is missing, periods of higher than average base flow beginning in the late 1970s and lower than average base flow from 2002 onward are clear. The 2004-2005 recharge event is apparent as a sustained period of above-average base flow, as is a nearly equally large event in 2010 not observed at the Verde River near Paulden gage. However, following the 2010 event, base flow is well below average and periods of zero flow (indicated by $-1.72 \mathrm{ft}^{3} / \mathrm{s}$ departures from the mean in fig. 6) become increasingly common.
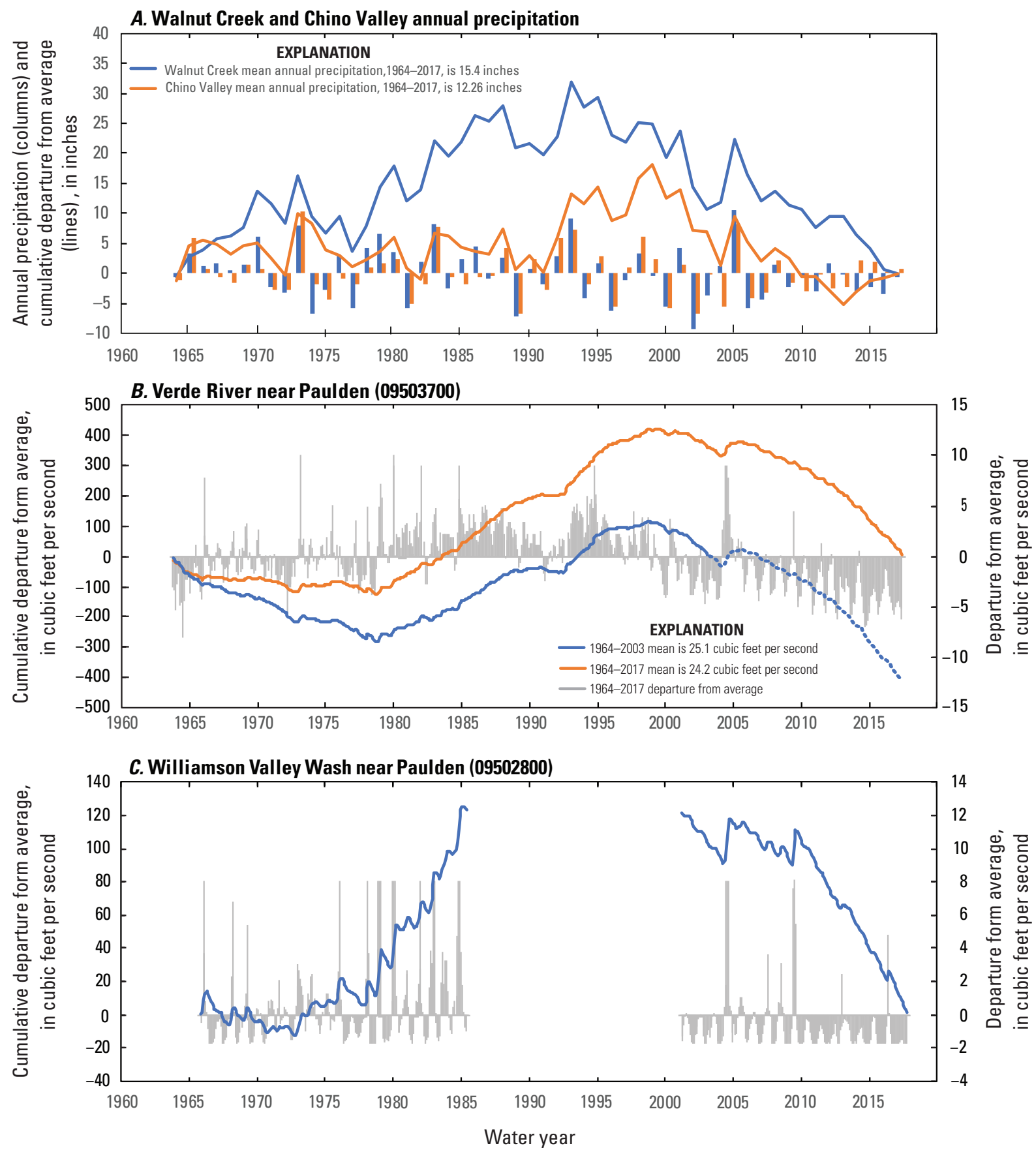

Figure 6. Graphs of mean annual precipitation and monthly base flow for U.S. Geological Survey streamgaging stations Verde River near Paulden (09503700) and Williamson Valley Wash near Paulden (09502800) in the Big Chino Subbasin in north-central Arizona. $A$, Time series showing mean annual (water year) precipitation and departure from average. $B$ and $C$, Hydrographs showing monthly base flow determined using HYSEP software (Sloto and Crouse, 1996) and cumulative departure from average for Verde River near Paulden and Williamson Valley Wash near Paulden, respectively. Year is start (October 1 of previous year) of indicated water year (for example, October 1, 2009, for water year 2010). See figure 3 for station locations. 
Together, the precipitation and discharge records indicate declining groundwater storage in the region. Basin-floor and stream-channel recharge to the aquifer(s) contributing to base flow in the Verde River appears to occur only during periods of wetter-than-average rainfall, and many years likely have little or no recharge. Spring discharge (and base flow) is directly correlated with the volume of water in storage (Nathan and McMahon, 1990), and changes in storage cause changes in discharge from an aquifer (Barlow and Leake, 2012). No especially wet periods (such as winter 2004-2005) are present in the 2010-2017 record. The steady decline in base flow at the Verde River near Paulden gage represents a decline in groundwater storage, but the location of storage declines within the contributing aquifers cannot be determined from the discharge data alone.

\section{Groundwater Withdrawals}

Groundwater withdrawals for irrigation make up most of the groundwater pumpage in the Big Chino Subbasin (Pool and others, 2011). Groundwater withdrawals occur in three general areas-Paulden, Williamson Valley and Walnut Creek, and upper Big Chino Valley. Withdrawals in the Paulden area are primarily for stock and domestic uses with some limited irrigation and industrial use. Withdrawals in the Williamson Valley and Walnut Creek areas are primarily for irrigation, stock, and domestic uses. Withdrawals in the upper Big Chino Valley area are primarily for irrigation. Total withdrawals in the Paulden area are a few hundred acre-feet of water annually, with about 160 acre-ft delivered by commercial providers (Arizona Corporation Commission, 2018) and the remainder pumped through domestic and stock wells required by Arizona statute to pump 35 gallons per minute or less. The exact amount of pumping is not reported and unknown but is likely between 2 to 4 times that of commercial deliveries-the U.S. Census Bureau (2018) reported 1,845 households in 2010 in the Paulden census-designated place; 650 customer water-meter connections were reported in 2016 (Arizona Corporation Commission, 2018).

Groundwater pumpage for irrigation in the Big Chino Subbasin was monitored by the USGS Water Use Program during 2013-2016. Estimated annual groundwater use varied from 2,812 to 4,015 acre-ft during this period (table 2). Major crops included alfalfa, corn, oats, and sod. Irrigated acreage, and pumpage, was highest in 2013 and 2016 and somewhat lower in 2014 and 2015 (table 2). Although the total amount of irrigated acreage in 2013 and 2016 was nearly identical (1,715 and 1,719 acres, respectively), the amount of pumpage increased about 6.5 percent in 2016 relative to 2013 because more acreage was planted in alfalfa, a relatively water-intensive crop.

\section{Aquifer-Storage Change and Storage Properties}

Changes in storage are described by area, with monitoring locations grouped into four areas with similar trend- the Williamson Valley Wash area, the Paulden area, the area west of Big Chino Wash and east of the Juniper and Santa Maria Mountains, and the Big Chino Water Ranch area. Storage monitoring stations are identified by the collocated well name, for stations that are collocated with monitoring wells, or by a station name (table 1). These stations are also referenced by a number between 1 and 32. Additional groundwater-level data collected by ADWR at nonstorage-monitoring locations are incorporated in the discussion; these stations are identified by well name and not by number. Some stations (for example, 7 , 15 , and 16) exhibit large variability during the early part of the study (2010-2013). This variability likely represents instrumental noise and (or) site instability; these data are largely excluded from the interpretation that follows.

Changes in groundwater levels and aquifer storage were generally small at the monitored sites during the study period. The general trend is toward decreasing groundwater elevation and decreasing aquifer storage. This is likely in part a recession from the last major recharge event in winter 2004-2005 and may also reflect basin-wide reductions in precipitation and recharge. Where appropriate, linear trendlines were fit to the data to estimate the average rate of storage change and groundwater elevation change. The storage-change error bars in figures $7,9,11$, and 13 are about $\pm 0.47 \mathrm{ft}$ of water, or 6 $\mu \mathrm{Gal}$, and represent the total measurement uncertainty of the A-10 absolute-gravity meter used in the study (Schmerge and Frances, 2006).

\section{Williamson Valley Wash Area}

Groundwater in the Williamson Valley Wash area is stored within relatively thin alluvial fill and weathered granite aquifers at the eastern, southern, and western margins of the area, and within interbedded volcanic and sedimentary units in the central part and to the north toward Big Chino Wash. Gravity surveys indicate the thickness of the interbedded sedimentary and volcanic basin-fill units is greater than $3,000 \mathrm{ft}$ at their deepest and between 500 and 2,000 ft thick throughout much of the basin (Langenheim and others, 2005). Paleozoic limestone units are not found at the surface nor in well logs except for within a small area in the Sullivan Buttes.

Groundwater flow is toward the central axis of the basin and to the north toward Big Chino Wash. The main recharge area is at higher elevations on Granite Mountain to the south (Navarro, 2002). Most wells are located near Williamson Valley Wash or along tributary channels. Depths to groundwater vary from less than $5 \mathrm{ft}$ within the alluvial floodplain to greater than $200 \mathrm{ft}$ in upland areas. Long-term data from wells located near Williamson Valley Wash (fig. 7) show relatively stable groundwater levels, but with declines since the 1980s (B-16-04 14BB1/B-16-04 23BBA; these nearby stations were combined to extend the long period of record at the former station, both exhibit shallow groundwater levels between 0 and $8 \mathrm{ft}$ below land surface) and 1990s (B-16-0427BCB). These declines correspond both with decreased precipitation during the 2000s (fig. 6) and increasing residential development in the area as former ranches were subdivided for housing developments. Station B-16-04 27BCB, where depth-to-groundwater 
Table 2. Summary of irrigated acreage and groundwater withdrawals for the Big Chino Subbasin in north-central Arizona, calendar years 2013-2016.

\begin{tabular}{|c|c|c|c|c|c|c|c|c|c|c|}
\hline \multirow[b]{2}{*}{ Area } & \multicolumn{2}{|r|}{2013} & \multicolumn{2}{|r|}{2014} & \multicolumn{2}{|r|}{2015} & \multicolumn{2}{|r|}{2016} & \multicolumn{2}{|c|}{ Average } \\
\hline & Acreage & $\begin{array}{c}\text { Withdrawals, } \\
\text { in acre-feet }\end{array}$ & Acreage & $\begin{array}{l}\text { Withdrawals, } \\
\text { in acre-feet }\end{array}$ & Acreage & $\begin{array}{c}\text { Withdrawals, } \\
\text { in acre-feet }\end{array}$ & Acreage & $\begin{array}{l}\text { Withdrawals, } \\
\text { in acre-feet }\end{array}$ & Acreage & $\begin{array}{c}\text { Withdrawals, } \\
\text { in acre-feet }\end{array}$ \\
\hline $\begin{array}{l}\text { Upper } \\
\text { Big Chino } \\
\text { Valley }\end{array}$ & 719 & 1,758 & 670 & 1,379 & 528 & 1,110 & 753 & 1,916 & 66 & 1,541 \\
\hline $\begin{array}{l}\text { Walnut } \\
\text { Creek }\end{array}$ & 52 & 109 & 22 & 32 & 75 & 139 & 57 & 140 & 51 & 10 \\
\hline $\begin{array}{c}\text { Williamson } \\
\text { Valley }\end{array}$ & 743 & 1,402 & 674 & 1,040 & 618 & 1,076 & 47 & 1,592 & 696 & 1,277 \\
\hline Total & 1,715 & 3,773 & 1,663 & 3,323 & 1,449 & 2,812 & 1,719 & 4,015 & 1,636 & 3,481 \\
\hline
\end{tabular}

varies from 20.9 to $46.6 \mathrm{ft}$ below land surface, showed increases in groundwater elevation of $10 \mathrm{ft}$ or more in 2010 and 2017, likely related to channel recharge from flow in nearby Strickland Wash and possibly Williamson Valley Wash. The 2010 increase corresponded with higher-than-average base flow at the Williamson Valley Wash near Paulden gage, but the 2017 increase did not. Depth to water at station B-16-04 14BB1/B16-04 23BBA varies from 0 to $7.8 \mathrm{ft}$. Although this station also receives channel recharge, variations are less because the water table is close to the surface, and the potential volume for storing recharged water is smaller.

The six storage-monitoring stations in the Williamson Valley Wash area are in areas of stream-channel recharge (fig. 8). Stations 1 and 2 are 0.8 and 0.6 miles west of Mint Wash, respectively; stations 3 and 4 are 1.2 and 1.7 miles from Williamson Valley Wash, respectively, in a stretch of perennial flow; station 5 is 1.5 miles northeast of Williamson Valley Wash and 0.9 miles south of Hitt Wash, a tributary to the north. Station 6 is in a small tributary valley of Williamson Valley Wash. The four wells collocated with gravity stations $(1-3,6)$ are all shallow, $300 \mathrm{ft}$ or less, and likely screened over large intervals (table 3 ). All are equipped with low-capacity pumps or windmills and are pumped regularly but not continuously. Driller's logs at stations B-15-03 11DDB (station 1) and B-16-03 17DAD (station 2) indicate wells were drilled in weathered granite and granite, but stations 3-6, farther to the west, are in areas of relatively thick basin fill, 1,000 feet or more, with layered Tertiary volcanic and sedimentary units (Langenheim and others, 2005).

Stations 1, 2, and 3 show relatively good agreement between groundwater levels and storage change. The relation is best at station 1, where the aquifer is formed in weathered granite. The relation at station 2 is less clear, because low groundwater levels measured in 2014 are not correlated with low gravity. However, the relatively large gravity changes indicate the presence of storage changes in an unconfined aquifer. The early part of the record at station 2, from 2002 to 2007, was collected by the National Geodetic Survey using an FG-5 absolute gravity meter, which has greater precision than the A-10 absolute gravity meter. The 2004-2005 recharge event is clearly visible and resulted in a $1.5 \mathrm{ft}$ increase in storage. At station 3, about 2,360 acre-ft of flow in Williamson Valley Wash from July 20, 2013, to February 26, 2014, (the date of a gravity measurement) caused a nearly $2 \mathrm{ft}$ increase in storage. This increase caused a small but short-lived increase in base flow at the Williamson Valley Wash streamgaging station (fig. 6; much of this flow was during two large, short stormflow events, which were removed from the base flow record in fig. 6 as part of the base flow separation analysis). Since then, both station 3 and 4 show steady declines in storage, -0.19 and -0.20 feet per year (ft/yr), respectively, the result of well withdrawals and base flow discharge to the nearby stretch of Williamson Valley Wash. Station 5 shows variable storage changes. A 1-ft increase in storage in winter 2017 may be associated with higher than average rainfall. However, there is a water-supply well (not monitored) and an earthen stock tank within 300 feet of the station, and on occasion the well was observed to overflow onto the land surface. Therefore, the storage-change record may reflect both nearsurface changes and deeper aquifer changes. Storage changes at station 6 are small, with a slight upward trend $(0.07 \mathrm{ft} / \mathrm{yr})$, whereas depth-to-groundwater typically has varied by several feet between measurements.

The relation between storage change and groundwaterlevel change at stations 1,3 , and 6 is linear, indicating unconfined conditions in the monitored aquifer (fig. 9). The estimated specific yield is $0.26,0.24$, and 0.04 , respectively (table 3 ). The relatively high values at stations 1 and 3 are consistent with a coarse-grained aquifer derived from weathered granite. Storage changes at station 6 result in a low estimate for specific yield, 0.04. However, water levels at this well were observed to vary widely and rapidly in response to the pumping rate of the windmill installed on the well; large drawdown in response to pumping indicates low hydraulic conductivity, the water levels may not represent static conditions in the aquifer, and the horizontal-infinite slab approximation used to convert gravity change to storage change may not be appropriate. 


\section{EXPLANATION}

- Aquifer-storage (repeat microgravity) station

- Monitoring well with long-term record

$\Delta 09502800$ Williamson Valley Wash near Paulden AZ streamgaging station

Monitoring well time-series data

$\rightarrow$ B-16-04 14BB1/B-16-04 23BBA

$\therefore$ B-16-04 27BCB
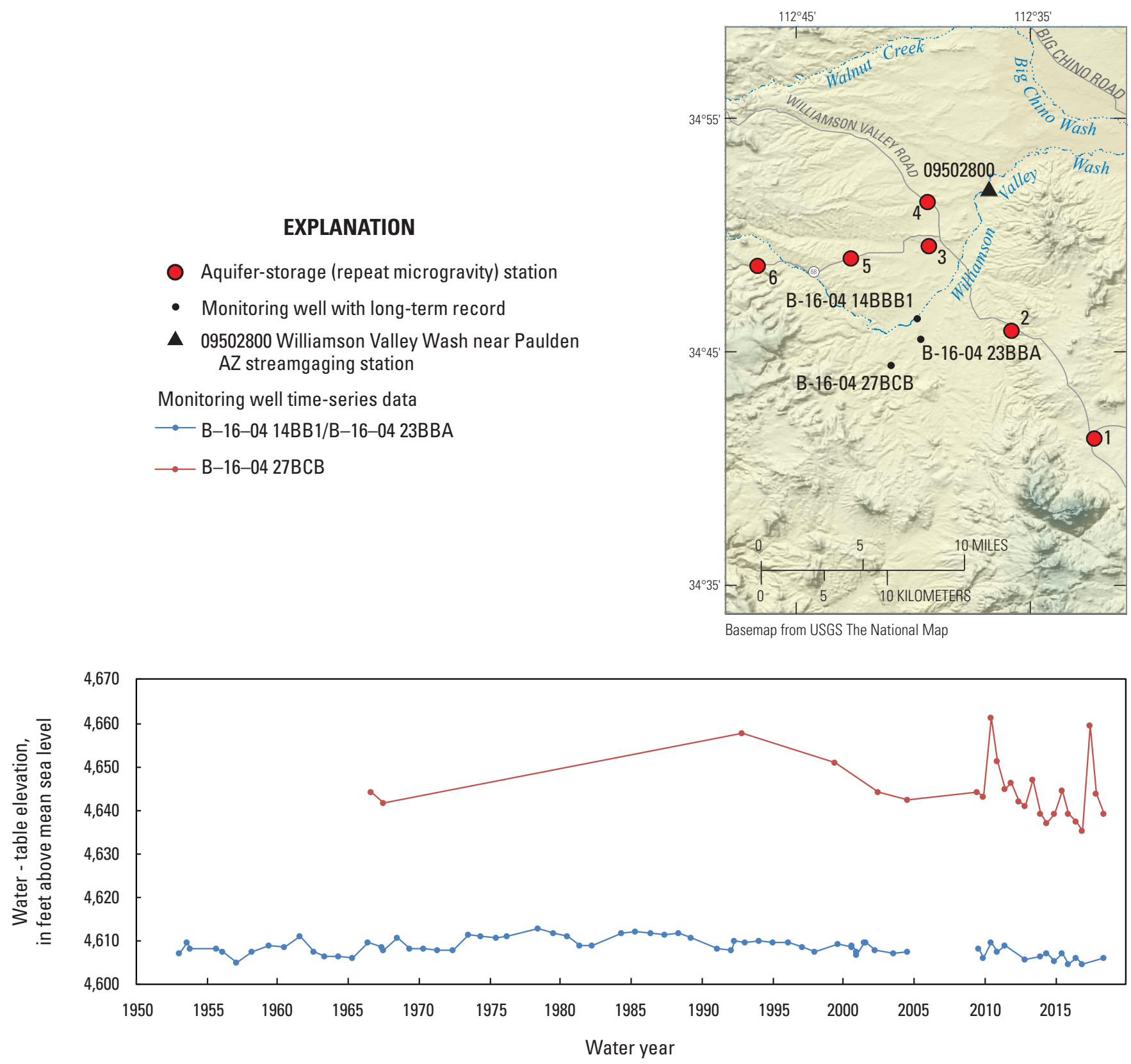

Figure 7. Index map and hydrograph showing long-term groundwater levels at two wells in the Williamson Valley Wash area of the Big Chino Subbasin in north-central Arizona. The blue line is a composite of the record at station B-16-04 14 BBB1 (before 2005) and station B-16-04 23BBA (after 2005). Year is start (0ctober 1 of previous year) of indicated water year (for example, October 1, 2009, for water year 2010). See table 1 for explanation of station numbers. See figure 3 for complete map of station locations.

\section{Paulden Area}

Groundwater wells in the Paulden area are generally finished within unconsolidated sedimentary, interbedded volcanic units (primarily basalt), or both. One well, B-18-02 28ABA (9) appears to be screened in Paleozoic limestone (the drillers' log indicates "gray rock" below $193 \mathrm{ft}$ depth). This part of the subbasin is bounded by the Sullivan Buttes and associated Tertiary volcanics to the south; Tertiary volcanics, Paleozoic limestone, and Precambrian igneous units to the east; and the
Big Chino Fault and Paleozoic limestone units to the north. The interbedded sedimentary/volcanic units in the Paulden area range from $600 \mathrm{ft}$ to more than $1,000 \mathrm{ft}$ (Langenheim and others, 2005). Most of the area is likely underlain by Paleozoic carbonate aquifer formations.

Groundwater flow in the Paulden area is generally northwest to southeast. All Paulden area well data are from unpumped wells originally constructed as production wells. Groundwater levels at wells with long-term records reached a maximum elevation in the late 1990s and declined from the 
Table 3. Screened interval, specific yield, and groundwater-storage trends in the Big Chino Subbasin of north-central Arizona.

[NA, not applicable, because station is not collocated with a monitoring well; --, no data]

\begin{tabular}{|c|c|c|c|c|}
\hline $\begin{array}{l}\text { Station } \\
\text { number }\end{array}$ & Station ID & $\begin{array}{l}\text { Screened interval, in feet below land } \\
\text { surface }^{1}\end{array}$ & $\begin{array}{l}\text { Specific } \\
\text { yield }\end{array}$ & $\begin{array}{l}\text { Change in storage, in feet of } \\
\text { free-standing water per year }\end{array}$ \\
\hline \multicolumn{5}{|c|}{ Williamson Valley Wash area } \\
\hline 1 & B-15-03 11DDB & $200-300$ & 0.23 & -- \\
\hline 2 & B-16-03 17DAD & $97-257$ & -- & -- \\
\hline 3 & B-17-04 26DBC & 200 & 0.24 & -0.19 \\
\hline 4 & WILLIAMSON VALLEY ROAD & NA & -- & -0.20 \\
\hline 5 & CAMP WOOD 2 & NA & -- & -- \\
\hline 6 & B-17-05 34DBA1 & 185 & 0.04 & 0.07 \\
\hline \multicolumn{5}{|c|}{ Paulden area } \\
\hline 7 & B-17-02 04DBC1 PZ1 & $377-417$ & -- & -- \\
\hline 7 & B-17-02 04DBC1 PZ2 & $209-249$ & -- & -- \\
\hline 7 & B-17-02 04DBC1 PZ3 & $130-170$ & -- & -- \\
\hline 8 & PAULDEN AA & NA & -- & -- \\
\hline 9 & B-18-02 28ABA & $241-384$ & 0.12 & -0.06 \\
\hline 10 & B-18-02 20DBB & $298^{3}$ & -- & -0.44 \\
\hline 11 & CHINO VALLEY SOUTH & NA & -- & -- \\
\hline 12 & B-17-02 06BBB & 342 & -- & -- \\
\hline 13 & B-18-02 31BCB & $15-320$ & -- & -0.36 \\
\hline 14 & B-18-03 26BBC & $133^{3}$ & 0.34 & -0.12 \\
\hline \multicolumn{5}{|c|}{ Area west of Big Chino Wash } \\
\hline 15 & B-18-04 25AAA2 & $515-735$ & -- & -- \\
\hline 16 & B-18-04 11ACC & $289-489$ & -- & -- \\
\hline 17 & B-18-04 01ACA2 & $500-1,000$ & -- & -- \\
\hline 18 & B-19-04 29DAB & unknown & -- & -- \\
\hline 19 & B-19-05 13BBA & unknown & -- & -- \\
\hline 20 & B-20-05 35DAD & unknown & -- & -- \\
\hline 21 & B-20-05 15CCC & unknown & -- & -- \\
\hline 22 & JUNIPER & NA & -- & -- \\
\hline \multicolumn{5}{|c|}{ Big Chino Water Ranch area } \\
\hline 23 & B-19-04 10CCB2 & $614-654$ & -- & -0.00015 \\
\hline 24 & B-19-04 09ACD & unknown & -- & -0.43 \\
\hline 25 & B-19-04 04CAC & 500 & -- & -0.24 \\
\hline 26 & B-19-04 05ABA & $900-1,140^{2}$ & -- & -0.09 \\
\hline 27 & B-20-04 33CBD2 & $100-160,310-400$ & -- & -0.07 \\
\hline 28 & B-20-04 32CAB & $223-485$ & -- & -0.33 \\
\hline 29 & B-20-04 32BBA & 602 & -- & -0.29 \\
\hline 30 & B-20-04 19CBA & 600 & -- & -0.07 \\
\hline 31 & B-20-04 18CDC & 630 & -- & -0.19 \\
\hline 32 & B-20-05 13DAA & 497 & -- & -- \\
\hline
\end{tabular}



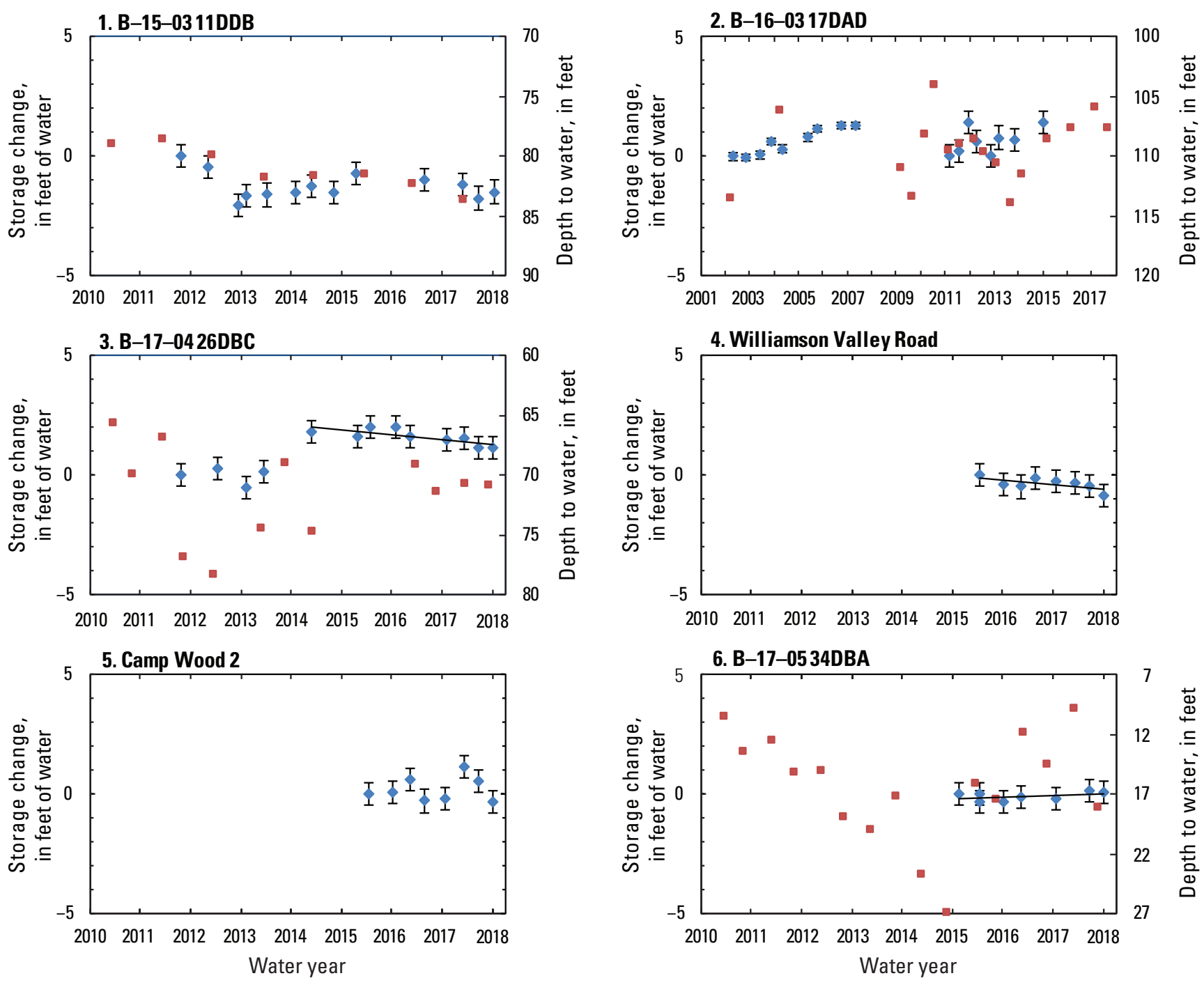

\section{EXPLANATION}

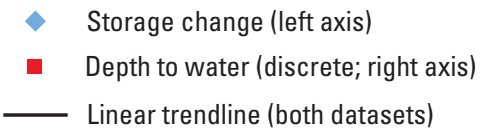

Figure 8. Graphs showing storage change and groundwater-level change (where applicable) by water year at stations 1 through 6 in the Williamson Valley Wash area of the Big Chino Subbasin in north-central Arizona. Year is start (October 1 of previous year) of indicated water year (for example, October 1, 2009, for water year 2010).

See table 1 for explanation of station numbers. See figure 7 for index map of station locations.

early 2000s to present (fig. 10), similar to the time series of monthly base flow (fig. 6). The most recent two winters with significant precipitation, 1993-1994 and 2004-2005, produced groundwater-level rises of about $4 \mathrm{ft}$ at well B-17-02 06BBB (station 12; 1993-1994 data are unavailable at other stations). Groundwater levels at this station, and others near ephemeral channels, rise primarily from in-channel infiltration of streamflow as compared to off-channel, land-surface infiltration. The 2004-2005 recharge event is clearly visible in all four records (fig. 10), even at well B-18-02 28ABA (station 9), 2.3 miles north of Big Chino Wash. The period of rising groundwater levels at well B-17-02 06BBB (station 12) from the 1970s to late 1990s corresponds with both wetter-than-average climate and decreasing groundwater withdrawals for irrigation in the Big Chino Subbasin, and the post-2000 period corresponds with drier climate and increasing groundwater withdrawals. Therefore, it is difficult to identify the relative importance of climate and groundwater withdrawals on groundwater storage at this location.

Eight storage-monitoring stations are in the Paulden area (fig. 10). They are the closest stations to the upper Verde River springs, and representative of the aquifer(s) most closely connected to the springs. Wells vary from 320 to $417 \mathrm{ft}$ depth (table 3). Where known, screened intervals in wells are 
generally long and may cross multiple aquifer units. Stations nearest to Williamson Valley Wash and Big Chino Wash (stations $7,8,11,12$ ), show small, variable changes in storage, without a clear trend, whereas stations away from the washes (stations 9, 10, 13, 14) all show steady declines in water levels and storage (fig. 11). Large storage changes (increases and decreases) at stations 7, 11, and 12 during periods of small, steady declines in water level indicates that these wells represent a deeper confined or semiconfined aquifer, rather than the uppermost water-table aquifer. Further evidence for a confined or semiconfined aquifer at these locations comes from
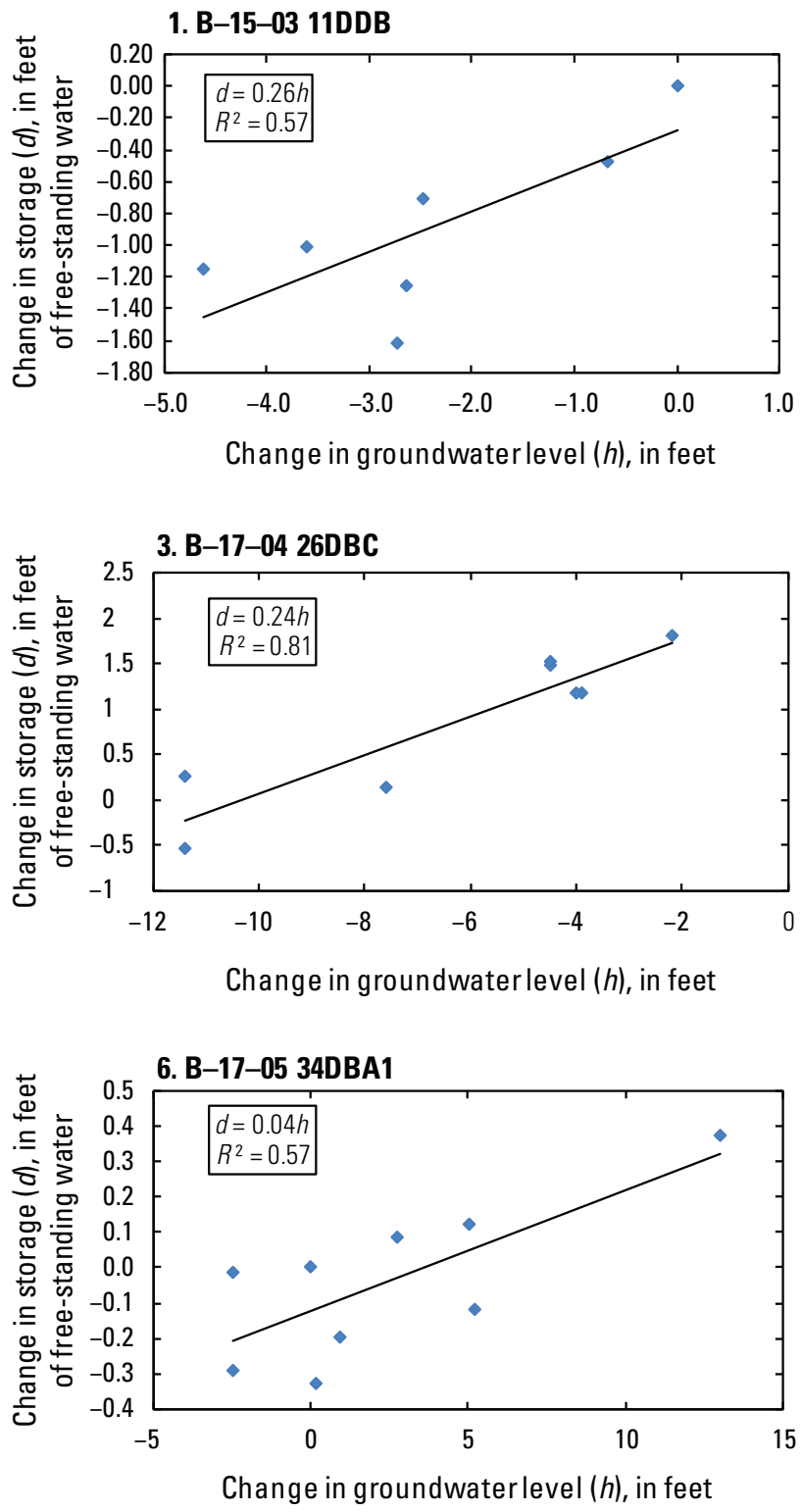

Figure 9. Scatter-plots showing the relation between changes in groundwater storage ( $d$; determined from repeat microgravity data) and changes in groundwater level $(h)$ at stations 1,3 , and 6 in the Williamson Valley Wash area of the Big Chino Subbasin in north-central Arizona. For an unconfined aquifer, the storage coefficient, or specific yield, is equal to the slope of the best-fit line. $R^{2}$, coefficient of determination. See table 1 for explanation of station numbers. See figure 7 for index map of station locations. the groundwater response to the 2004-2005 recharge event shown in fig. 10; in an unconfined aquifer, changes would be largest at the stations nearest the channels (stations 7 and 12) and smaller at farther away stations. Instead, the increase in water level, about $4 \mathrm{ft}$, is nearly identical at stations 7 and 12,350 and 1,150 ft from Big Chino Wash, respectively, as at well B-18-02 28ABA (station 9), 2.3 miles north of Big Chino Wash. Groundwater levels at three nested piezometers (smalldiameter monitoring wells installed at different depths within a single, larger-diameter borehole) at station 7 are identical to within about 0.2 feet and lack a consistent difference between piezometers (at different times, different piezometers have the highest and (or) lowest heads). This lack of variation between piezometers indicates minimal vertical gradients and therefore minimal vertical flow, suggesting all three piezometers are in the same aquifer unit or that their respective aquifers are wellconnected. Alternatively, the lack of variation may indicated failed seals between the different piezometers such that they all represent an average hydraulic head.

Stations 11 and 12 were established 0.1 and 0.2 miles north of Williamson Valley Wash, respectively, to monitor storage changes from recharge in the ephemeral channel. There were only three periods of flow greater than $100 \mathrm{ft}^{3} / \mathrm{s}$ during the study period-in summer 2013, winter 2015, and winter 2017. Only the winter-2015 event appeared to provide recharge to the uppermost unconfined aquifer, based on elevated gravity measurements at stations 7 and 12 . This increase in storage was short-lived, as gravity measurements returned to their previous level by the following fall. A larger flow event in winter 2017, during which about 4,700 acre-ft of flow passed the Williamson Valley Wash near Paulden (09502800) streamgaging station, did not produce noticeable recharge at any of the stations in the Paulden area, even though much of the flow infiltrated before reaching Sullivan Dam (Salt River Project, written commun., 2017). This suggests high transmissivity in the lower Williamson Valley Wash/Paulden area as recharged water was quickly distributed throughout the aquifer rather than stored as a groundwater mound near the channel. Because of the lack of large flow events, the importance of the shallow unconfined aquifer and its connection to the deeper confined or semiconfined aquifer is difficult to assess, although the groundwater response to earlier, larger events such as 2004-2005 in wells screened in the confined or semiconfined aquifer does indicate such a connection.

The gravity record at Paulden (station 8) extends back to 2001, when measurements were first made by the National Geodetic Survey. Follow-up measurements by USGS in 2016-2017 show a small (about $0.75 \mathrm{ft}$ ) increase in storage over the intervening 15 years (fig. 11). Between 2001 and 2007 storage increased gradually by about $0.5 \mathrm{ft}$; the recharge event in 2004-2005 had only a small effect on groundwater storage, despite the short distance between the station and Big Chino Wash (0.8 miles). Groundwater levels at B-17-02 04DBC1 (0.7 miles to the southwest), the nearest well with data available, declined steadily by about $6.2 \mathrm{ft}$ total during this time. Other wells in the Paulden area declined a similar amount. The lack of correlation between groundwater levels 


\section{EXPLANATION}

- Aquifer-storage (repeat microgravity) station

- Monitoring well with long-term record

Monitoring-well time-series data (collocated microgravity station number in parentheses)

$\rightarrow$ B-17-02 20ABD

$\longrightarrow \mathrm{B}-17-0206 \mathrm{BBB}(12)$

$\because \mathrm{B}-18-0204 \mathrm{DBC} 1(7)$

$\longrightarrow \mathrm{B}-18-0228 \mathrm{ABA}(9)$

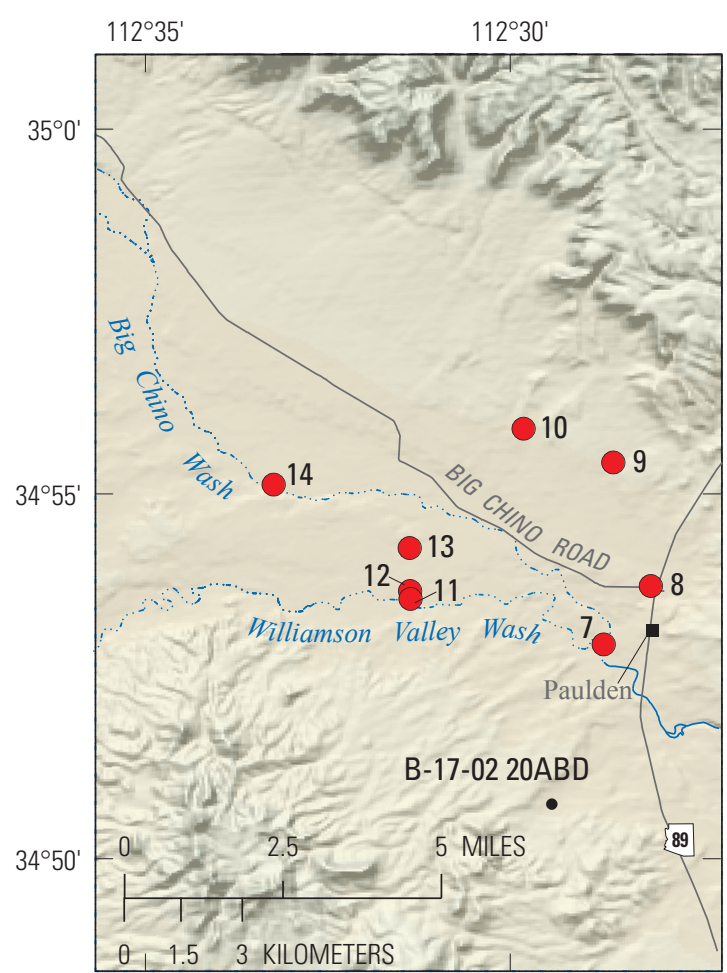

Basemap from USGS The National Map

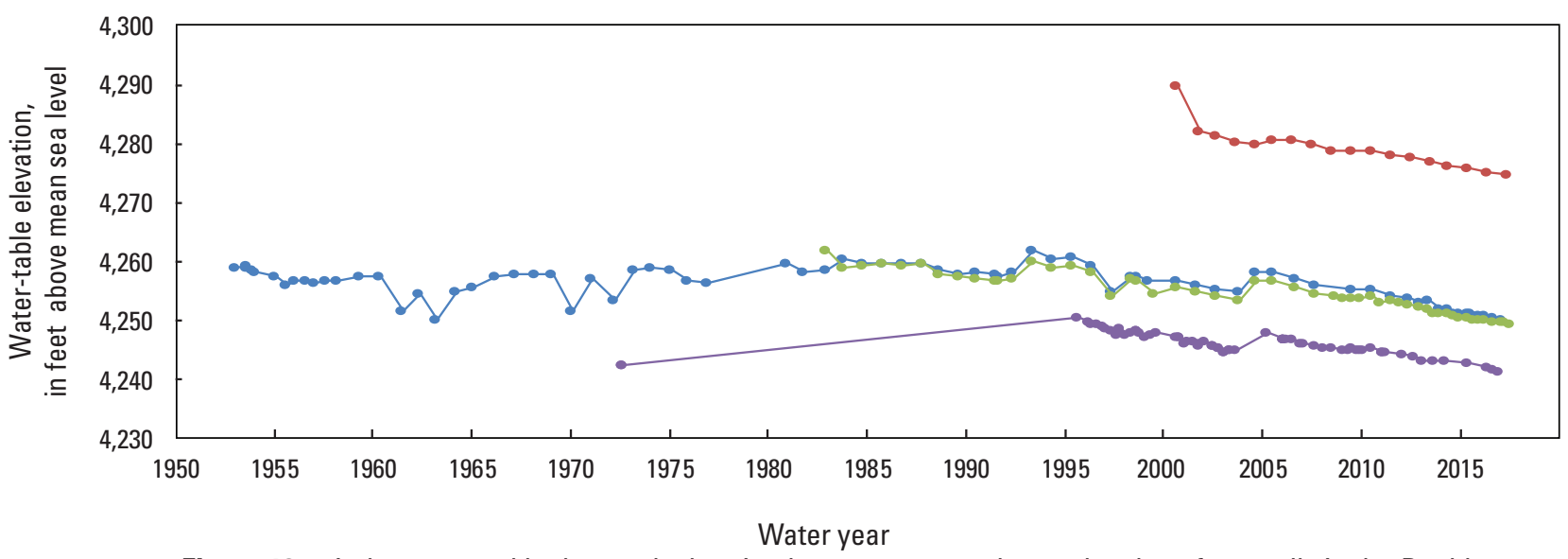

Figure 10. Index map and hydrograph showing long-term groundwater levels at four wells in the Paulden area of the Big Chino Subbasin in north-central Arizona. Year is start (October 1 of previous year) of indicated water year (for example, October 1, 2009, for water year 2010). See table 1 for explanation of station numbers. See figure 3 for complete map of station locations.

and storage change, combined with the small magnitude of storage change, indicates confined or semiconfined conditions in the monitored aquifer.

At two stations, stations 9 and 14, correlated decreasing trends in storage and groundwater level enabled specific-yield determinations of 0.12 and 0.34 , respectively (table 3). Correlated trends indicate unconfined conditions at both stations, but changes in groundwater storage were small and specific yield estimates have relatively high uncertainty. Station 9 is the nearest station to Paleozoic limestone units north of Paulden and is likely screened in limestone, although the screen is relatively long ( 241 to $384 \mathrm{ft}$ depth) and may intercept a deeper, confined or semiconfined aquifer(s) in addition to an uppermost unconfined aquifer. Station 14 is adjacent to Big Chino Wash; although the screened interval is unknown (total depth is $133 \mathrm{ft}$ ), it likely intercepts the uppermost unconfined aquifer.

\section{Area West of Big Chino Wash}

The area west of Big Chino Wash extends from south of Walnut Creek to the northern part of Big Chino Valley (Big Chino Wash extends an additional 40 miles northward). There is little development in this area, and groundwater withdrawals are for livestock and a few residences. Most wells are 300-800 ft deep and penetrate basin fill, possibly interbedded 
7. B-17-0204DBC1
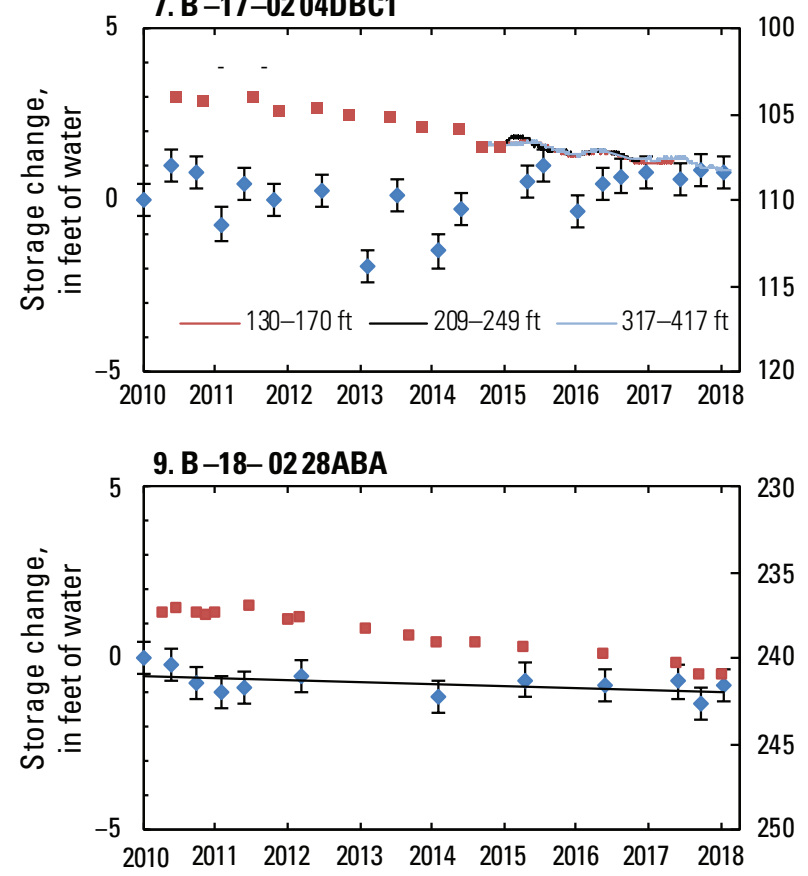

11. Chino Valley South

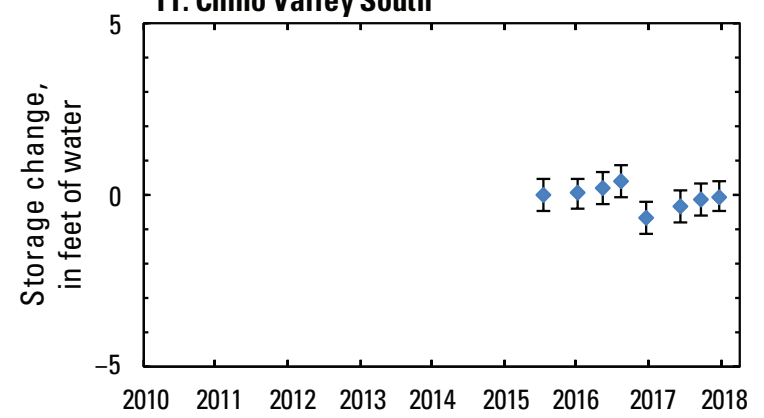

13. B-18-0231BCB

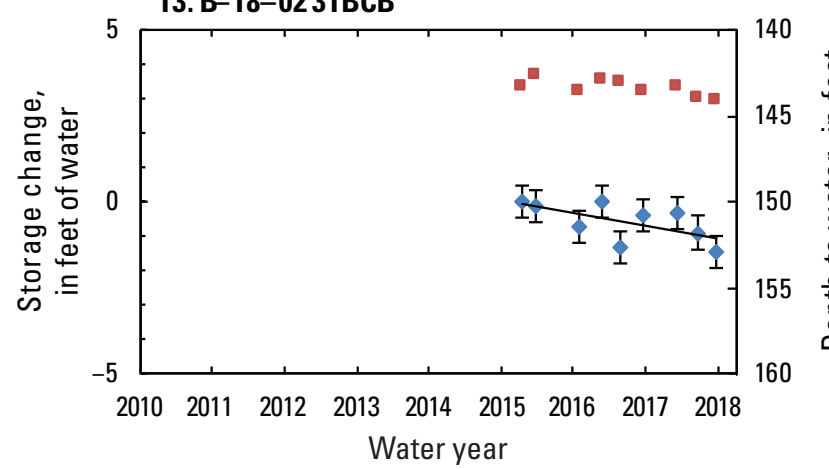

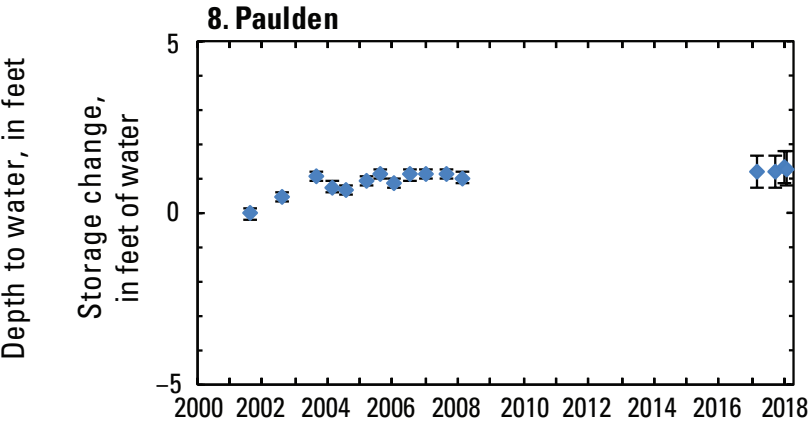
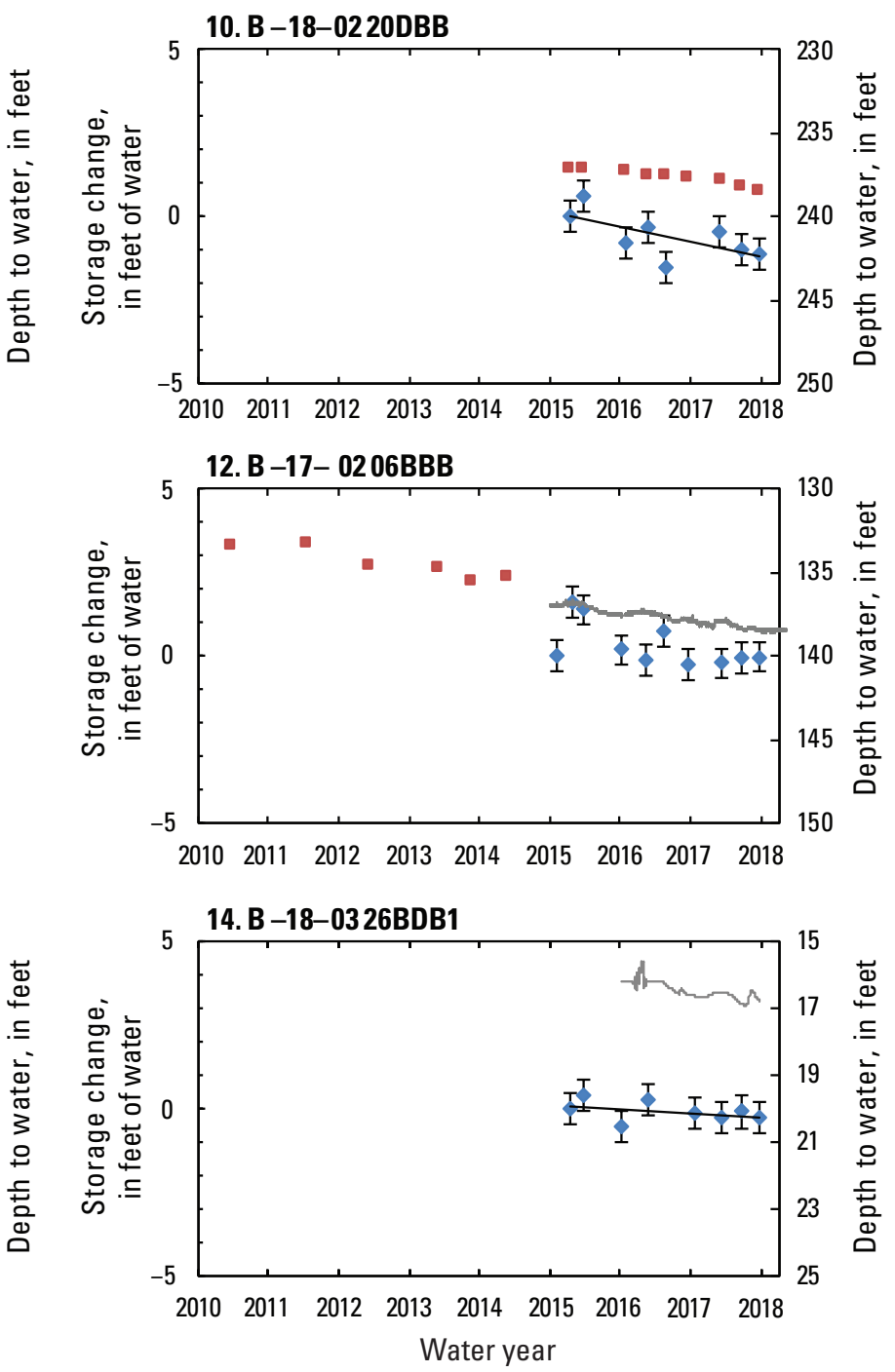

\section{EXPLANATION}

- Storage change (left axis)

- Depth to water (discrete; right axis)

— Linear trendline (both datasets)

Depth to water (continuous; right axis)

Figure 11. Graphs showing storage change and groundwater-level change (where applicable) by water year in the Paulden area of the Big Chino Subbasin in north-central Arizona. Year is start (October 1 of previous year) of indicated water year (for example, October 1, 2009, for water year 2010). See table 1 for explanation of station numbers. See figure 10 for index map of station locations. $\mathrm{ft}$, feet. 
with volcanic units, with some reaching Precambrian granite or other igneous rocks. Paleozoic units are rarely noted in well logs, although "dolomite" was encountered between 1,620 and $1,900 \mathrm{ft}$ depth in well B-18-04 01ACA1 (this well was backfilled; groundwater-level records are collected at the nearby well B-18-04 01ACA2; station 17). This likely represents a Paleozoic sedimentary unit or, because it is described as interbedded with a clay unit, simply a continuation of basin fill material. Wells in the area are generally old, few driller's logs exist, and well depths and construction are often unknown. There are extensive exposures of Paleozoic sedimentary units - primarily the Devonian Martin Formation and Cambrian Bright Angel Shale bounding the alluvial basin to the northwest - and scattered outcrops of Tertiary volcanic units throughout the area.

Groundwater flow in the area west of Big Chino Wash is generally west to east, from recharge zones at higher elevation in the Santa Maria and Juniper Mountains and along Walnut Creek, Pine Creek, and smaller tributaries of Big Chino Wash. Depths to groundwater are generally between 200 and $400 \mathrm{ft}$ below land surface. Most wells with groundwater-level data are equipped with small (5 horsepower gas, electric submersible, or windmill) pumps and are pumped intermittently. Little groundwater data are available from before the 1970s, and sufficient data collection for evaluating trends did not begin until the 1990s. Groundwater-level trends since the 1990s vary from steady declines in the southern part, to a gradual rise and fall of about $7 \mathrm{ft}$ over 12 years at B-19-05 13BBA in the central part, to small but steady increases in the northern part of the area west of Big Chino Wash (fig. 12). The 2004-2005 recharge event visible in the Williamson Valley Wash and Paulden Area records is apparent at two stations to the south (B-18-04 25AAA2 and B-19-04 27DBA), and is likely the cause of the rise in groundwater level at B-19-05 13BBA from 2006 to 2017, (regular groundwater data collection began in 2006), but channel recharge appears to have little influence on the two northernmost stations. At those stations, although the historical trend is positive, groundwater levels have flattened since 2016. In the context of recent trends at other wells in the area (discussed below in Groundwater-Level and Storage Trends), storage is likely unchanging or declining throughout the area.

Storage change is monitored at eight stations in the area west of Big Chino Wash (fig. 13). However, stations 18, 19, 20, and 21 have short records beginning in 2017; measurements indicate little or no storage change during 2017, but longer time series are required for further interpretation. At station 15, which is screened from 515-735 ft (the bottom 40 $\mathrm{ft}$ in granite), storage declined from the start of monitoring in 2010 until stabilizing in 2013 (table 3). The decline is likely due to prolonged drainage in the unsaturated zone following the 2004-2005 recharge event (fig. 11). The distinct breakpoint in the groundwater level in 2011 at this station and station 16, at which time groundwater levels start to decline, may indicate a change in the pumping regime at these or other nearby locations. At station 16, which also reached granite bedrock at 490 $\mathrm{ft}$ (screened from 289-489 ft), the storage-change record is noisy during the first half of the record and likely not representative of aquifer storage changes. Since 2014, storage follows a declining trend, except for an increase of about 1 $\mathrm{ft}$ between the spring and fall 2016 measurements; the cause of this increase is unknown, as only two relatively small flow events on nearby Walnut Creek occurred during summer 2016 (Salt River Project, written commun., 2017), and a similar increase is not seen at station 17, closer to Walnut Creek. Furthermore, larger, longer duration flow events during winter 2016-2017 did not produce a similar increase in storage. At station 17, screened from 500 to 1,000 ft depth, an anomalous shift occurred in 2015, when the groundwater level dropped by about $14 \mathrm{ft}$ between two automated measurements 6 hours apart. The cause of this shift is probably structural failure of the well and (or) annular material, and groundwater levels at this well may not represent the aquifer(s) intersecting the screened interval. On the basis of driller's logs, which describe multiple, thin (10 to $60 \mathrm{ft})$ interbedded units of clayey sand, sandy clay, and clay, there are likely multiple aquifers at this location. An increase in storage of nearly $2 \mathrm{ft}$ in 2017 is likely the result of runoff events in nearby Walnut Creek.

Station Juniper (station 22) is located on a Redwall Limestone outcrop in the foothills of the Juniper Mountains. Because the limestone is relatively impermeable compared to the alluvium at the surface at most other stations, there is little soil moisture signal and any storage changes should reflect the aquifer within the limestone aquifer. Compared to other stations in the area west of Big Chino Wash, this station shows relatively large changes, decreasing by about 1.6 $\mathrm{ft}$ from summer 2015 to winter 2016-2017, then increasing by a similar amount through fall 2017 , likely in response to winter 2016-2017 precipitation that caused flows throughout the region (Salt River Project, written commun., 2017). These changes indicate the presence of an unconfined aquifer within the limestone formation that responds rapidly to recharge, likely from direct precipitation in the surrounding area and at higher elevations in the Juniper Mountains to the west.

Storage-change and groundwater-level data from the area west of Big Chino Wash are largely uncorrelated, with steady declines in groundwater level of several feet during the study period accompanied by variable changes in storage. This indicates that groundwater levels are representative of a deeper, confined or semiconfined aquifer, whereas relatively large storage changes are occurring at the water table in an unconfined aquifer above the confined or semiconfined aquifer(s) and (or) in the unsaturated zone.

\section{Big Chino Water Ranch Area}

The BCWR overlies basin fill in the northwest part of the study area, about 15 miles northwest of Paulden (fig. 2). Depth to bedrock in the area is as much as $6,000 \mathrm{ft}$ (Langenheim and others, 2005), and the area contains the thickest basin-fill sequence in the study. The area is bounded on the northeast by the steeply dipping, normal Big Chino Fault, which emplaces low-porosity Precambrian igneous rocks adjacent to the basin fill material and likely serves as a barrier to groundwater flow 


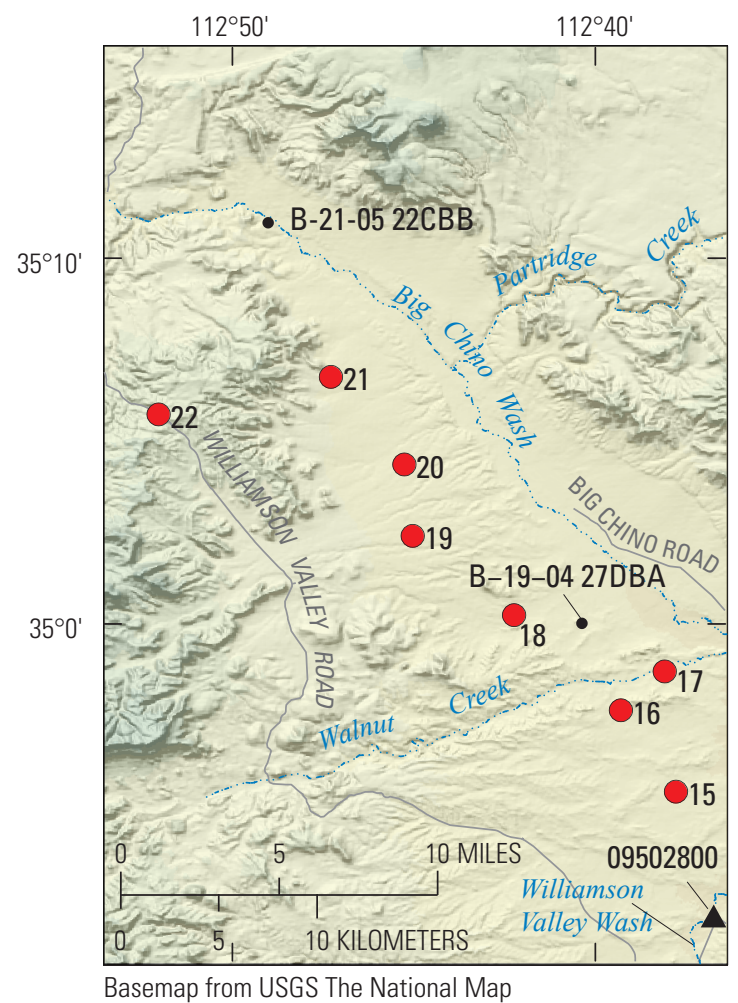

\section{EXPLANATION}

Aquifer-storage (repeat microgravity) station

- Monitoring well with long-term record

A 09502800 Williamson Valley Wash near Paulden AZ streamgaging station

Monitoring-well time-series data (collocated microgravity station number in parentheses)

$\longrightarrow$ B-19-05 13BBA (19)
$\rightarrow$ B-20-05 35DAD (20)
$\rightarrow$ B-21-05 22CBB
$\rightarrow$ B-19-04 27DBA
$\rightarrow$ B-18-04 25AAA2 (15)

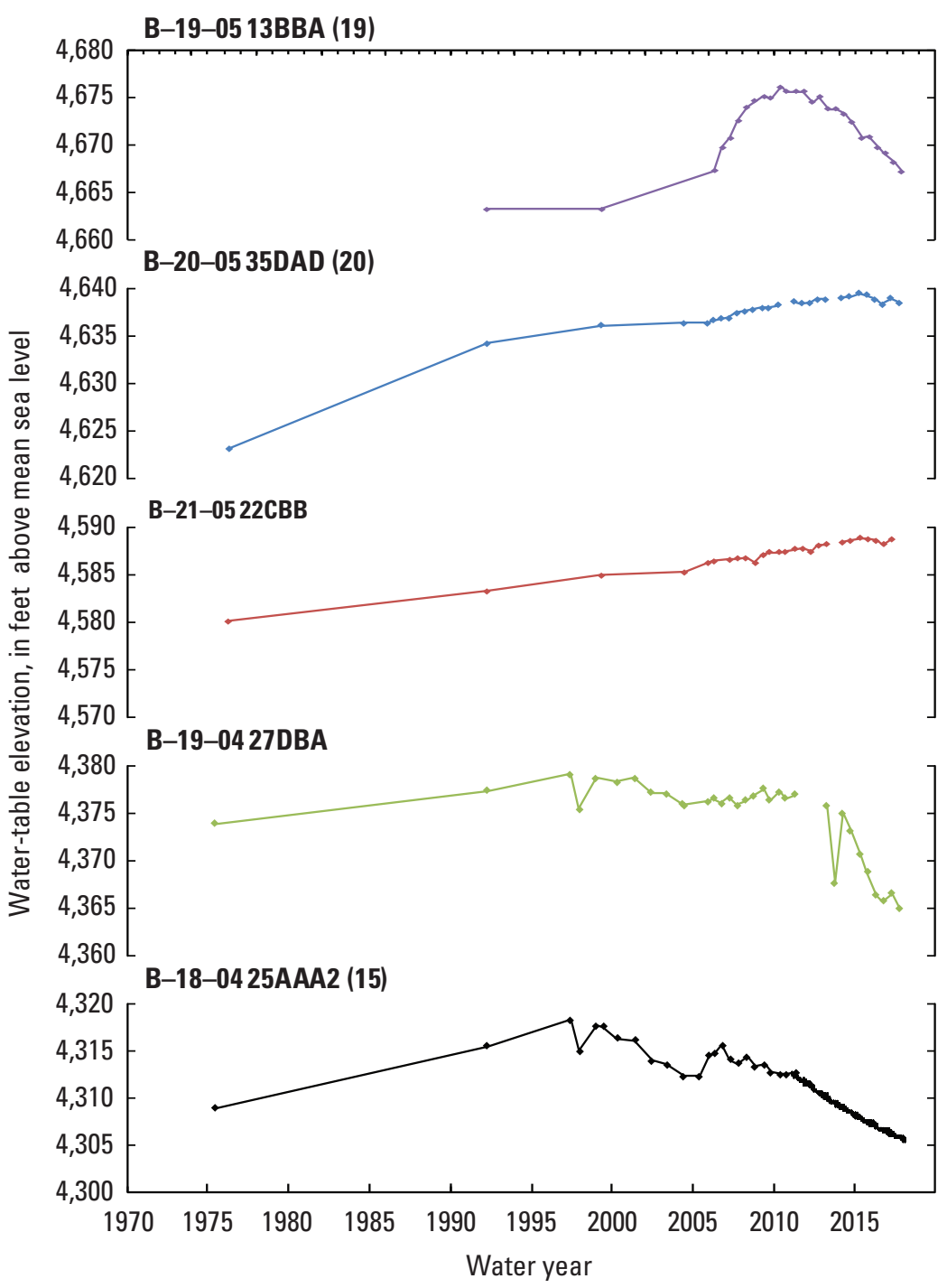

Figure 12. Index map and hydrographs showing groundwater levels in the area west of Big Chino Wash of the Big Chino Subbasin in north-central Arizona. Year is start (October 1 of previous year) of indicated water year (for example, 0 ctober 1,2009 , for water year 2010). See table 1 for explanation of station numbers. See figure 3 for complete map of station locations. to the northeast (Pool and others, 2011). Wells in the area monitored for this study are generally about $600 \mathrm{ft}$ deep (table 3). Driller's logs at B-19-04 10CCB2 (station 23), B-19-04 05ABA (station 26), and B-20-04 33CBD2 (station 27) (the only wells with logs available) indicate clay layers interbedded with coarser-grained units. Well B-19-04 10CCB2, and probably other wells of similar depth (stations 29, 30, 31, and 32 ), is screened in a basalt flow between 614 and $654 \mathrm{ft}$ below the land surface. Three wells were installed specifically for groundwater monitoring (B-19-04 10CCB2, B-20-04 33CBD2, and B-19-0405ABA). The remaining wells were installed as production wells for irrigation but are no longer pumped. Historically, the BCWR area contained the most irrigated acreage in the subbasin, and groundwater withdrawals peaked in the 1960s and 1970s (Blasch and others, 2006). When the ranch was purchased by the City of Prescott in 2004, irrigation was reduced and ended around 2010 (Southwest Groundwater Consultants, written commun., 2019). A small amount of pumping for irrigation, relative to 1970s levels, is ongoing on farmland that borders the BCWR to the northeast (Upper Big Chino Valley in table 2).

Groundwater flow in the BCWR area is generally northwest to southeast, although elevated water levels to the southwest at B-19-05 13BBA (fig. 12) indicate a northeastward gradient from the area west of Big Chino Wash. Groundwater levels have remained mostly steady, or increased, over time (fig. 14). Wells equipped with pressure transducers for continuous monitoring (fig. 15; stations 23, 26, 27) show rapid fluctuations in response to pumping; these fluctuations likely exist at other sites but are not visible with quarterly to annual 
15. B-18-04 25AAA2

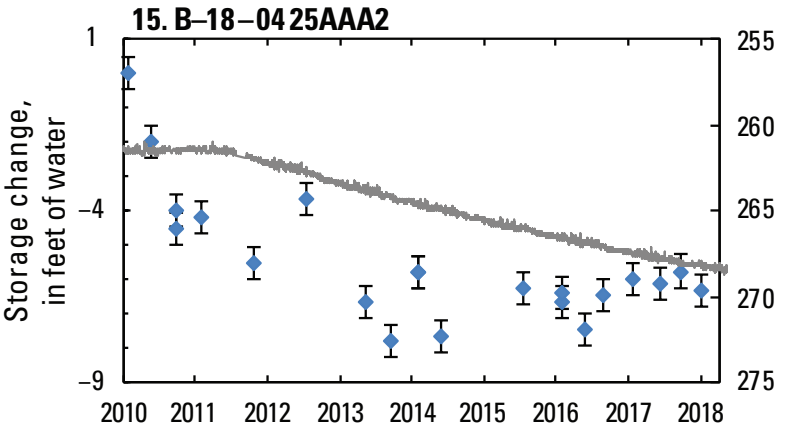

17. B-18-04 01ACA2
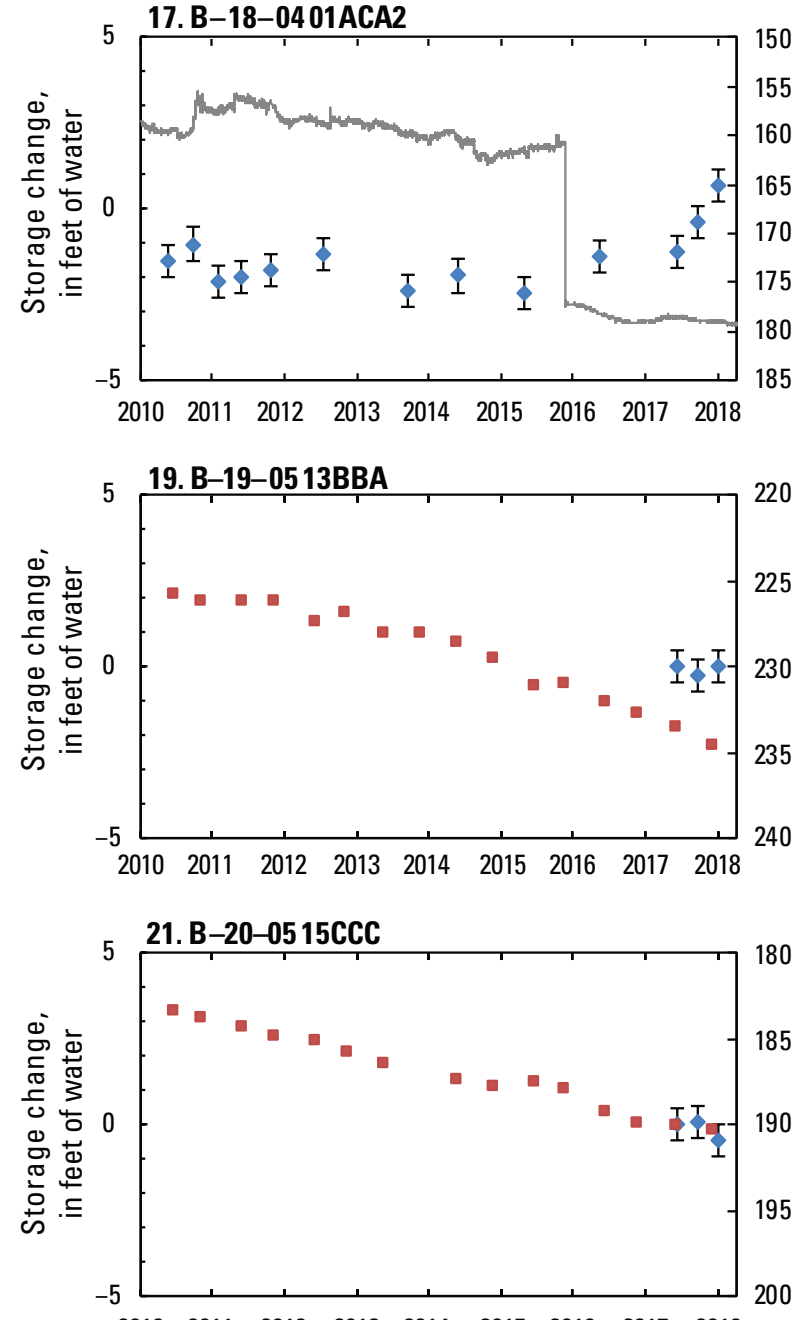

$201020112012 \quad 2013 \quad 2014 \quad 2015 \quad 2016 \quad 2017 \quad 2018$

Water year
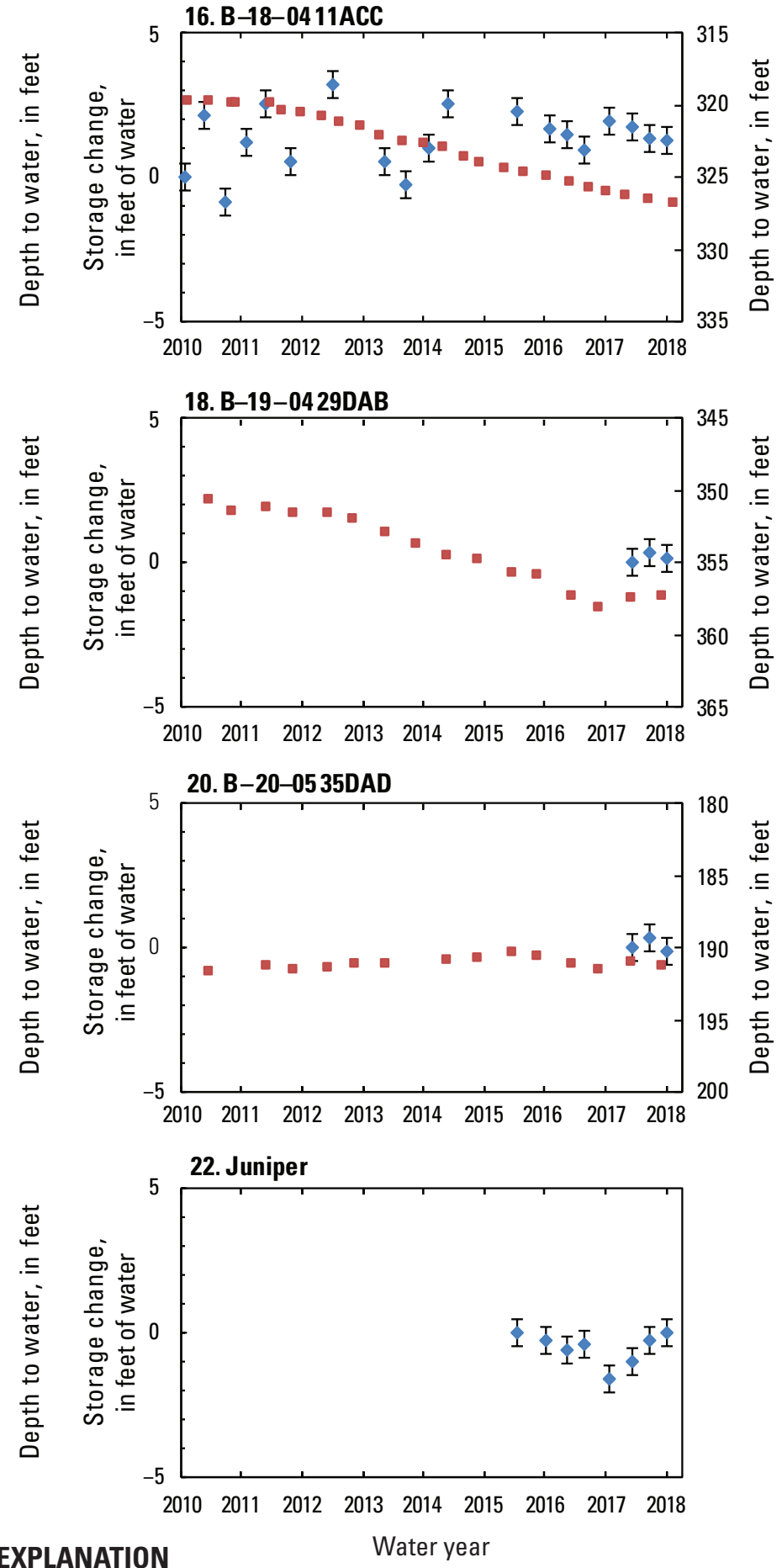

Storage change (left axis)

- Depth to water (discrete; right axis)

- Linear trendline (both datasets)

Depth to water (continuous; right axis)

Figure 13. Graphs showing storage change and groundwater-level change (where applicable) by water year in the area west of Big Chino Wash in the Big Chino Subbasin of north-central Arizona. See table 1 for explanation of station numbers. Year is start (October 1 of previous year) of indicated water year (for example, 0 ctober 1 , 2009 , for water year 2010). See table 1 for explanation of station numbers. See figure 12 for index map of station locations. 


\section{EXPLANATION}

Aquifer-storage (repeat microgravity) station

- Monitoring well with long-term record

A 09502800 Williamson Valley Wash near Paulden AZ streamgaging station

Monitoring-well time-series data (collocated microgravity station number in parentheses)

$\rightarrow$ B-20-05 13DAA (32)

-B-20-04 32BBA (29)

- B-19-04 04BDB

$\rightarrow$ B-19-04 10ADA

$\longrightarrow$ B-19-03 19CBD

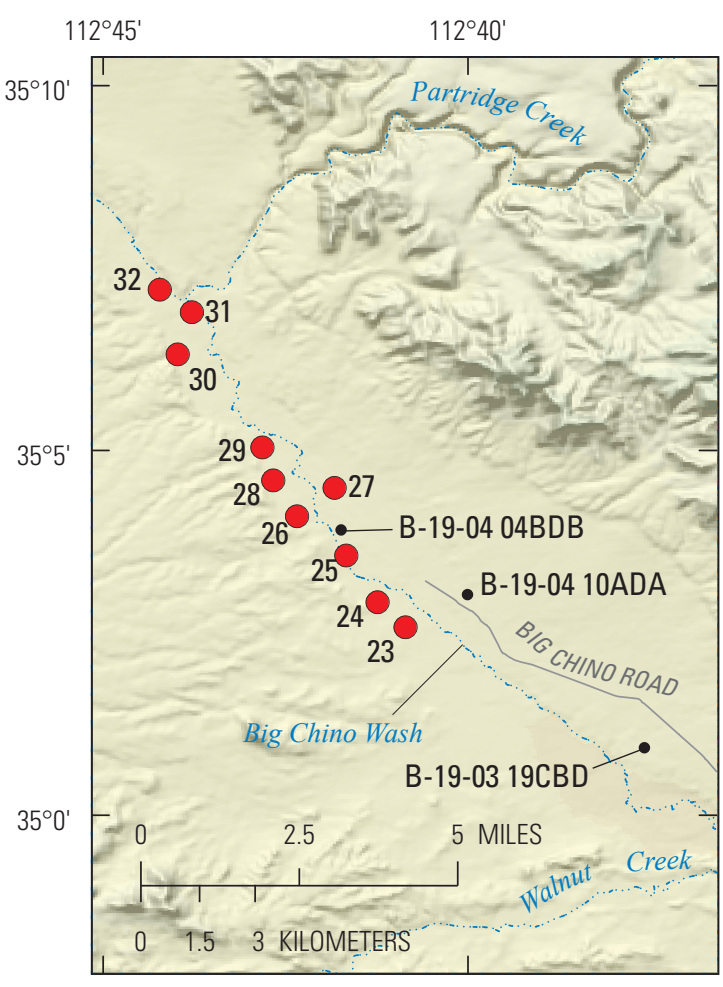

Basemap from USGS The National Map

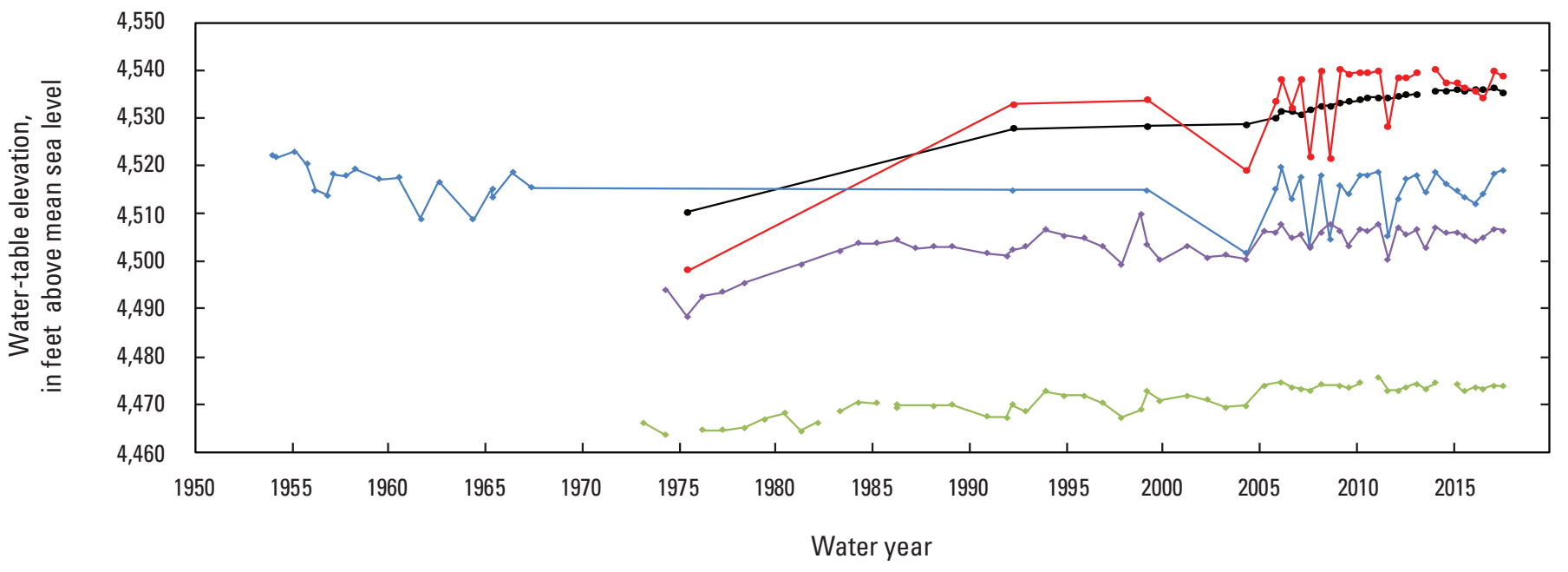

Figure 14. Index map and hydrographs showing groundwater levels in the area west of Big Chino Wash in the Big Chino Subbasin of north-central Arizona. Year is start (October 1 of previous year) of indic ated water year (for example, 0 ctober 1, 2009, for water year 2010). See table 1 for explanation of station numbers. See figure 3 for complete map of station locations. 

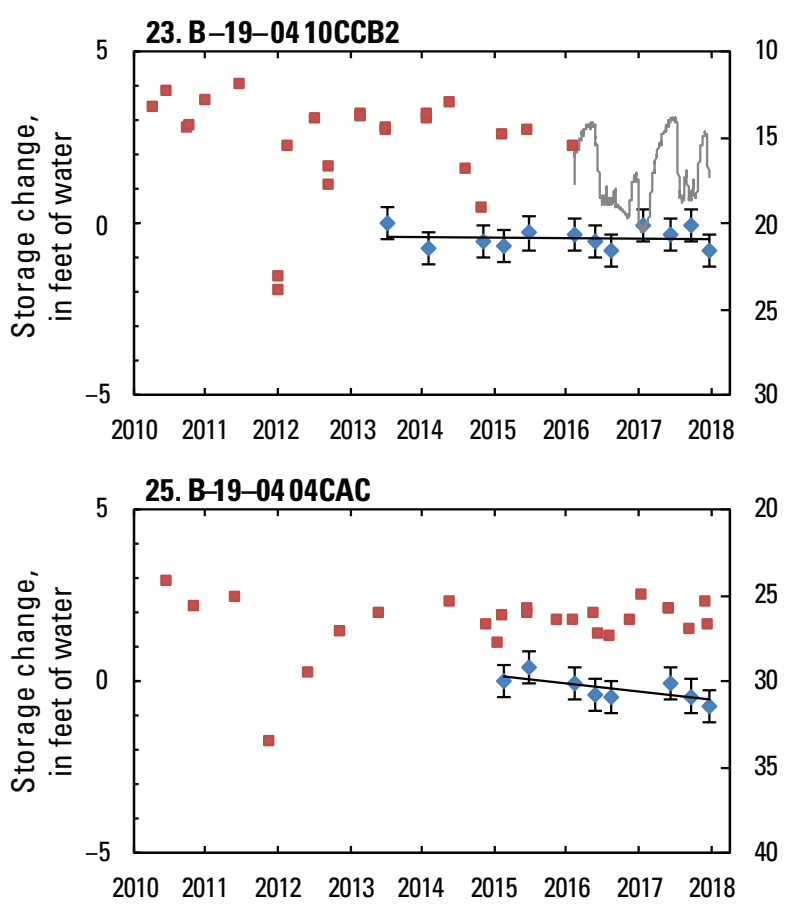

27. B-20-04 33CBD2
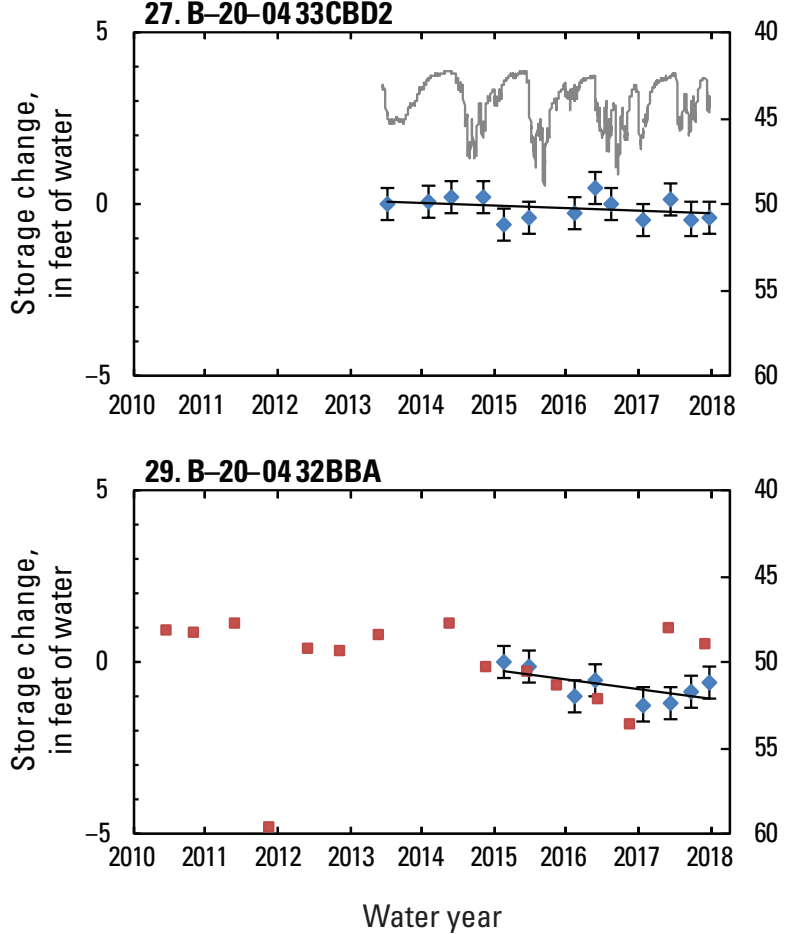
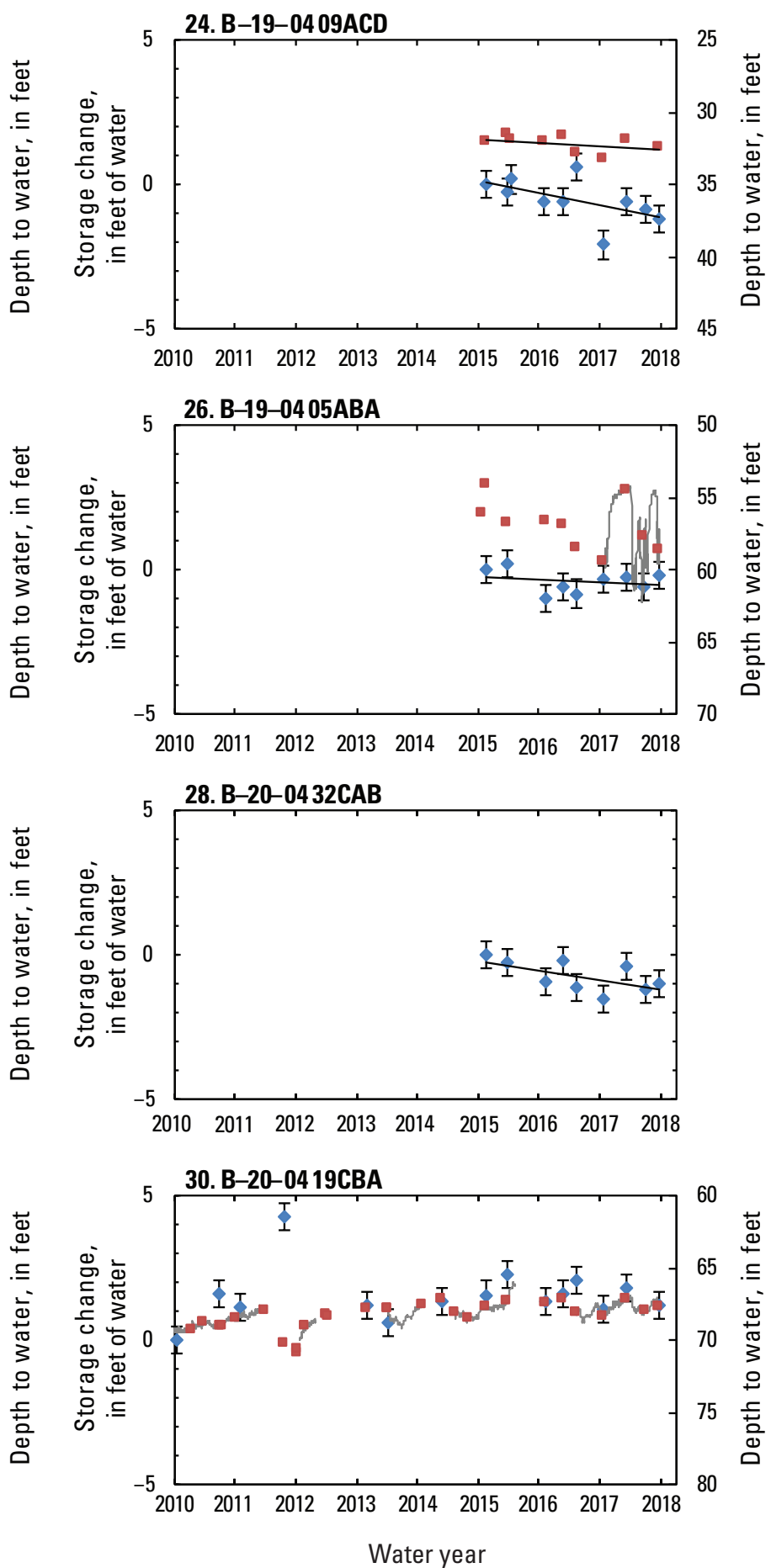

\section{EXPLANATION}

Storage change (left axis)

- Depth to water (discrete; right axis)

Linear trendline (both datasets)

Depth to water (continuous; right axis)

Figure 15. Graphs showing storage change and groundwater-level change (where applicable) by water year in the Big Chino Water Ranch area of the Big Chino Subbasin in north-central Arizona. Year is start (October 1 of previous year) of indicated water year (for example, October 1, 2009, for water year 2010). See table 1 for explanation of station numbers. See figure 14 for index map of station locations. 
31. B-20-04 18CDC

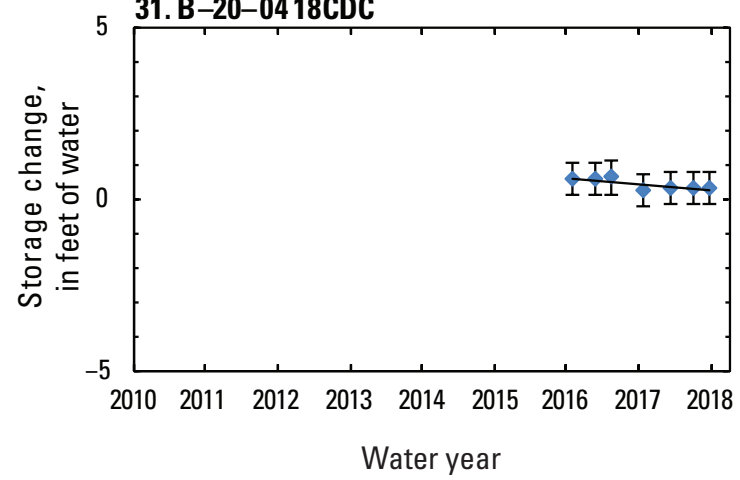

32. B-20-0513DAA

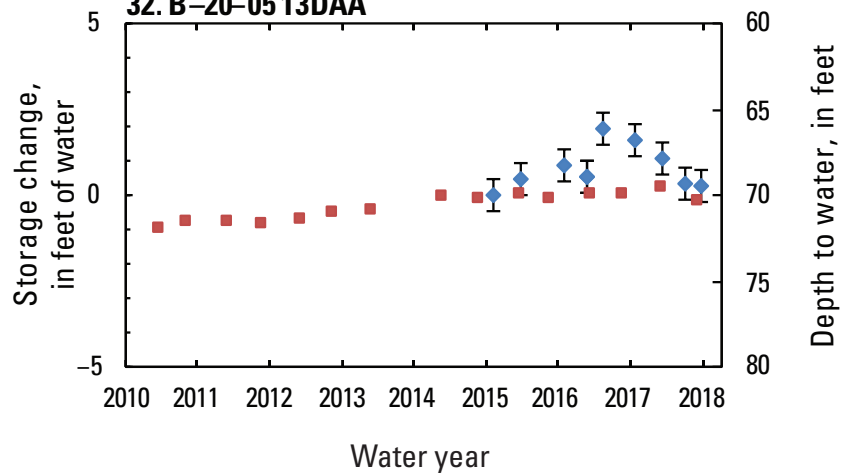

Figure 15. Graphs showing storage change and groundwater-level change (where applicable) by water year in the Big Chino Water Ranch area of the Big Chino Subbasin in north-central Arizona. Year is start (October 1 of previous year) of indicated water year (for example, 0 ctober 1, 2009, for water year 2010). See table 1 for explanation of station numbers. See figure 14 for index map of station locations.-Continued

groundwater-level monitoring. The persistent, steady increase in water levels at B-20-05 13DAA, B-19-04 10ADA, and B-19-03 19CBD (fig. 14) likely reflects decreased pumping for agriculture since the 1970s (Schwab, 1995). These wells are relatively far from present-day pumping and show smooth, quasi-linear trends. In contrast, wells B-20-04 32BBA and B-19-03 04BDB are closer to present day pumping and depth to water fluctuates with the amount of pumping. As in the other areas in the study, winter 2004-2005 was the most significant recharge event in recent years. Additional recharge appears to have occurred during winter 1994-1995, and in the late 1990s, based on the record at B-19-04 10ADA and B-1903 19CBD (fig. 14). Flows in Partridge Creek and Big Chino Wash in early 2017 (Salt River Project, written commun., 2017) did not result in any increase in groundwater levels.

Storage change is monitored at 10 stations in the BCWR area (fig. 15). At three sites with continuous records (stations $23,26,27)$, rapid groundwater-level changes caused by pumping are not reflected in the storage-change data, indicating confined or semiconfined conditions. Large fluctuations in storage are nearly absent; exceptions are two measurements (high and low) at station 24 and an increase in storage followed by a gradual decline at station 32 . The absence of fluctuations in storage indicates that any near-surface unconfined aquifer storage changes, or changes in storage in the unsaturated zone, are minimal. Storage changes may be small if significant clay accumulations are at or near the surface, as indicated by the driller's log at station 27. There are no shallow monitoring wells at the BCWR and near-surface aquifer conditions are unmonitored, except for the repeat microgravity measurements presented in this report.

Further qualitative evidence for confining conditions in the BCWR area is the speed with which pumping-induced groundwater-level fluctuations propagate through the aquifer (fig. 16). Confined aquifers (specifically, aquifers with high hydraulic diffusivity) propagate stresses faster than unconfined aquifers (Barlow and Leake, 2012). The signals recorded at wells B-19-04 10CCB2 (23), B-19-04 05ABA (26), and B-20-04 33CBD2 (27), all about 1.5 miles from the primary pumping well, but in different directions, record nearly identical signals, particularly with respect to the timing of water level changes. The same fluctuations are present in B-20-04 19CBA (30), about 4.5 miles up-valley. The magnitude of fluctuations at this well is much smaller (see fig. 7 for more detail), but the timing remains nearly identical to those at the other three wells. Water levels at these wells show a rapid increase in drawdown when pumping begins in spring (around April 1; fig. 16), followed by variable drawdown during the summer irrigation season. At the end of the irrigation season in the fall water levels gradually recover, reaching a maximum in mid-winter.

\section{Trends in Groundwater Levels and Aquifer Storage}

Trends in groundwater levels and storage allow for comparing groundwater conditions within and between areas. Statistical tests for linearity of groundwater elevation and trend in elevation indicated that wells can be divided into two main groups - (1) those that fluctuate at short time scales but without an obvious linear trend and (2) those with a linear trend that reflect aquifer processes over longer time scales. Wells in the study area in the ADWR Groundwater Site Inventory database (Arizona Department of Water Resources, 2018) with five or more measurements during the 2010-2017 period were considered (73 total; table 4). Thirty-five of these wells had groundwater-level records that were approximately linear and with a suggested trend (fig. 17). These were wells with a correlation coefficient greater than 0.75 and for which the null hypothesis that no trend exists was rejected using the Mann-Kendall trend test. These wells are located west of Big Chino Wash 
on alluvium extending east from the Santa Maria and Juniper Mountains, on the basin floor in the northern part of the BCWR area, and in the Paulden area. At an additional seven stations, a trend was suggested because the Mann-Kendal null hypothesis (no trend) was rejected, but the groundwater-level record was not sufficiently linear (correlation coefficient $<0.75$ ) to indicate a long-term trend. Finally, at 31 stations the record was nonlinear, and the Mann-Kendall null hypothesis was not rejected. These stations generally showed high variability in time and (or) were influenced by variation in pumping or recharge.

Groundwater-level trends were previously analyzed by ADWR for the periods 1999-2004 and 2004-2009 (Flora and others, 2009). Compared to the present study, which evaluated trends for consistency using at least five groundwater levels at each well, the ADWR analysis compared groundwater levels at the beginning of each period to the end of each period. During the 1999-2004 period, groundwater levels fell or remained the same at nearly every well throughout the study area (Flora and others, 2009). The main area of groundwater-level declines from 1999 to 2004 was along Big Chino Wash in the southern part of the BCWR, where several wells with a nonlinear record and no significant trend are clustered (fig. 16). During the 2004-2009 period, groundwater levels were nearly constant or increased throughout the study area, in large part in response to prolonged winter precipitation and runoff in 2004-2005. Combining the ADWR analysis (Flora and others, 2009) with data presented in this report shows that groundwater levels (and groundwater storage) away from Big Chino Wash tend to decline slowly except when punctuated by periods with exceptionally high precipitation and recharge, such as winter 2004-2005.

Trends in groundwater levels indicate increasing or decreasing storage, but do not quantify changes in storage. On the other hand, storage trends derived from gravity data are a quantitative measurement allowing comparison between stations. Gravity records indicated declining storage throughout much of the study area (fig. 18). Because gravity records cover a shorter time period and generally show more variability than water-level trends, the linearity test and Mann-Kendall trend test were considered unsuitable. Instead, each station was evaluated qualitatively for trends. Those where trends were identified are indicated by linear trendlines in the area timeseries plots (figs. 8, 11, 13, 15). Out of 16 stations determined to have quasi-linear trends, trends were negative at 15 stations - 9 in the Big Chino Water Ranch area, 4 in the Paulden area, and 2 in the Williamson Valley Wash area (table 3).

Storage trends were positive at just one station, in the western part of the Williamson Valley Wash area. Trends ranged from -0.44 to $0.07 \mathrm{ft}$ of water per year. A downward storage trend was identified at many of the stations in the valley bottom in the BCWR area, where groundwater levels indicated no trend. This may indicate delayed drainage from the unsaturated zone or from fine-grained and (or) perched aquifers in response to recharge from overbank flooding (such flooding was observed in 2013, at the start of gravity data collection in the area). No trend in storage was identified at many of the stations in the area west of Big Chino Wash, although several of these stations have short records and trends may not yet be apparent.

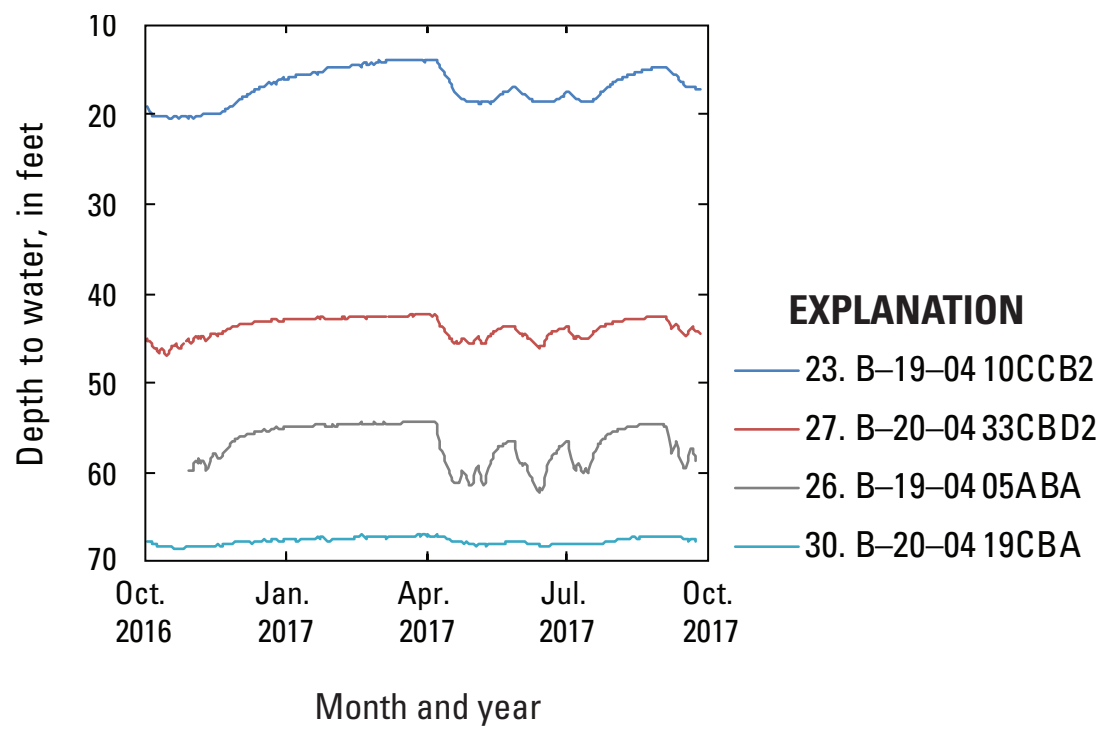

Figure 16. Graph showing rapid propagation of pumping-induced groundwater-level changes at four wells in the Big Chino Water Ranch area in the Big Chino Subbasin in north-central Arizona. Month is first day of indicated month. See table 1 for explanation of station numbers. See figure 14 for index map of station locations. 


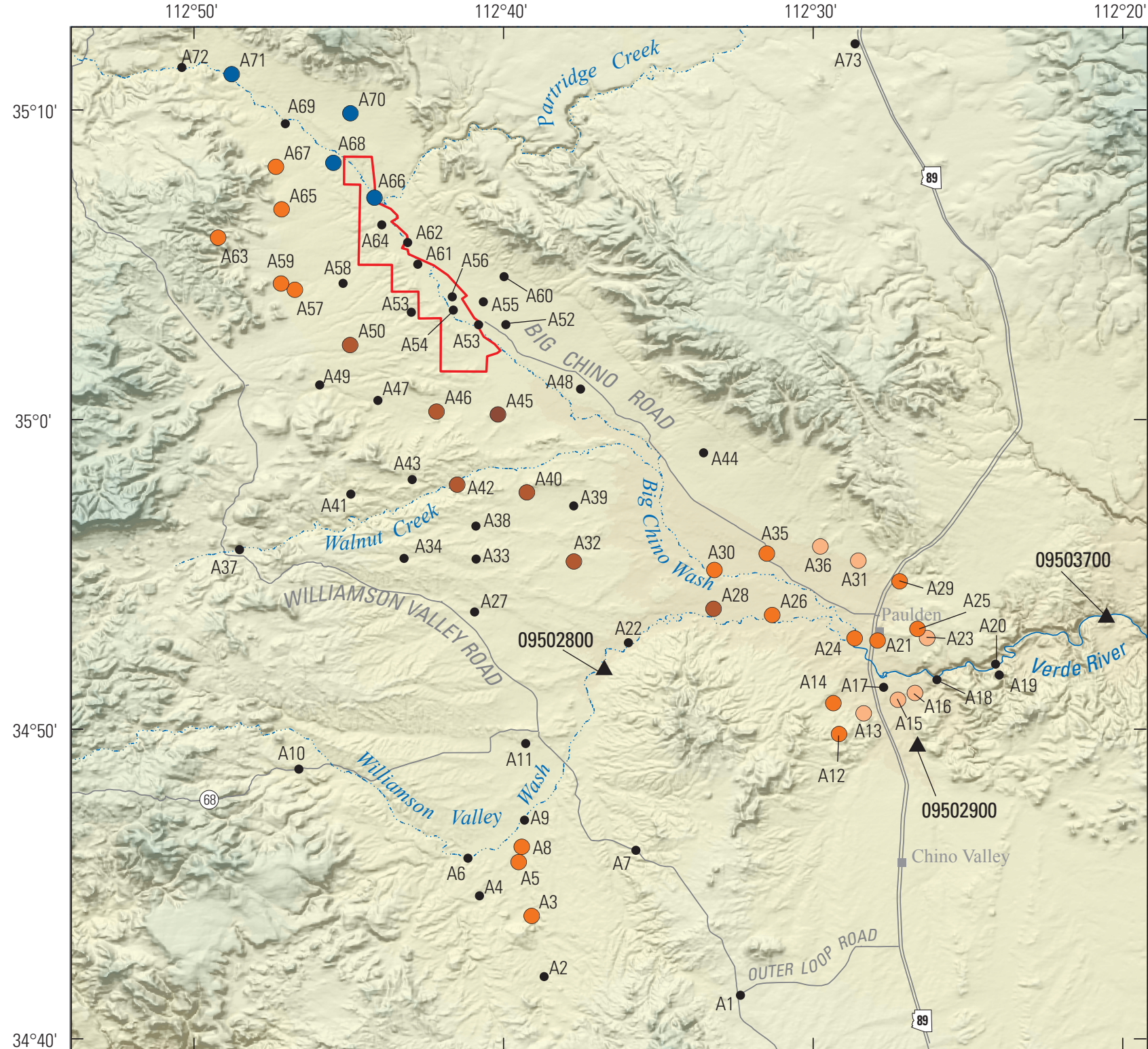

Basemap from USGS

The National Map

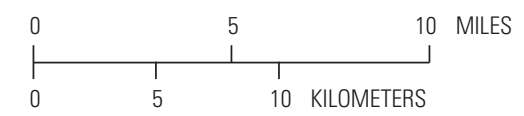

\section{EXPLANATION}

\section{Groundwater-level trend, 2010-2017, in feet per year}

0.01 to 0.50

- -1.49 to -1.00

-0.49 to 0.00

-1.95 to -1.50

-0.99 to -0.50
- No trend in groundwater level

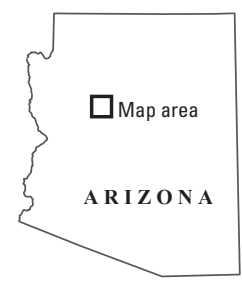

A USGS streamgaging locations

09503700: Verde River Near Paulden, AZ 09502800: Williamson Valley Wash near Paulden, AZ 09502900: Del Rio Springs near Chino Valley, AZ

Big Chino Water Ranch

Figure 17. Map showing significant linear groundwater trends in the Big Chino Subbasin of north-central Arizona, 2010-2017. Trends were identified using the Mann-Kendall trend test. Linear records are those with correlation coefficient greater than 0.75 . See figure 1 for location of map. 


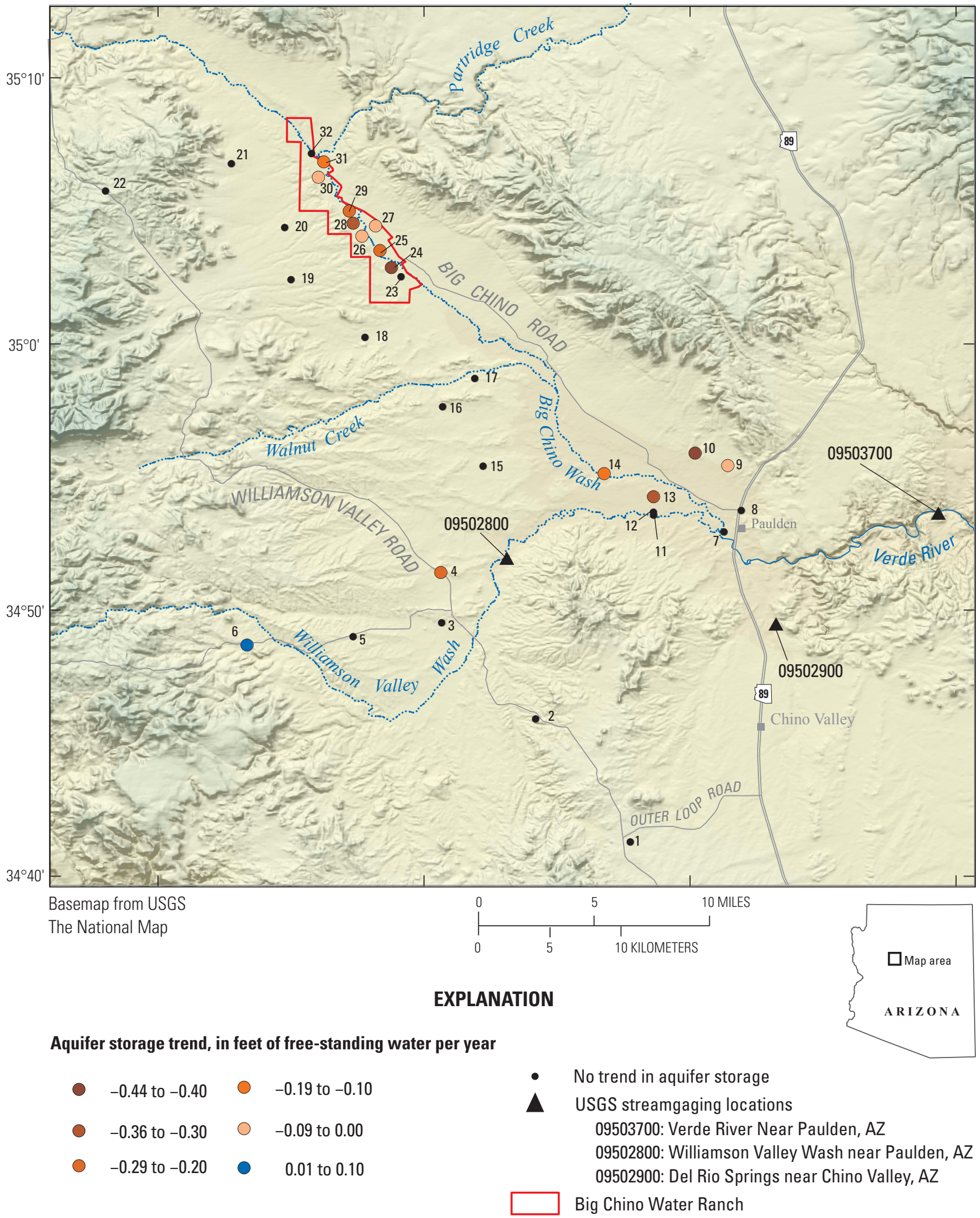

Figure 18. Map showing aquifer-storage trends at repeat microgravity stations in the Big Chino Subbasin of northcentral Arizona. Period of record varies by site. See table 1 for explanation of station numbers. See figure 1 for location of map. 
Table 4. Groundwater wells from the Arizona Department of Water Resources (ADWR) Groundwater Site Inventory database (Arizona Department of Water Resources, 2018) that were analyzed for groundwater trends in the Big Chino Subbasin in north-central Arizona.

[1, Mann-Kendall test for the null hypothesis that no trend exists in the groundwater-level time series was rejected; 0, the null hypothesis was not rejected. --, trend not estimated because it was nonlinear or the Mann-Kendall null hypothesis was not rejected. NAD83, North American Datum of 1983]

\begin{tabular}{|c|c|c|c|c|c|c|}
\hline \multirow{2}{*}{$\begin{array}{c}\text { Station } \\
\text { Key }\end{array}$} & \multirow[b]{2}{*}{ ADWR site number } & \multirow{2}{*}{$\begin{array}{l}\text { Trendline } \\
\text { correlation } \\
\text { coefficient }\end{array}$} & \multirow{2}{*}{$\begin{array}{c}\text { Water table } \\
\text { elevation trend, } \\
\text { in feet per year }\end{array}$} & \multirow{2}{*}{$\begin{array}{l}\text { Mann- } \\
\text { Kendall } \\
\text { trend test }\end{array}$} & \multicolumn{2}{|c|}{ Well location (NAD83) } \\
\hline & & & & & $\begin{array}{c}\text { Latitude, } \\
\text { north }\end{array}$ & $\begin{array}{c}\text { Longitude, } \\
\text { west }\end{array}$ \\
\hline A1 & 344122112322201 & 0.22 & -- & 0 & 32.6898 & 112.5399 \\
\hline $\mathrm{A} 2$ & 344158112384201 & 0.27 & -- & 0 & 32.6998 & 112.6455 \\
\hline $\mathrm{A} 3$ & 344358112390701 & 0.76 & -0.83 & 1 & 32.7327 & 112.6523 \\
\hline A4 & 344435112404301 & 0.34 & -- & 1 & 32.7433 & 112.6804 \\
\hline A5 & 344544112393401 & 0.79 & -0.58 & 1 & 32.7616 & 112.6593 \\
\hline A6 & 344549112410901 & -0.28 & -- & 0 & 32.7636 & 112.6866 \\
\hline A7 & 344604112354301 & -0.05 & -- & 0 & 32.7678 & 112.5962 \\
\hline A8 & 344615112392001 & 0.85 & -0.94 & 1 & 32.7699 & 112.6576 \\
\hline A9 & 344703112392201 & 0.46 & -- & 0 & 32.7841 & 112.6561 \\
\hline A10 & 344841112463701 & 0.13 & -- & 0 & 32.8115 & 112.7776 \\
\hline A11 & 344930112391901 & 0.09 & -- & 0 & 32.8253 & 112.6555 \\
\hline A12 & 344950112291101 & 1.00 & -0.55 & 1 & 32.8305 & 112.4870 \\
\hline A13 & 345030112282301 & 0.99 & -0.43 & 1 & 32.8417 & 112.4737 \\
\hline A14 & 345048112292201 & 1.00 & -0.56 & 1 & 32.8472 & 112.4899 \\
\hline A 15 & 345056112271601 & 0.99 & -0.31 & 1 & 32.8491 & 112.4552 \\
\hline A16 & 345109112264401 & 0.94 & -0.25 & 1 & 32.8527 & 112.4460 \\
\hline A17 & 345120112274301 & 0.41 & -- & 0 & 32.8556 & 112.4628 \\
\hline A 18 & 342600112513401 & -0.18 & -- & 0 & 32.8596 & 112.4341 \\
\hline A19 & 345144112235901 & 0.20 & -- & 0 & 32.8622 & 112.4005 \\
\hline A20 & 345205112240601 & 0.10 & -- & 0 & 32.8680 & 112.4025 \\
\hline A21 & 345302112275601 & 0.91 & -0.52 & 1 & 32.8809 & 112.4662 \\
\hline $\mathrm{A} 22$ & 345255112261901 & -0.20 & -- & 0 & 32.8796 & 112.6002 \\
\hline A23 & 345256112261901 & 0.87 & -0.30 & 1 & 32.8823 & 112.4395 \\
\hline A 24 & 345300112283701 & 0.95 & -0.55 & 1 & 32.8821 & 112.4785 \\
\hline A25 & 345314112263801 & 0.92 & -0.58 & 1 & 32.8872 & 112.4447 \\
\hline A26 & 345338112311801 & 0.98 & -0.76 & 1 & 32.8946 & 112.5229 \\
\hline $\mathrm{A} 27$ & 345347112405801 & -0.58 & -- & 1 & 32.8961 & 112.6830 \\
\hline A28 & 345353112331301 & 0.88 & -1.02 & 1 & 32.8980 & 112.5544 \\
\hline A29 & 345449112271101 & 0.90 & -0.63 & 1 & 32.9128 & 112.4542 \\
\hline $\mathrm{A} 30$ & 345507112330901 & 0.91 & -0.97 & 1 & 32.9189 & 112.5540 \\
\hline A 31 & 345528112283201 & 0.98 & -0.46 & 1 & 32.9239 & 112.4765 \\
\hline A 32 & 345524112374401 & 1.00 & -1.05 & 1 & 32.9234 & 112.6296 \\
\hline A33 & 345530112405501 & 0.18 & -- & 0 & 32.9246 & 112.6822 \\
\hline A 34 & 345533112431001 & 0.47 & -- & 0 & 32.9250 & 112.7210 \\
\hline A 35 & 345542112312801 & 0.84 & -0.66 & 1 & 32.9277 & 112.5257 \\
\hline A36 & 345557112294501 & 0.93 & -0.33 & 1 & 32.9316 & 112.4969 \\
\hline A 37 & 345548112483101 & -0.06 & -- & 0 & 32.9297 & 112.8096 \\
\hline
\end{tabular}


Table 4. Groundwater wells from the Arizona Department of Water Resources (ADWR) Groundwater Site Inventory database (Arizona Department of Water Resources, 2018) that were analyzed for groundwater trends in the Big Chino Subbasin in north-central Arizona.Continued

[1, Mann-Kendall test for the null hypothesis that no trend exists in the groundwater-level time series was rejected; 0 , the null hypothesis was not rejected. --, trend not estimated because it was nonlinear or the Mann-Kendall null hypothesis was not rejected. NAD83, North American Datum of 1983]

\begin{tabular}{|c|c|c|c|c|c|c|}
\hline \multirow{2}{*}{$\begin{array}{c}\text { Station } \\
\text { Key }\end{array}$} & \multirow[b]{2}{*}{ ADWR site number } & \multirow{2}{*}{$\begin{array}{l}\text { Trendline } \\
\text { correlation } \\
\text { coefficient }\end{array}$} & \multirow{2}{*}{$\begin{array}{l}\text { Water table } \\
\text { elevation trend, } \\
\text { in feet per year }\end{array}$} & \multirow{2}{*}{$\begin{array}{l}\text { Mann- } \\
\text { Kendall } \\
\text { trend test }\end{array}$} & \multicolumn{2}{|c|}{ Well location (NAD83) } \\
\hline & & & & & $\begin{array}{c}\text { Latitude, } \\
\text { north }\end{array}$ & $\begin{array}{c}\text { Longitude, } \\
\text { west }\end{array}$ \\
\hline A38 & 345629112405201 & 0.73 & -- & 1 & 32.9424 & 112.6823 \\
\hline A39 & 345712112374501 & 0.53 & -- & 1 & 32.9532 & 112.6296 \\
\hline A 40 & 345738112391501 & 1.00 & -1.01 & 1 & 32.9606 & 112.6549 \\
\hline A 41 & 345734112445501 & 0.29 & -- & 0 & 32.9596 & 112.7496 \\
\hline A 42 & 345755112413201 & 0.98 & -1.26 & 1 & 32.9648 & 112.6925 \\
\hline $\mathrm{A} 43$ & 345804112425701 & 0.24 & -- & 0 & 32.9674 & 112.7166 \\
\hline A44 & 345856112333201 & 0.34 & -- & 0 & 32.9818 & 112.5597 \\
\hline A 45 & 350009112401201 & 0.89 & -1.72 & 1 & 32.0026 & 112.6705 \\
\hline A 46 & 350016112421001 & 0.98 & -1.05 & 1 & 32.0042 & 112.7035 \\
\hline A47 & 350037112440301 & 0.65 & -- & 0 & 32.0100 & 112.7350 \\
\hline A 48 & 350059112373101 & 0.27 & -- & 0 & 32.0161 & 112.6260 \\
\hline A49 & 350111112455601 & 0.99 & -1.95 & 1 & 32.0183 & 112.7664 \\
\hline A50 & 350224112445801 & 0.98 & -1.18 & 1 & 32.0400 & 112.7500 \\
\hline A51 & 350303112395601 & 0.01 & -- & 0 & 32.0508 & 112.6662 \\
\hline A52 & 350302112404801 & 0.36 & -- & 0 & 32.0507 & 112.6809 \\
\hline A53 & 350327112425901 & 0.19 & -- & 0 & 32.0575 & 112.7170 \\
\hline A54 & 350332112413701 & -0.17 & -- & 0 & 32.0586 & 112.6945 \\
\hline A55 & 350341112403901 & 0.13 & -- & 0 & 32.0631 & 112.6783 \\
\hline A56 & 350356112413901 & -0.04 & -- & 0 & 32.0658 & 112.6950 \\
\hline A57 & 350410112464401 & 0.99 & -0.74 & 1 & 32.0697 & 112.7798 \\
\hline A58 & 350423112451101 & -0.40 & -- & 0 & 32.0730 & 112.7538 \\
\hline A59 & 350423112471201 & 1.00 & -0.95 & 1 & 32.0731 & 112.7874 \\
\hline A 60 & 350436112395901 & -0.68 & -- & 1 & 32.0766 & 112.6671 \\
\hline A61 & 350500112424601 & 0.07 & -- & 0 & 32.0833 & 112.7136 \\
\hline A62 & 350535112432701 & 0.04 & -- & 0 & 32.0950 & 112.7190 \\
\hline A63 & 350551112491301 & 0.88 & -0.82 & 1 & 32.0978 & 112.8211 \\
\hline A64 & 350616112435601 & -0.67 & -- & 1 & 32.1045 & 112.7330 \\
\hline A65 & 350647112471101 & 0.99 & -0.94 & 1 & 32.1130 & 112.7871 \\
\hline A66 & 350709112441101 & -0.92 & 0.29 & 1 & 32.1194 & 112.7370 \\
\hline A67 & 350805112471801 & 1.00 & -0.90 & 1 & 32.1359 & 112.7901 \\
\hline A68 & 350814112452701 & -0.86 & 0.17 & 1 & 32.1381 & 112.7592 \\
\hline A69 & 350932112470301 & 0.52 & -- & 1 & 32.1589 & 112.7849 \\
\hline A70 & 350953112445701 & -0.92 & 0.25 & 1 & 32.1648 & 112.7499 \\
\hline A71 & 351130112482401 & -0.88 & 0.20 & 1 & 32.1859 & 112.8139 \\
\hline A72 & 351120112502401 & -0.30 & -- & 0 & 32.1892 & 112.8406 \\
\hline A73 & 351207112283701 & 0.07 & -- & 0 & 32.2020 & 112.4782 \\
\hline
\end{tabular}




\section{Summary and Conclusions}

This report summarizes changes in groundwater storage and trends in groundwater levels in the southern part of the Big Chino groundwater subbasin during the 2010-2017 period, provides estimates of confined or unconfined aquifer conditions at monitored locations, and where possible, provides estimates of specific yield. Data in the report indicated small declines in groundwater storage throughout the study area, owing to domestic and agricultural pumping and minimal recharge. Significant recharge events caused by periods of sustained precipitation were absent during the study period; the most recent major recharge event in the subbasin occurred during winter 2004-2005. Data in the report reinforces the idea that land-surface recharge in semiarid environments is negligible and most recharge happens during occasional periods of higher than average rainfall and runoff (French and others, 1996; Izbicki and others, 2000).

During the 2010-2017 period, groundwater levels declined most rapidly in the upland area to the west of Big Chino Wash. The highest rates of decline were near the center of the study area around Walnut Creek, with smaller declines near the northern and southern extents. Groundwater-level declines were also widespread in the Paulden area and to a lesser extent in the Williamson Valley Wash area. Groundwater levels at most wells in the Paulden area declined between about 0.25 and $1.0 \mathrm{ft} / \mathrm{yr}$. In the northernmost part of the BCWR area, groundwater levels rose slightly, about $0.25 \mathrm{ft} / \mathrm{yr}$. Other wells in the BCWR showed no long-term trend and (or) fluctuate in response to local pumping (that is, groundwater levels fall during periods of withdrawals for irrigation, and rise during the rest of the year). Groundwater-level trends to the north and east of the study area are largely unknown owing to the lack of monitoring wells in the area. Because pumping creates a transient response that propagates through an aquifer, potentially over a period of decades to centuries (Barlow and Leake, 2012), present-day groundwater-level changes may reflect historical pumpage dating to the 1950s or earlier and changes in pumpage over time.

Aquifer-storage-change estimates from repeat microgravity also show declines in groundwater storage in many areas. In the area west of Big Chino Wash, where many wells show groundwater-level declines, there is no apparent trend in storage. However, many stations in this area have short records (1 year), and trends may not yet be apparent. In the BCWR area, where most wells show no trend and (or) are nonlinear, most stations indicated declining aquifer storage. Of note, the two datasets are not contradictory (that is, one dataset is not indicating an increase in storage where the other indicates a decrease) but merely do not reinforce each other (where one dataset indicates a decrease, the other is inconclusive). Both water-level and gravity datasets indicate an overall decrease in aquifer storage throughout the study area, except for the northernmost part of the BCWR and possibly in the foothills of the Santa Maria and Juniper Mountains.

Confined or semiconfined aquifer conditions appear to exist throughout the study area except for possibly the
Williamson Valley Wash area. Most wells monitored for this report were screened in deeper, confined or semiconfined aquifer units. Driller's logs in the Paulden area, the area west of Big Chino Wash, and the BCWR area all indicate varied grain size within the basin fill, and clay intervals at various depths are common. Although there is likely an uppermost unconfined aquifer unit throughout the study area, there is very little waterlevel monitoring of this aquifer. The only well in the present study known to monitor the unconfined aquifer is B-18-02 $31 \mathrm{BCB}$ (station 13) in the Paulden area, screened from 15 to $320 \mathrm{ft}$ below land surface. The unconfined aquifer in the Paulden area is likely connected to some degree with the deeper confined or semiconfined aquifer(s), as indicated by water-level changes in the deeper confined or semiconfined aquifer(s) in response to runoff in 2004-2005. Better water-level monitoring in the unconfined aquifer in the Paulden area and elsewhere would help define the hydraulic connection between aquifers. Similarly, the aquifer within the Redwall and (or) Muav Limestone units underneath basin fill in the Big Chino Valley are largely unmonitored and the connection with shallower basinfill aquifers is unknown.

No especially wet years (such as winter 2004-2005) occurred during the study period, making it difficult to assess the importance of channel recharge and, more generally, the effect of climate on recharge. Based on steady and (or) falling groundwater levels, it appears that few or no discrete channelrecharge events occurred even during relatively wet years during the study period (there was likely relatively steady recharge from precipitation at higher elevations in the Big Chino Subbasin; some recharge is required to maintain steady groundwater levels if groundwater is removed by pumping or discharged to base flow). The wettest periods, such as winter 2017, were at or only slightly above climatological averages for rainfall (10.2-12.2 inches per year for the 1982-2010 period at the Big Chino Water Ranch, Paulden, and Chino Valley precipitation stations; PRISM Climate Group, 2018). Relatively large flows in Big Chino Wash and lower Williamson Valley Wash occurred in 2017, which are normally dry except in response to rainfall. However, these flows did not cause an increase in groundwater levels.

The importance of a thick clay unit in the center of Big Chino Valley to groundwater flow cannot be evaluated directly from the data in this report, mostly because there are few stations in the vicinity. However, groundwater trends in the Paulden and BCWR areas are clearly different, and BCWR wells are more poorly correlated with climate, as compared to the Paulden area wells. The clay unit may or may not delay the effects of groundwater pumping in the upper part of the basin from discharge (both pumping and base flow) in the lower part of the subbasin, and the time scale for pumping at BCWR to affect base flow in the Verde River is unknown. On the other hand, boreholes have penetrated coarse-grained material underlying the clay unit, at least in some locations (Wirt and others, 2005). To better understand the connection between the upper and lower parts of the basin-fill aquifer in Big Chino Valley, continuous groundwater-level monitoring in monitoring wells or piezometers closer to, and within, the clay unit is suggested. 
Repeat microgravity data collected during the study provide useful but not definitive information about aquifer confining conditions and storage properties. The shortcoming lies in the signal-to-noise ratio in the data. Because storage changes during the study period were minor, owing to the lack of significant recharge events and minimal pumping, the signal measured using repeat microgravity was correspondingly small. At the same time, noise in the measurements was relatively high. In part this was because gravity stations were constructed to be minimally invasive, without installing large concrete measurement platforms. The result is possible vertical movement not captured by Global Positioning System surveys and greater sensitivity to soil moisture (at stations on concrete platforms, soil-moisture changes are generally smaller because there is less infiltration). Also, insufficient field soil-moisture data were collected to correct every measurement at every station, thus the reliance on satellite data for soil moisture correction. The dataset presented in this report was the largest absolutegravity dataset collected for a hydrology study to date and represents ongoing research into improvements for the application of gravity methods to independently determine storage changes in unconfined groundwater systems.

Another challenge with the present study arose from the need to repurpose pumping wells as observation wells. Many of the wells used in the study were drilled in the 1950s or earlier, and construction details are sparse. Most were constructed with long screened intervals (100 ft or more) to admit the maximum amount of water to the well. When used as monitoring wells, they provide the average hydraulic head over the length of the screened interval. Because the well screens likely cross multiple aquifer units, potentially confined and unconfined, the groundwater-level measurements may not represent any one unit. Therefore, it is difficult to compare groundwater levels among wells (for example, to calculate gradients), as even two wells close together may not be in hydraulic communication owing to construction and screened-interval differences. Monitoring specific aquifer units would be improved by constructing wells specifically for monitoring, with short screened intervals, ideally with multiple nested wells in a single location with screened intervals at varying depths. This would provide better information about vertical hydraulic gradients and the existence or absence of confining conditions.

This study supports previous reports that indicate the aquifer system in the southern part of the Big Chino Subbasin is more complex than a single, unconfined aquifer (Wirt and others, 2005). Relatively large storage changes in the Williamson Valley Wash area, the Paulden area, and the area west of Big Chino Wash that are uncorrelated with groundwater-level changes indicated that there can be significant changes in storage above the aquifer monitored by a particular well, either in the unsaturated zone (where water is stored as soil moisture), or in aquifers not in hydraulic communication with wells used to monitor water level. On the other hand, minimal changes in storage in the BCWR area indicate the unsaturated zone has relatively low storage capacity. Measurements showing little storage change, and the rapid propagation of hydraulic response throughout the aquifer, point to confining conditions in much of the Paulden area, the area west of Big Chino Wash, and the BCWR area. In the Paulden area, based on historical groundwater and Verde River base-flow data, the effect of additional pumping would likely propagate relatively quickly through the aquifer and reduce groundwater discharge to the river. In the BCWR area, the effect of additional pumping is less clear, but basic hydrologic principles described by Barlow and Leake (2012) indicate the eventual capture of (reduction of discharge to) groundwater discharge to surface water, evapotranspiration, or subflow to adjacent groundwater basins.

\section{References Cited}

Albergel, C., Rüdiger, C., Pellarin, T., Calvet, J.- C., Fritz, N., Froissard, F., Suquia, D., Petitpa, A., Piguet, B., and Martin, E., 2008, From near-surface to root-zone soil moisture using an exponential filter: an assessment of the method based on in-situ observations and model simulations: Hydrological and Earth System Science., vol. 12, p. 1323-1337.

Arizona Corporation Commission, 2018, Water company annual reports: Arizona Corporation Commission website, accessed April 9, 2018, at http://www.azcc.gov/Divisions/ Utilities/Annual\%20Reports/water.asp.

Arizona Department of Water Resources, 2000, Verde River watershed study: Phoenix, Arizona, Arizona Department of Water Resources, $497 \mathrm{p}$.

Arizona Department of Water Resources, 2010, Arizona water atlas, volume 5-Central Highlands Panning Area: Arizona Department of Water Resources, 90 p, accessed April 9 , 2018, at http://www.azwater.gov/AzDWR/StatewidePlanning/WaterAtlas/CentralHighlands/documents/Volume_5_ Final.pdf.

Arizona Department of Water Resources, 2018, Groundwater site inventory: Arizona Department of Water Resources website, accessed April 9, 2018, at https://gisweb.azwater. gov/waterresourcedata/gwsi.aspx.

Arizona Office of Administrative Hearings, [2019], Electronic case file, 08A-AWS001-DWR, City of Prescott, Arizona: Arizona Office of Administrative Hearings web page, accessed April, 16. 2019, at https://portal.azoah.com/oedf/ documents/08A-AWS001-DWR/.

Barlow, P.M., and Leake, S.A., 2012, Streamflow depletion by wells-Understanding and managing the effects of groundwater pumping on streamflow: U.S. Geological Survey Circular 1376, 84 p. [Also available at http://pubs.usgs.gov/ circ/1376/.] 
Blasch, K.W., Hoffmann, J.P., Graser, L.F., Bryson, J.R., and Flint, A.L., 2006, Hydrogeology of the upper and middle Verde River watersheds, central Arizona: U.S. Geological Survey Scientific Investigations Report 2005-5198, 102 p., 3 plates. [Also available at https://pubs.usgs.gov/ $\operatorname{sir} / 2005 / 5198 /$.

Clear Creek and Associates, 2008, Summary report-Hydrologic study of the CV Ranch, Big Chino Valley, Yavapai County, Arizona: Clear Creek and Associates, LLC, report, 2 volumes.

Copernicus Service information, 2017, Soil water index: Copernicus Service information website, accessed November 5, 2017, at https://land.copernicus.eu/global/products/ swi.

Corona, C.R., Gurdak, J.J., Dickinson, J.E., Ferré, T.P.A., and Maurer, E.P., 2018, Climate variability and vadose zone controls on damping of transient recharge: Journal of Hydrology, v. 561, p. 1094-1104.

Creutzfeldt, B., Güntner, A., Wziontek, H., and Merz, B., 2010, Reducing local hydrology from high-precision gravity measurements - A lysimeter-based approach: Geophysical Journal International, v. 183, no. 1, 178-187, https://doi. org/10.1111/j.1365-246X.2010.04742.x.

DeWitt, E., Langenheim, V., Force, E., Vance, R.K., Lindberg, P.A., and Driscoll, R.L., 2008, Geologic map of the Prescott National Forest and the headwaters of the Verde River, Yavapai and Coconino Counties, Arizona: U.S. Geological Survey Scientific Investigations Map 2996, scale 1:100,000, 100-p. pamphlet. [Also available at https://pubs.usgs.gov/ $\operatorname{sim} / 2996 /$.

Dickens, J.M., Forbes, B.T., Cobean, D.S., and Tadayon, Saeid, 2011, Documentation of methods and inventory of irrigation data collected for the 2000 and 2005 U.S. Geological Survey estimated use of water in the United States, comparison of USGS-compiled irrigation data to other sources, and recommendations for future compilations: U.S. Geological Survey Scientific Investigations Report 2011-5166, 60 p. [Also available at https://pubs.usgs.gov/ $\operatorname{sir} / 2011 / 5166 /$.

Errol L. Montgomery and Associates, Inc., 2007, Draft review of 2005 and 2006 USGS reports on Verde River Watershed: Errol L. Montgomery and Associates, Inc., draft report, 62 p., accessed April 16, 2019, at https://portal.azoah. com/oedf/documents/08A-AWS001-DWR/Supplemental Prescott/Prescott\%20510\%20McGavockReviewofUSGSRe ports(DraftReport).pdf.

Euge, K.M., Schell, B.A., and Lam, I.P., 1992, Development of seismic acceleration maps for Arizona: Arizona Department of Transportation Report AZ92-344, 327 p., 5 sheets, scale 1:1,000,000.
Ewing, D.B., Osterberg, J.C., and Talbot, W.R., 1994, Groundwater study of the Big Chino Valley-Technical report, section I of III, perspective: U.S. Bureau of Reclamation, 8 p.

Flora, S., Davis, T., and Corkhill, F., 2009, Water level changes in Big Chino Sub-basin, Arizona: Arizona Department of Water Resources Water Level Change Map Series, no. $4 ., 3$ sheets.

French, R.H., Jacobson, R.L., and Lyles, B.F., 1996, Threshold precipitation events and potential ground-water recharge: Journal of Hydraulic Engineering, v. 122, no. 10, p. $573-$ 578.

Helsel, D.R., and Hirsch, R.M., 2002, Statistical Methods in Water Resources: U.S. Geological Survey Techniques of Water Resources Investigations, Book 4, chapter A3, 522 p. [Also available at https://pubs.usgs.gov/twri/twri4a3/.]

Izbicki, J.A., Radyk, J., and Michel, R.L., 2000, Water movement through a thick unsaturated zone underlying an intermittent stream in the western Mojave Desert, southern California, USA: Journal of Hydrology, v. 238, no. 3-4, p. 194-217.

Kennedy, J.R., Kahler, L.M., and Pool, D.R., 2019, Repeat microgravity data from the Big Chino Subbasin, Yavapai County, Arizona: U.S. Geological Survey data release, https://doi.org/10.5066/P9S40E4D.

Kennedy, J.R., Ferré, T.P.A., Guntner, A., Abe, M., Creutzfeldt, B., and Güntner, A., 2014, Direct measurement of subsurface mass change using the variable baseline gravity gradient method: Geophysical Research Letters, v. 41, no. 8, p. 2827-2834, https://doi. org/10.1002/2014GL059673.

Langenheim, V.E., DeWitt, Ed, and Wirt, Laurie, 2005, Preliminary geophysical framework of the upper and middle Verde River watershed, Yavapai County, Arizona: U.S. Geological Survey Open-File Report 2005-1154, 43 p. [Also available at https://pubs.usgs.gov/of/2005/1154/.]

Macy, J.P., and Heilman, J.A., 2018, Controlled source audio-frequency magnetotellurics (CSAMT) data from the Big Chino Wash and Paulden areas, Yavapai County, Arizona: U.S. Geological Survey data release, https://doi. org/10.5066/P9KGKWNL.

Meyer, R.R., 1963, A chart relating well diameter, specific capacity, and the coefficients of transmissibility and storage: U.S. Geological Survey Water Supply Paper 1963-I, p. 338-341.

Nathan, R.J., and McMahon, T.A., 1990, Evaluation of automated techniques for base flow and recession analysis: Water Resources Research, v. 26, p. 1465-1473, 1990.

National Geodetic Survey, 2018, OPUS-Online positioning user service: National Geodetic Survey website, accessed March 10, 2018, at https://www.ngs.noaa.gov/OPUS. 
National Oceanic and Atmospheric Administration, 2018, Climate data online-Daily summaries: National Oceanic and Atmospheric Administration, National Centers for Environmental Information, online database, accessed multiple dates, last accessed October 2, 2018, at https://www.ncdc. noaa.gov/cdo-web/datasets.

Navarro, L.F., 2002, Characterization and ground-water flow modeling of the Mint Wash/Williamson Valley area, Yavapai County: Northern Arizona University, M.S. thesis, $174 \mathrm{p}$.

Ostenaa, D.A., Schmischal, U., King, C.E., Jr., and Wright, J.W., 1993, Big Chino Valley groundwater study-Geologic framework investigations: Denver, Colo., Bureau of Reclamation Seismotectonic Report 93-2, v. 1, 31 p., v. 2, 9 plates and appendixes.

Owen-Joyce, S.J., and Bell, C.K., 1983, Appraisal of water resources in the upper Verde River area, Yavapai and Coconino Counties, Arizona: Arizona Department of Water Resources Bulletin 2, $219 \mathrm{p}$.

Pool, D.R., 2008, The utility of gravity and water-level monitoring at alluvial aquifer wells in southern Arizona: Geophysics, v. 73, no. 6, p. WA49-WA59, https://doi. org/10.1190/1.2980395.

Pool, D.R., and Anderson, M.T., 2008, Ground-water storage change and land subsidence in Tucson Basin and Avra Valley, southeastern Arizona, 1998-2002: U.S. Geological Survey Scientific Investigations Report 2007-5275, 34 p., accessed February 1, 2018, at https://pubs.usgs.gov/ $\operatorname{sir} / 2007 / 5275$.

Pool, D.R., and Eychaner, J.H., 1995, Measurements of Aquifer-storage change and specific yield using gravity surveys: Ground Water, v. 33, no. 3, p. 425-432.

Pool, D.R., Blasch, K.W., Callegary, J.B., Leake, S.A., and Graser, L.F., 2011, Regional groundwater-flow model of the Redwall-Muav, Coconino, and alluvial basin aquifer systems of northern and central Arizona: U.S. Geological Survey Scientific Investigations Report 2010-5180, ver. 1.1, 101 p., accessed March 20, 2018, at https://pubs.usgs.gov/ $\operatorname{sir} / 2010 / 5180$.

Pope, G.L., Rigas, P.D., and Smith, C.F., 1998, Statistical summaries of streamflow data and characteristics of drainage basins for selected streamflow-gauging stations in Arizona through Water Year 1996: U.S. Geological Survey WaterResources Investigations Report 98-4225, 907 p. [Also available at https://pubs.er.usgs.gov/publication/wri984225.]

PRISM Climate Group, 2018, PRISM climate data: Oregon State University website, accessed February 4, 2018, at http://prism.oregonstate.edu.
Reichle, R., De Lannoy, G., Koster, R.D., Crow, W.T., and Kimball, J.S., 2017, SMAP L4 9 km EASE-Grid surface and root zone soil moisture analysis update, version 3: National Aeronautics and Space Administration, National Snow and Ice Data Center, online database, https://doi. org/10.5067/20ULJH6EZKFJ.

Schmerge, D., and Francis, O., 2006, Set standard deviation, repeatability and offset of absolute gravimeter A10008: Metrologia, v. 43, no. 5, p. 414-418, https://doi. org/10.1088/0026-1394/43/5/012.

Schwab, K.J., 1995, Maps showing groundwater conditions in the Big Chino sub-basin of the Verde River Basin, Coconino and Yavapai Counties, Arizona-1992: Arizona Department of Water Resources Hydrologic Map Series Report no. 28, scale 1:250,000.

Scott, R.L., Shuttleworth, W.J., Keefer, T.O., and Warrick, A.W., 2000, Modeling multiyear observations of soil moisture recharge in the semiarid American Southwest: Water Resources Research, v. 36, no. 8, p. 2233-2247, https://doi. org/10.1029/2000WR900116.

Sloto, R.A., and Crouse, M.Y., 1996, HYSEP-A computer program for streamflow hydrograph separation and analysis: U.S. Geological Survey Water-Resources Investigations Report 1996-4040, 46 p. [Also available at https://pubs. er.usgs.gov/publication/wri964040.]

Soule, C.H., 1978, Tectonic geomorphology of the Big Chino fault, Yavapai County, Arizona: Tucson, University of Arizona, M.S. thesis, 114 p.

Southwest Groundwater Consultants, Inc., 2007, Hydrology report Big Chino Water Ranch (BCWR) in support of modification of designation of assured water supply: Southwest Groundwater Consultants, Inc., report, 89 p.

Tadayon, S., 2005, Water withdrawals for irrigation, municipal, mining, thermoelectric-power, and drainage uses in Arizona outside of active management areas, 1991-2000: U.S. Geological Survey Scientific Investigations Report 2004-5293, 28 p., accessed January 12, 2018, at https:// pubs.usgs.gov/sir/2004/5293/.

Theis, C.V., 1963, Estimating the transmissivity of a watertable aquifer from the specific capacity of a well: U.S. Geological Survey Water Supply Paper 1536-I, p. 332-336.

Torge, W., 1989, Gravimetry: Berlin, Germany, De Gruyter, $482 \mathrm{p}$.

U.S. Census Bureau, 2018, American FactFinder: U.S. Census Bureau website, accessed May 15, 2018, at https://factfinder.census.gov/faces/nav/jsf/pages/index.xhtml. 
U.S. Geological Survey, 2018, StreamStats v4.2.1: U.S. Geological Survey web-based application, accessed September 28, 2018, at https://streamstats.usgs.gov/ss.

Wallace, B.L., and Laney, R.L., 1976, Maps showing groundwater conditions in the lower Big Chino Valley and Williamson Valley areas, Yavapai and Coconino Counties, Arizona-1975-76: U.S. Geological Survey Water-Resources Investigations Report 76-78, 2 sheets.

Water Resources Associates, 1990, Hydrogeology investigation of Big Chino Valley, Yavapai County, Arizona: Phase II, Water Resources Associates consultant report for City of Prescott, City Attorney's Office, Prescott, Arizona, February 5, 1990, 3 vols.

White, N., 1965, Annual report on ground water in ArizonaSpring 1964 to Spring 1965: Arizona State Land Department, Water-Resources Report 24, 63 p.

Wilson, E.D., and Moore, R.T., 1959, Structure of Basin and Range province in Arizona, in Heindl, L.A., ed., Southern Arizona Guidebook II: Tucson, Arizona Geological Society, p. 89-97.
Wilson, R.P, 1991, Summary of ground-water conditions in Arizona 1985-86: U.S. Geological Survey Water-Resources Investigation Report 90-4179, 4 sheets.

Wirt, Laurie, and Hjalmarson, H.W., 2000, Sources of springs supplying base flow to the Verde River headwaters, Yavapai County, Arizona: U.S. Geological Survey Open-File Report 99-0378, 50 p., accessed April 13, 2018, at https://pubs. usgs.gov/of/1999/ofr-99-0378/.

Wirt, Laurie, DeWitt, Ed, and Langenheim, V.E., 2005, Geologic framework of aquifer units and ground-water flowpaths, Verde River headwaters, north-central Arizona: U.S. Geological Survey Open-File Report 2004-1411, accessed April 13, 2018, at https://pubs.usgs.gov/of/2004/1411/.

Yavapai County Flood Control District, 2018, Precipitation values: Yavapai County Flood Control District online database, accessed multiple dates, last accessed April 27, 2018, at http://gis.yavapai.us/alert/pgi.aspx.
Menlo Park Publishing Service Center, California Manuscript approved for publication June 18, 2019 Edited by James W. Hendley II Layout and design by Kimber Petersen 
政

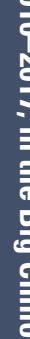

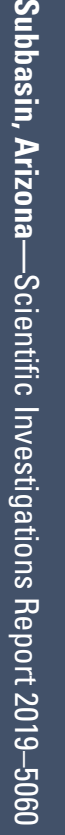

ISSN 2328-0328 (online) 